\title{
MicroRNA Signature in Melanoma: Biomarkers and Therapeutic Targets
}

\author{
Soudeh Ghafouri-Fard ${ }^{1}$, Mahdi Gholipour ${ }^{1}$ and Mohammad Taheri ${ }^{2 *}$ \\ ${ }^{1}$ Department of Medical Genetics, Shahid Beheshti University of Medical Sciences, Tehran, Iran, ${ }^{2}$ Urology and Nephrology \\ Research Center, Shahid Beheshti University of Medical Sciences, Tehran, Iran
}

Melanoma is the utmost fatal kind of skin neoplasms. Molecular changes occurring during the pathogenic processes of initiation and progression of melanoma are diverse and include activating mutations in BRAF and NRAS genes, hyper-activation of PI3K/AKT pathway, inactivation of p53 and alterations in CDK4/CDKN2A axis. Moreover, several miRNAs have been identified to be implicated in the biology of melanoma through modulation of expression of genes being involved in these pathways. In the current review, we provide a summary of the bulk of information about the role of miRNAs in the pathobiology of melanoma, their possible application as biomarkers and their emerging role as therapeutic targets for this kind of skin cancer.

\section{OPEN ACCESS}

Edited by:

Giuseppe Palmieri,

National Research Council (CNR), Italy

Reviewed by:

Georg Wondrak,

University of Arizona, United States

Eva Hernando,

New York University, United States

${ }^{*}$ Correspondence:

Mohammad Taher mohammad_823@yahoo.com

Specialty section:

This article was submitted to Skin Cancer,

a section of the journal

Frontiers in Oncology

Received: 22 September 2020 Accepted: 30 March 2021 Published: 22 April 2021

Citation: Ghafouri-Fard S, Gholipour M and Taheri M (2021) MicroRNA Signature in Melanoma: Biomarkers and Therapeutic Targets.

Front. Oncol. 11:608987. doi: 10.3389/fonc.2021.608987
Keywords: miRNA, melanoma, biomarker, expression, polymorphism

\section{INTRODUCTION}

Arising from unrestrained proliferation of melanocytes, melanoma is the utmost fatal kind of skin neoplasm (1). Though melanoma encompasses less than $5 \%$ of all skin cancers, it accounts for most of skin neoplasms mortalities (2). When the cancer is diagnosed in early stages, surgical resection of the tumor is the appropriate therapeutic options for enhancement of survival of patients. Yet, based on the metastatic potential of melanoma, surgery is not satisfactory in advanced stages of melanoma (3). Although the mortality rate of primary melanoma is about $11 \%$, metastatic melanoma has a poor prognosis resulting from inefficiency of conventional therapies $(4,5)$. Meanwhile, novel therapeutic option might offer efficient methods for these patients. For instance, immunotherapeutic approaches such as administration of Anti-PD1 (nivolumab, pembrolizumab) alone, or the combination of anti-PD1 with anti-cytotoxic $\mathrm{T}$ lymphocyteassociated protein 4 (CTLA4) ipilimumab has raised the survival of patients who suffer from advanced stages of melanoma (6).

Targeted therapies, like combinations of BRAF inhibitors (Dabrafenib) and MEK inhibitors (vemurafenib) are also frequently used on BRAFV600E mutant melanomas. Superficial spreading, nodular, lentigo maligna and acral lentiginous melanomas represent the main types of melanoma with the first one being the most frequent type (4). Ultraviolet radiation and melanocytic nevi are two main risk factors for development of this kind of skin cancer (4). Molecular changes occurring during the pathogenic processes of initiation and progression of melanoma are diverse and include activating mutations in BRAF and NRAS genes, hyper-activation of PI3K/AKT pathway, inactivation of p53 and alterations in CDK4/CDKN2A axis (4). In addition, several studies have shown the critical role of microRNAs (miRNAs) both in the initiation and in the progression of melanoma (7). These transcripts have sizes around 22 nucleotides and are generated through a 
multi-step process from DNA sequences into primary, precursor and mature miRNAs, respectively. As a general rule, they regulate gene expression through binding with complementary sequences in the $3^{\prime}$ untranslated region ( $3^{\prime}$ UTR) of mRNAs and subsequently lead to degradation and suppression of translation of the target transcript. Less frequently, they interact with the $5^{\prime}$ UTR, coding or promoter regions (8). Moreover, there are some reports of activation of translation of certain genes by miRNAs in some situations. For instance, let-7 family of miRNAs can induce translation when cell cycle is arrested in spite of their inhibitory effects on translation during cell proliferation (9). Therefore, miRNAs are regarded as important mediators of gene expression. Besides, their presence in extracellular vesicles provides them the opportunity to module communication between various cells (8). In the current paper, we summarize the bulk of information about the role of miRNAs in the pathobiology of melanoma, their possible application as biomarkers and their emerging role as therapeutic targets for this kind of skin cancer.

\section{DYSREGULATED MIRNAS IN MELANOMA}

Expression pattern of miRNAs in melanoma cell lines and clinical specimens has been assessed by both high throughput and candidate gene approaches. An example of the former types of studies is the study conducted by Zhang et al. (10). They reported DNA copy number changes in miRNA coding genes in the majority of the assessed melanoma samples. Notably, miRNA copy alterations have been correlated with miRNA expression. Moreover, they reported copy number alterations in genes contributing in the biogenesis or function of miRNAs in tumor samples (10). Through a microarray-based technique, Aksenenko et al. have identified differential expression of 143 miRNAs between melanoma samples and adjacent skin tissues. Among the dysregulated miRNAs has been the up-regulated miRNA hsa-miR-146a-5p which has been predicted to be associated with Toll-like receptor, NF- $\kappa \mathrm{B}$ and ErB pathways. Moreover, this miRNA has been shown to target one of the most recurrently mutated genes in melanoma i.e., the NRAS gene (11).

miRNA also affect activity of melanoma-related signaling pathways. Figure 1 depicts the functional association between two miRNAs and AKT and NF- $\mathrm{KB}$ signaling pathways.

Expression profiling of miRNAs in melanocytes and melanoma cells originated from primary or metastatic melanoma cells has provided valuable data about the role of miRNAs in each phase of cancer development. A panel of miRNAs including miR-133a, miR-199b, miR-453, miR-520f, miR-521, and miR-551b has been found consistently upregulated in the course of cancer development from melanocytes to primary cancerous cell and from primary to metastatic melanomas. On the other hand, miR-190 had the opposite trend during this course. Furthermore, expressions of miR-126, miR-29c, miR-506, miR-507, and miR-520d* have been found to be increased during the early progression of melanoma and have been decreased in the metastatic phase. Two other miRNAs including miR-489 and miR-527 had the opposite pattern of expression (15). Levati et al. have demonstrated up-regulation of miR-17-5p, miR-18a, miR-20a, and miR-92a while down-regulation of miR-146a, miR-146b and miR-155 in most of assessed melanoma cell lines compared with melanocytes (16).

Other studies have reported dysregulation of several other miRNAs in the melanoma samples. Among up-regulated miRNAs are miR-221 and miR-222 which induce malignant features through decreasing expression of c-KIT receptor and p27Kip. Both miRNAs promote epithelial-mesenchymal transition $(17,18)$. Moreover, expression of miR-210 has been demonstrated to be elevated in several cancer types including melanoma. Its expression has been correlated with metastatic potential of melanoma tumors. Up-regulation of miR-210 in cancer cell lines facilitates evasion from hypoxia-induced cell cycle arrest and partly upturned the hypoxic gene expression profile. This miRNA has been revealed to target a known MYC antagonist namely MNT. Therefore, miR-210 has been shown to modulate the hypoxia response in cancer cells via regulating an important transcriptional suppressor of the MYC-MAX axis (19). In an attempt to detect the miRNAs that are regulated by BRAFV600E mutation via the ERK pathway, Vitiello et al. have conducted RNA sequencing on A375 cell line and a vemurafenib-resistant clone. Their experiments have led to identification of miR-204 and miR-211 as the utmost overexpressed miRNAs by vemurafenib. In spite of belonging to an identical miRNA family, miR-204 and miR-211 have distinguishing characteristics. miR-204 is regulated by STAT3 and its transcript levels are increased in amelanotic melanoma cells, where it functions as a mediator of antimigratory effects of vemurafenib by modulating expression of AP1S2. On the contrary, miR-211, as a direct target of MITF, is over-expressed in melanotic melanoma cells. miR-211 regulates expression of EDEM1 and subsequently weakens the destruction of Tyrosinase. Thus, miR-211 is a facilitator of pro-pigmentation function of vemurafenib (20). Table 1 displays the list of over-expressed miRNAs in melanoma.

Numerous tumor suppressor miRNAs have been downregulated in melanoma samples. For instance, while miR-34a is constantly detected in normal melanocytes, it is not expressed in uveal melanoma cells. Forced over-expression of this miRNA in uveal melanoma cells remarkably diminishes their growth and migratory abilities. Mechanistically, this miRNA inhibits expression of c-Met protein and decreases the levels of phosphorylated Akt and cell cycle-related proteins (83). Besides, miR-34b, miR-34c, and miR-199a* have been shown to down-regulate MET expression, suppressing the invasive growth features in the melanoma cells (84). Furthermore, expressions of the let-7 miRNAs have been shown to be decreased in primary melanomas compared with benign nevus samples. Forced up-regulation of let-7b in melanoma cells has led to significant decrease in the expression of cyclins D1, D3, and $\mathrm{A}$, and CDK4. The functional interaction between let-7b and 


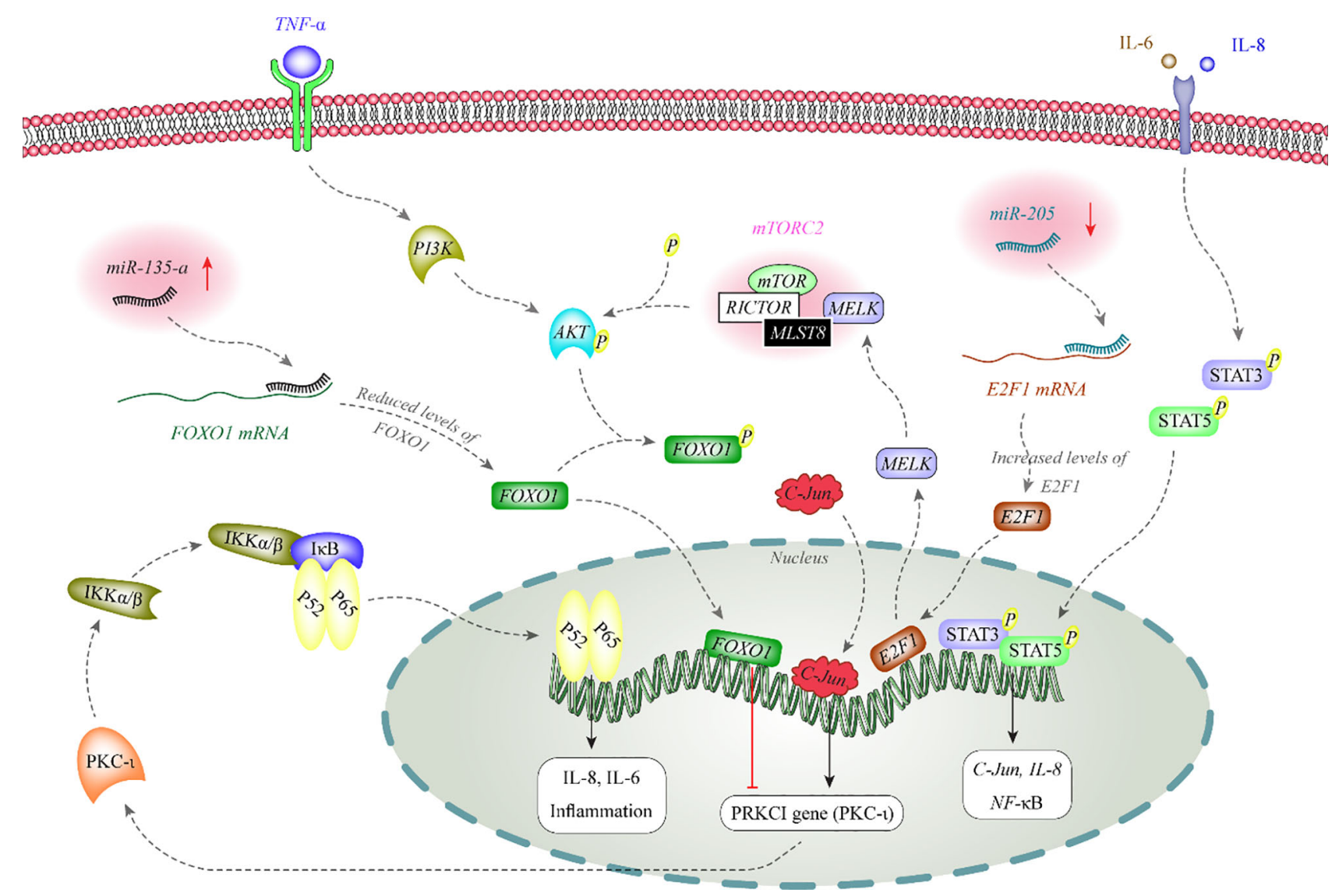

FIGURE 1 | AKT phosphorylates FOXO1 to inhibit its nuclear translocation. FOXO1 has a role in the suppression of expression of PKC-iota in the nucleus. PKC-iota is an inducer of NF-KB which enhances expression of inflammatory genes in the nucleus. Expression of miR-135-a is increased in melanoma. This miRNA binds with the 3' UTR of FOXO1 to decrease its expression $(12,13)$. On the other hand, miR-205 is decreased in melanoma. This miRNA inhibits expression of E2F1 through binding with its 3' UTR. E2F1 increases expression of MELK. MELK activates mTORC2 through binding with MLST8. mTORC2 has a role in phosphorylation and activation of AKT (14).

cyclin D1 has been verified through in vitro experiments (85). The inhibitory effect of let-7a on expression of integrin beta 3 has been verified in another study (86). In addition, functional studies have shown the role of miR-155 in the suppression of proliferation of a number of melanoma cell lines and induction of apoptosis in these cells (16). Table 2 lists the down-regulated miRNAs in melanoma.

\section{DIAGNOSTIC/PROGNOSTIC MIRNAS IN MELANOMA}

Hanniford et al. have introduced a miRNA panel consisting of miR-150-5p, miR-15b-5p, miR-16-5p, and miR-374b-3p whose expression levels could predict the possibility of brain metastasis of melanoma tumors along with clinical stage. Moreover, Kaplan-Meier analysis showed the significance of this miRNA panel in determination of brain-metastasis-free and overall survival of patients with melanoma (273). Stark et al. have assessed expression levels of 17 miRNAs in both melanoma tissues and serum samples of these patients compared with cancer-free individuals. Expression levels of these miRNAs in melanoma samples have been shown to predict stage, recurrence, and survival of patients. Notably, serum expression of a sevenmiRNA panel could distinguish melanoma patients from control subjects with $93 \%$ sensitivity and more than $82 \%$ specificity if at least 4 miRNAs were expressed. Based on the superiority of this miRNA panel above the conventional serological biomarkers for melanoma, it has been suggested as a tool for monitoring disease course in early metastatic melanoma cases to identify relapse after tumor excision or adjuvant therapy (23). Worley et al. have used a high throughput technique to identify the miRNAs whose expression profile could predict the metastatic potential of uveal melanomas. Their approach led to identification of let-7b and miR-199a as the most robust discriminators. Notably, expression profile of six miRNAs could differentiate low and high risk groups with optimal sensitivity and specificity values (274). Table 3 shows the role of miRNAs in the prediction of prognosis of melanoma using Kaplan-Meier or Cox regression analyses. 
TABLE 1 | List of over-expressed miRNAs in melanoma.

\begin{tabular}{|c|c|c|c|c|c|c|c|c|}
\hline microRNA & Samples & Assessed cell lines & $\begin{array}{l}\text { Functional } \\
\text { analysis }\end{array}$ & $\begin{array}{c}\text { Gene } \\
\text { interaction }\end{array}$ & $\begin{array}{l}\text { Signaling } \\
\text { pathway }\end{array}$ & $\begin{array}{l}\text { Association } \\
\text { with clinical } \\
\text { features }\end{array}$ & Function & Reference \\
\hline$m i R-211$ & $\begin{array}{l}\text { SCID mice (SKMEL28 or } \\
\text { SK-P8-2 or 501-Mel and } \\
501-M e l-P 5-5 \text { cell lines were } \\
\text { injected to mice) }\end{array}$ & $\begin{array}{l}\text { SKMEL28, } \\
\text { vemurafenib-resistant } \\
\text { SKMEL28 and 501-Mel } \\
\text { cell lines }\end{array}$ & Yes & - & $\begin{array}{l}\text { PI3K } \\
\text { signaling } \\
\text { pathway }\end{array}$ & - & $\begin{array}{l}\text { Has oncogenic role. Its } \\
\text { deletion attenuates } \\
\text { proliferation, invasion and } \\
\text { tumorigenicity and inhibits } \\
\text { PI3K signaling. Also } \\
\text { induces metabolic } \\
\text { vulnerability of melanoma } \\
\text { cells and sensitizes } \\
\text { vemurafenib resistant cells } \\
\text { to vemurafenib }\end{array}$ & (21) \\
\hline $\begin{array}{l}\operatorname{miR}-211- \\
5 p\end{array}$ & $\begin{array}{l}\mathrm{NOD} / \mathrm{SCID} / \mathrm{L} 2 \mathrm{gR}^{-/-} \text {(NSG) } \\
\text { mice (A375 cell line was } \\
\text { injected to mice) }\end{array}$ & $\begin{array}{l}\text { A375, SK-Mel-103, } \\
\text { SK-Mel-28, SK-Mel- } \\
147\end{array}$ & Yes & $\begin{array}{l}\text { NUAK1, } \\
\text { SLUG }\end{array}$ & - & - & $\begin{array}{l}\text { Promotes proliferation and } \\
\text { induces resistance to } \\
\text { vemurafenib and MEK } \\
\text { inhibitor trametinib in } \\
\text { melanoma cells }\end{array}$ & (22) \\
\hline $\operatorname{miR}-16$ & $\begin{array}{l}86 \text { melanoma tissues, } \\
\text { serum samples from } 130 \\
\text { healthy controls and } 255 \\
\text { melanoma patients }\end{array}$ & - & No & - & - & Disease stage & $\begin{array}{l}\text { A possible diagnostic } \\
\text { biomarker }\end{array}$ & (23) \\
\hline $\begin{array}{l}\text { miR-204- } \\
5 p\end{array}$ & $\begin{array}{l}\mathrm{NOD} / \mathrm{SCID} / \mathrm{L} 2 \mathrm{gR}^{-/ /} \text {(NSG) } \\
\text { mice (A375 cell line was } \\
\text { injected to mice) }\end{array}$ & $\begin{array}{l}\text { A375, SK-Mel-103, } \\
\text { SK-Mel-28, SK-Mel- } \\
147\end{array}$ & Yes & $\begin{array}{l}\text { EFNB2, } \\
\text { NUAK1, } \\
\text { SLUG }\end{array}$ & - & - & $\begin{array}{l}\text { Promotes proliferation and } \\
\text { induces resistance to } \\
\text { vemurafenib and MEK } \\
\text { inhibitor trametinib in } \\
\text { melanoma cells }\end{array}$ & (22) \\
\hline miR-378 & $\begin{array}{l}36 \text { melanoma tissues and } \\
\text { paired ANTs, } 14 \text { Nude } \\
\text { athymic BalB/C mice (A875 } \\
\text { cell line was injected to } \\
\text { mice) }\end{array}$ & A875, A375 & Yes & FOXN3 & $\begin{array}{l}\text { Wnt/ } \beta- \\
\text { catenin } \\
\text { signaling } \\
\text { pathway }\end{array}$ & $\begin{array}{l}\text { lymph node } \\
\text { metastasis }\end{array}$ & $\begin{array}{l}\text { Induces migration and } \\
\text { invasion and activates } \\
\text { EMT process in melanoma } \\
\text { cells through } \\
\text { downregulation of FOXN3 } \\
\text { and activation of Wnt/ } \beta \text { - } \\
\text { catenin pathway }\end{array}$ & (24) \\
\hline miR-1908 & $\begin{array}{l}71 \text { paraffin-embedded } \\
\text { melanoma skin lesions, } \\
\text { NOD scid, NOD scid }\end{array}$ & $\begin{array}{l}\text { MeWo-LM2, A375, SK- } \\
\text { Mel-2, WM-266-4, HT- } \\
\text { 144, A2058, HUVECs }\end{array}$ & Yes & $\begin{array}{l}\text { ApoE, } \\
\text { DNAJA4 }\end{array}$ & $\begin{array}{l}\text { ApoE } \\
\text { signaling }\end{array}$ & $\begin{array}{l}\text { shorter } \\
\text { metastasis-free } \\
\text { survival }\end{array}$ & $\begin{array}{l}\text { Augments invasion, } \\
\text { metastasis, metastatic } \\
\text { endothelial recruitment }\end{array}$ & (26) \\
\hline $\begin{array}{l}\text { miR-199a- } \\
3 p\end{array}$ & $\begin{array}{l}\text { gamma, athymic nu/nu, and } \\
\text { C57Bl6 mice (MeWo-LM2 } \\
\text { cell line was injected to }\end{array}$ & & Yes & $\begin{array}{l}\text { ApoE, } \\
\text { DNAJA4 }\end{array}$ & $\begin{array}{l}\text { ApoE } \\
\text { signaling }\end{array}$ & $\begin{array}{l}\text { shorter } \\
\text { metastasis-free } \\
\text { survival }\end{array}$ & $\begin{array}{l}\text { (MER) and angiogenesis in } \\
\text { melanoma cells through } \\
\text { targeting ApoE and }\end{array}$ & (26) \\
\hline $\begin{array}{l}\text { miR-199a- } \\
5 p\end{array}$ & mice) & & Yes & $\begin{array}{l}\text { ApoE, } \\
\text { DNAJA4 }\end{array}$ & $\begin{array}{l}\text { ApoE } \\
\text { signaling }\end{array}$ & $\begin{array}{l}\text { shorter } \\
\text { metastasis-free } \\
\text { survival }\end{array}$ & DNAJA4 & (26) \\
\hline miR-106b & $\begin{array}{l}97 \text { primary cutaneous } \\
\text { melanoma tissue samples, } \\
17 \text { melanoma metastases, } \\
15 \text { dysplastic nevi }\end{array}$ & - & No & - & - & $\begin{array}{l}\text { Poor } \\
\text { prognosis, } \\
\text { Breslow } \\
\text { thickness, } \\
\text { tumor } \\
\text { ulceration, } \\
\text { advanced } \\
\text { clinical stage }\end{array}$ & $\begin{array}{l}\text { May implicate in } \\
\text { progression of cutaneous } \\
\text { melanoma and can be a } \\
\text { potential prognostic } \\
\text { biomarker }\end{array}$ & (27) \\
\hline miR-106a & - & A375, A2058, HEMn, & Yes & $\mathrm{C} \times 43$ & - & - & $\begin{array}{l}\text { Enhances melanoma cells } \\
\text { proliferation via } \\
\text { suppression of } \mathrm{C} \times 43\end{array}$ & (28) \\
\hline
\end{tabular}


TABLE 1 | Continued

\begin{tabular}{|c|c|c|c|c|c|c|c|c|}
\hline microRNA & Samples & Assessed cell lines & $\begin{array}{l}\text { Functional } \\
\text { analysis }\end{array}$ & $\begin{array}{c}\text { Gene } \\
\text { interaction }\end{array}$ & $\begin{array}{l}\text { Signaling } \\
\text { pathway }\end{array}$ & $\begin{array}{l}\text { Association } \\
\text { with clinical } \\
\text { features }\end{array}$ & Function & Reference \\
\hline miR-146a & $\begin{array}{l}\text { Mice (A375 cell line was } \\
\text { injected to mice) }\end{array}$ & $\begin{array}{l}\text { A375, MA-1, MC-1, } \\
\text { MA-2, MC-2, WK-Mel }\end{array}$ & Yes & $\begin{array}{l}\text { LFNG, } \\
\text { NUMB, } \\
\text { ITGAV, } \\
\text { ROCK1 }\end{array}$ & $\begin{array}{l}\text { NOTCH/ } \\
\text { PTEN/Akt } \\
\text { pathway }\end{array}$ & - & $\begin{array}{l}\text { Has dual function. It } \\
\text { enhances melanoma cell } \\
\text { growth but inhibits } \\
\text { metastasis formation (and } \\
\text { is poorly expressed in } \\
\text { circulating tumor cells) }\end{array}$ & (30) \\
\hline miR-146a & $\begin{array}{l}55 \text { melanoma tissues and } \\
\text { paired ANTs }\end{array}$ & $\begin{array}{l}\text { A375, WM115, M14, } \\
\text { G361, HACAT }\end{array}$ & Yes & SMAD4 & - & $\begin{array}{l}\text { TNM stage, } \\
\text { lymph node } \\
\text { metastasis }\end{array}$ & $\begin{array}{l}\text { Promotes migration and } \\
\text { invasion of melanoma cells } \\
\text { through targeting SMAD4 }\end{array}$ & (32) \\
\hline miR-10b & $\begin{array}{l}\text { FFPE tissue specimens of } \\
40 \text { primary melanomas that } \\
\text { are metastasis-free, } 39 \\
\text { primary melanomas with } \\
\text { metastasis, } 32 \text { metastases }\end{array}$ & - & No & - & - & $\begin{array}{l}\text { Tumor } \\
\text { metastasis }\end{array}$ & $\begin{array}{l}\text { Is a potential prognostic } \\
\text { biomarker in detection of } \\
\text { thicker melanomas that } \\
\text { have enhanced risk of } \\
\text { metastasis }\end{array}$ & (33) \\
\hline$m i R-10 b$ & - & $\begin{array}{l}\text { Mel 505, PMWK, sk- } \\
\text { mel-28, sk-mel-24, } \\
\text { VMM39, MEL 224, } \\
\text { YUHEF, YUROB, }\end{array}$ & Yes & - & - & - & $\begin{array}{l}\text { Its expression positively } \\
\text { correlates with B- } \\
\text { RafV600E mutation and } \\
\text { increases anchorage- } \\
\text { independent growth of B- } \\
\text { Raf wild-type melanoma } \\
\text { cells }\end{array}$ & (34) \\
\hline $\operatorname{miR}-21$ & $\begin{array}{l}67 \text { malignant melanoma } \\
\text { tissue and } 67 \text { normal control } \\
\text { skin samples }\end{array}$ & - & No & PDCD4 & - & $\begin{array}{l}\text { tumor size, } \\
\text { higher Clark } \\
\text { classification } \\
\text { level, lymph } \\
\text { node } \\
\text { metastases }\end{array}$ & $\begin{array}{l}\text { Can be a possible } \\
\text { biomarker or therapeutic } \\
\text { target in melanoma }\end{array}$ & (36) \\
\hline miR-21 & $\begin{array}{l}86 \text { primary cutaneous } \\
\text { melanomas tissues, } 10 \\
\text { melanoma metastases, } 10 \\
\text { dysplastic nevi samples }\end{array}$ & HTB-67, A375 & Yes & - & - & $\begin{array}{l}\text { Overall survival, } \\
\text { Breslow } \\
\text { thickness, } \\
\text { advanced } \\
\text { clinical stage, }\end{array}$ & $\begin{array}{l}\text { Its silencing suppresses } \\
\text { growth and increases } \\
\text { apoptosis, } \\
\text { chemosensitivity and } \\
\text { radiosensitivity of } \\
\text { melanoma cells }\end{array}$ & (37) \\
\hline miR-21 & $\begin{array}{l}12 \text { FFPE primary melanoma } \\
\text { tissues and } 12 \text { melanocytic } \\
\text { nevi }\end{array}$ & $\begin{array}{l}\text { WM9, WM35b, } \\
\text { WM451, WM793, } \\
\text { WM951, } \\
\text { WM1205, SKMel23, } \\
\text { SKMel113, MV3, } \\
\text { MEWO }\end{array}$ & Yes & Cdc25a & - & $\begin{array}{l}\text { Recurrence- } \\
\text { free survival, } \\
\text { overall survival }\end{array}$ & $\begin{array}{l}\text { Its downregulation } \\
\text { promotes apoptosis. }\end{array}$ & (38) \\
\hline$m i R-21$ & $\begin{array}{l}\text { female 01B74 Athymic NCr- } \\
\text { nu/nu mice (A375 cell line } \\
\text { was injected to mice) }\end{array}$ & $\begin{array}{l}\text { WM1552c, WM793b, } \\
\text { MEL 39, A375 }\end{array}$ & Yes & TIMP3 & - & - & $\begin{array}{l}\text { Increases invasive ability of } \\
\text { melanoma cells through } \\
\text { targeting TIMP3 }\end{array}$ & (39) \\
\hline
\end{tabular}


TABLE 1 | Continued

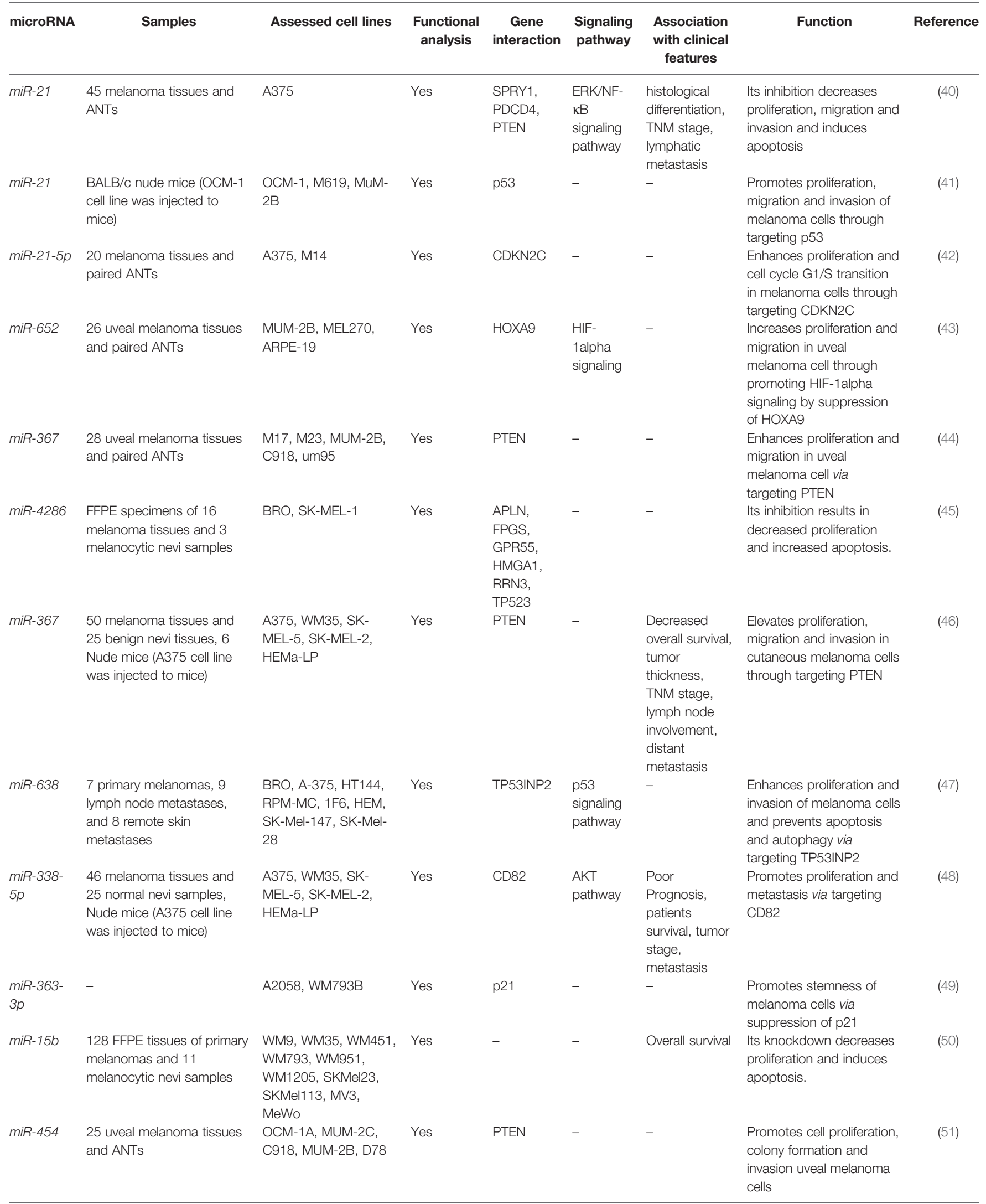


TABLE 1 | Continued

\begin{tabular}{|c|c|c|c|c|c|c|c|c|}
\hline microRNA & Samples & Assessed cell lines & $\begin{array}{l}\text { Functional } \\
\text { analysis }\end{array}$ & $\begin{array}{c}\text { Gene } \\
\text { interaction }\end{array}$ & $\begin{array}{l}\text { Signaling } \\
\text { pathway }\end{array}$ & $\begin{array}{c}\text { Association } \\
\text { with clinical } \\
\text { features }\end{array}$ & Function & Reference \\
\hline $\operatorname{miR}-214$ & $\begin{array}{l}57 \text { primary melanoma } \\
\text { tissues, } 13 \text { in situ } \\
\text { melanomas and } 18 \\
\text { cutaneous metastases, } \\
\text { female CD1 nude mice } \\
\text { (A375 or } 106 \text { WK-Mel, GR4- } \\
\text { Mel, } 1300-M e l, \text { SK-Mel-173 } \\
\text { and SK-Mel-197 cell lines } \\
\text { were injected to mice) }\end{array}$ & $\begin{array}{l}\text { 293T, MDA-MB-231, } \\
\text { 4T1, A375, 1300-Mel, } \\
\text { GR4-Mel, WK-Mel, } \\
\text { Dett-Mel, SK-MEL-103, } \\
\text { SK-MEL-173, SK-MEL- } \\
\text { 187, SK-MEL-197, } \\
\text { HEMa-LP }\end{array}$ & Yes & TFAP2C & - & - & $\begin{array}{l}\text { Enhances cell movement } \\
\text { and metastasis via } \\
\text { suppression of TFAP2C }\end{array}$ & (52) \\
\hline $\begin{array}{l}\text { miR-122- } \\
5 p\end{array}$ & $\begin{array}{l}\text { Human melanoma tissues } \\
\text { and pigmented nevus } \\
\text { tissues }\end{array}$ & $\begin{array}{l}\text { 293T, SK-MEL-110, } \\
\text { A375 }\end{array}$ & Yes & NOP14 & - & - & $\begin{array}{l}\text { Its inhibition represses } \\
\text { proliferation and induces } \\
\text { cell cycle arrest at G1 } \\
\text { phases through regulation } \\
\text { of NOP14 }\end{array}$ & (53) \\
\hline$m i R-221$ & $\begin{array}{l}\text { Serum samples from } 72 \\
\text { cutaneous malignant } \\
\text { melanoma and } 54 \text { healthy } \\
\text { controls }\end{array}$ & - & No & - & - & $\begin{array}{l}\text { Patient survival, } \\
\text { tumor } \\
\text { thickness, } \\
\text { differentiation, } \\
\text { T classification, } \\
N \text { classification, } \\
\text { metastasis, } \\
\text { advanced } \\
\text { clinical stage }\end{array}$ & $\begin{array}{l}\text { Can be a potential } \\
\text { prognostic biomarker in } \\
\text { cutaneous melanoma }\end{array}$ & (55) \\
\hline $\operatorname{miR}-135 a$ & $\begin{array}{l}20 \text { melanoma tissues and } \\
\text { paired ANTs }\end{array}$ & HEM, sk-mel-1, A375 & Yes & FOXO1 & $\begin{array}{l}\text { AKT } \\
\text { signaling } \\
\text { pathway }\end{array}$ & - & $\begin{array}{l}\text { Promotes melanoma cells } \\
\text { proliferation, tumorigenicity } \\
\text { and cell cycle progression } \\
\text { via targeting FOXO1 }\end{array}$ & (12) \\
\hline miR-135b & $\begin{array}{l}20 \text { melanoma tissues and } \\
\text { paired ANTs }\end{array}$ & A-375 & Yes & LATS2 & - & - & $\begin{array}{l}\text { Its inhibition decreases } \\
\text { proliferation and migration } \\
\text { and induces apoptosis in } \\
\text { melanoma cells }\end{array}$ & (57) \\
\hline miR-25 & - & $\begin{array}{l}\text { A875, MV3, M14, } \\
\text { uacc-257, HEM-a }\end{array}$ & Yes & RBM47 & $\begin{array}{l}\text { PI3K/Akt/ } \\
\text { mTOR } \\
\text { signaling } \\
\text { pathway }\end{array}$ & - & $\begin{array}{l}\text { Promotes proliferation and } \\
\text { migration of melanoma } \\
\text { cells through targeting } \\
\text { RBM47 }\end{array}$ & (58) \\
\hline miR-25 & $\begin{array}{l}30 \text { primary melanoma } \\
\text { tissues and related non- } \\
\text { cancerous skin samples }\end{array}$ & $\begin{array}{l}\text { HEM, MV3, SK-HEP-1, } \\
\text { A375 }\end{array}$ & Yes & DKK3 & $\begin{array}{l}\text { WNT/B- } \\
\text { Catenin } \\
\text { signaling } \\
\text { Pathway }\end{array}$ & - & $\begin{array}{l}\text { Enhances proliferation and } \\
\text { invasion in melanoma cells } \\
\text { via targeting DKK3 }\end{array}$ & (59) \\
\hline miR-125a & 22 melanoma tissue & $\begin{array}{l}\text { SK-MEL-239, A375, } \\
\text { 451Lu }\end{array}$ & Yes & $\begin{array}{l}\text { BAK1, } \\
\text { MLK3 }\end{array}$ & - & - & $\begin{array}{l}\text { Promotes BRAF inhibitors } \\
\text { resistance through } \\
\text { inhibition of intrinsic } \\
\text { apoptotic pathway by } \\
\text { targeting BAK1 and MLK3 }\end{array}$ & (60) \\
\hline
\end{tabular}


TABLE 1 | Continued

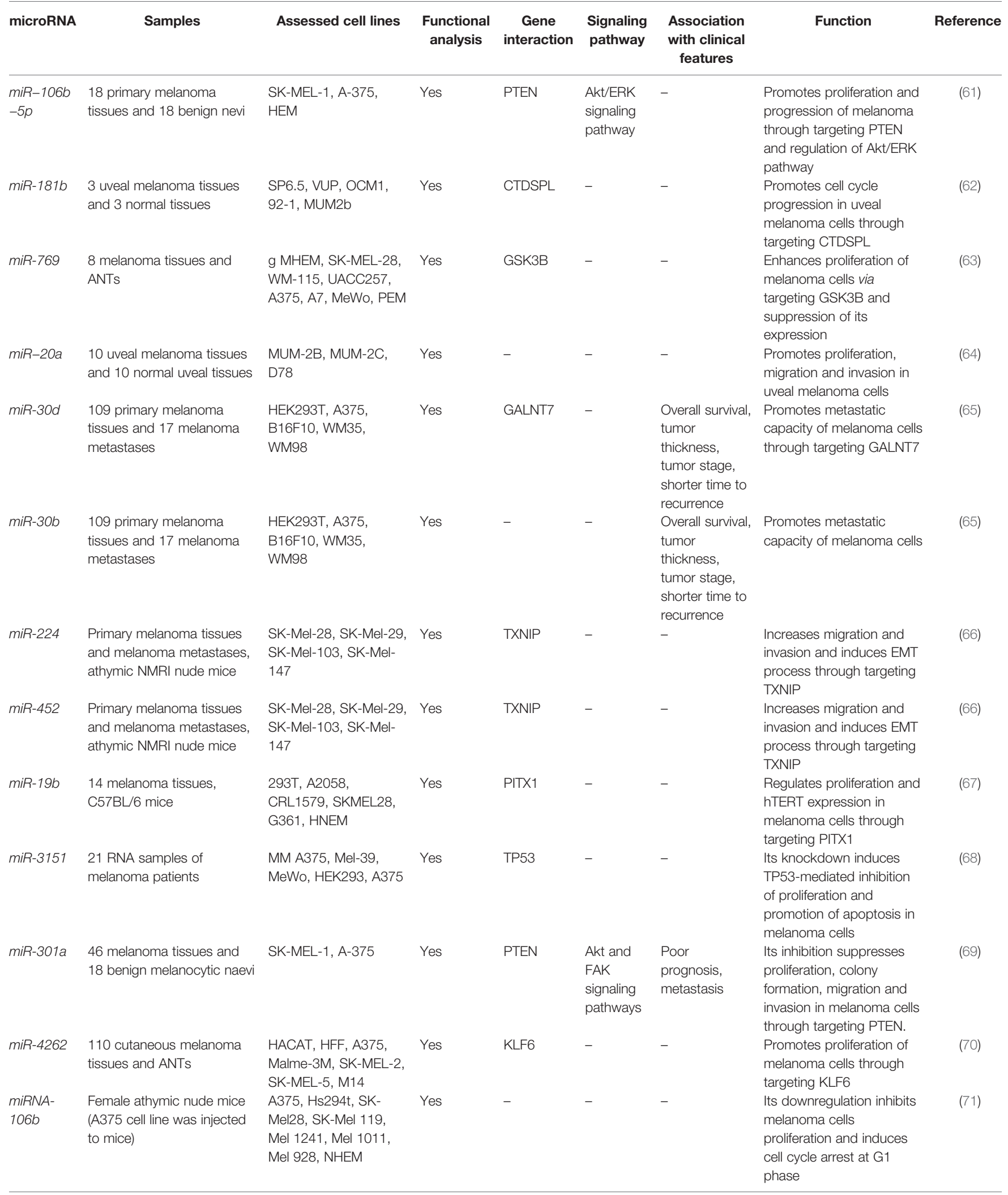


TABLE 1 | Continued

\begin{tabular}{|c|c|c|c|c|c|c|c|c|}
\hline microRNA & Samples & Assessed cell lines & $\begin{array}{l}\text { Functional } \\
\text { analysis }\end{array}$ & $\begin{array}{c}\text { Gene } \\
\text { interaction }\end{array}$ & $\begin{array}{l}\text { Signaling } \\
\text { pathway }\end{array}$ & $\begin{array}{l}\text { Association } \\
\text { with clinical } \\
\text { features }\end{array}$ & Function & Reference \\
\hline miR-519d & $\begin{array}{l}21 \text { primary melanoma } \\
\text { tissues, } 19 \text { normal skin and } \\
21 \text { metastatic melanoma } \\
\text { samples, C.B-17/lcr-scid } \\
\text { mice (A2058 cell line was } \\
\text { injected to mice) }\end{array}$ & $\begin{array}{l}\text { A2058, SK-Mel-28, } \\
\text { A375, SK-Mel-90, } \\
\text { MeWo }\end{array}$ & Yes & EphA4 & $\begin{array}{l}\text { ERK1/2 } \\
\text { signaling } \\
\text { pathway }\end{array}$ & - & $\begin{array}{l}\text { Promotes proliferation, } \\
\text { migration and invasion of } \\
\text { melanoma cells via } \\
\text { downregulation of EphA4 }\end{array}$ & $(72)$ \\
\hline $\operatorname{miR}-370$ & $\begin{array}{l}41 \text { melanoma tissues and } \\
\text { ANTs, BALB/c nude mice } \\
\text { (A375 cell line was injected } \\
\text { to mice) }\end{array}$ & $\begin{array}{l}\text { SK-MEL-1, A375, } \\
\text { HEMn-LP }\end{array}$ & Yes & PDHB & - & TNM stage & $\begin{array}{l}\text { Promotes proliferation, } \\
\text { invasion and glycolysis in } \\
\text { melanoma cells and } \\
\text { induces apoptosis through } \\
\text { targeting PDHB }\end{array}$ & (73) \\
\hline $\operatorname{miR}-373$ & $\begin{array}{l}16 \text { melanoma tissues and } \\
\text { normal skin samples }\end{array}$ & $\begin{array}{l}\text { A375, WM115, WM75, } \\
\text { mela }\end{array}$ & Yes & SIK1 & - & - & $\begin{array}{l}\text { Promotes migration of } \\
\text { melanoma cells through } \\
\text { targeting SIK1 }\end{array}$ & $(74)$ \\
\hline miR-92a & $\begin{array}{l}75 \text { melanoma tissues and } \\
\text { paired ANTs }\end{array}$ & $\begin{array}{l}\text { A375.S2, A7, MeWo, } \\
\text { RPMI-7951, SK-MEL- } \\
\text { 5, SK-MEL-24, } \\
\text { SKMEL-28, PEM }\end{array}$ & Yes & - & - & $\begin{array}{l}\text { Overall survival, } \\
\text { tumor stage, } \\
\text { lymph node } \\
\text { metastasis, } \\
\text { distant } \\
\text { metastasis }\end{array}$ & $\begin{array}{l}\text { Its knockdown suppresses } \\
\text { proliferation and migration } \\
\text { of melanoma cells }\end{array}$ & $(75)$ \\
\hline $\operatorname{miR}-517$ & $\begin{array}{l}62 \text { melanoma tissues and } \\
40 \text { normal skin tissues }\end{array}$ & $\begin{array}{l}\text { HACAT, A375, G-361, } \\
\text { OCM-1 }\end{array}$ & Yes & CDKN1C & $\begin{array}{l}\text { JNK } \\
\text { signaling } \\
\text { pathway }\end{array}$ & - & $\begin{array}{l}\text { Its silencing induces } \\
\text { oxidative stress injury in } \\
\text { melanoma cells through } \\
\text { upregulation of CDKN1C } \\
\text { and inactivation of JNK } \\
\text { signaling pathway }\end{array}$ & $(76)$ \\
\hline miR-27a & $\begin{array}{l}43 \text { paraffin-embedded } \\
\text { melanoma tissues and } 22 \\
\text { pigmented nevus samples, } \\
\text { female BALB/c nude mice } \\
\text { (A375 cell line was injected } \\
\text { to mice) }\end{array}$ & Mel-RM, A375 & Yes & SYK & $\begin{array}{l}\text { mTOR } \\
\text { signaling } \\
\text { pathway }\end{array}$ & $\begin{array}{l}\text { TNM staging, } \\
\text { lymph node } \\
\text { metastasis }\end{array}$ & $\begin{array}{l}\text { Its silencing promotes } \\
\text { autophagy and apoptosis } \\
\text { in melanoma cells through } \\
\text { SYK-mediated modulation } \\
\text { of mTOR signaling } \\
\text { pathway }\end{array}$ & $(77)$ \\
\hline miR-186 & $\begin{array}{l}8 \text { melanoma tissues and } \\
\text { ANTs }\end{array}$ & $\begin{array}{l}\text { A375-S2, SKMEL-28, } \\
\text { SKMEL-5, MeWO, } \\
\text { RPMI-7951, NHEM }\end{array}$ & Yes & CYLD & - & - & $\begin{array}{l}\text { Enhances proliferation and } \\
\text { anchorage-independent } \\
\text { growth of melanoma cells } \\
\text { via downregulation of } \\
\text { CYLD }\end{array}$ & (78) \\
\hline $\operatorname{miR}-1246$ & $\begin{array}{l}\text { Tissues from } 43 \text { melanoma } \\
\text { patients }\end{array}$ & HEM, A375, A2058 & Yes & FOXA2 & - & - & $\begin{array}{l}\text { promoted cell viability and } \\
\text { metastasis in melanoma } \\
\text { cells via targeting FOXA2 }\end{array}$ & (79) \\
\hline $\operatorname{miR}-150$ & $\begin{array}{l}20 \text { melanoma tissues and } \\
\text { paired ANTs }\end{array}$ & $\begin{array}{l}\text { M14, A357, WM115, } \\
\text { NHEM }\end{array}$ & Yes & PDCD4 & - & - & $\begin{array}{l}\text { Its silencing inhibits cell } \\
\text { proliferation, migration and } \\
\text { invasion and induces } \\
\text { apoptosis in melanoma } \\
\text { cells. }\end{array}$ & (80) \\
\hline miR-520f & $\begin{array}{l}10 \text { melanoma and paired } \\
\text { ANTs }\end{array}$ & $\begin{array}{l}\text { UACC257, WM-115, } \\
\text { A7, MeWo, A375, } \\
\text { NHEM, WM-115, PEM }\end{array}$ & Yes & $\mathrm{ITCH}$ & - & - & $\begin{array}{l}\text { Promotes proliferation, } \\
\text { colony construction and } \\
\text { anchorage-independent } \\
\text { growth in melanoma cells } \\
\text { via targeting ITCH }\end{array}$ & (81) \\
\hline miR-633 & $\begin{array}{l}11 \text { melanoma tissues and } \\
10 \text { ANTs }\end{array}$ & $\begin{array}{l}\text { A375, A2058, B16, } \\
\text { MEL-RM and M21 }\end{array}$ & Yes & KAl1 & - & - & $\begin{array}{l}\text { Raises migratory ability } \\
\text { and proliferation of } \\
\text { melanoma cells via } \\
\text { targeting KAl1 and } \\
\text { reducing KAl1 expression }\end{array}$ & (82) \\
\hline
\end{tabular}

Receiver operating characteristic (ROC) curves have been used to assess the diagnostic or prognostic values of miRNAs in melanoma. Based on the area under curve (AUC) values, several miRNAs can be suggested as appropriate biomarkers for this kind of cancer. In the field of miRNA application in melanoma diagnosis, these curves depict the diagnostic capability of expression level of a miRNA as a binary classifier system for detection of melanoma cases as its discrimination threshold is 
TABLE 2 | List of under-expressed miRNAs in melanoma.

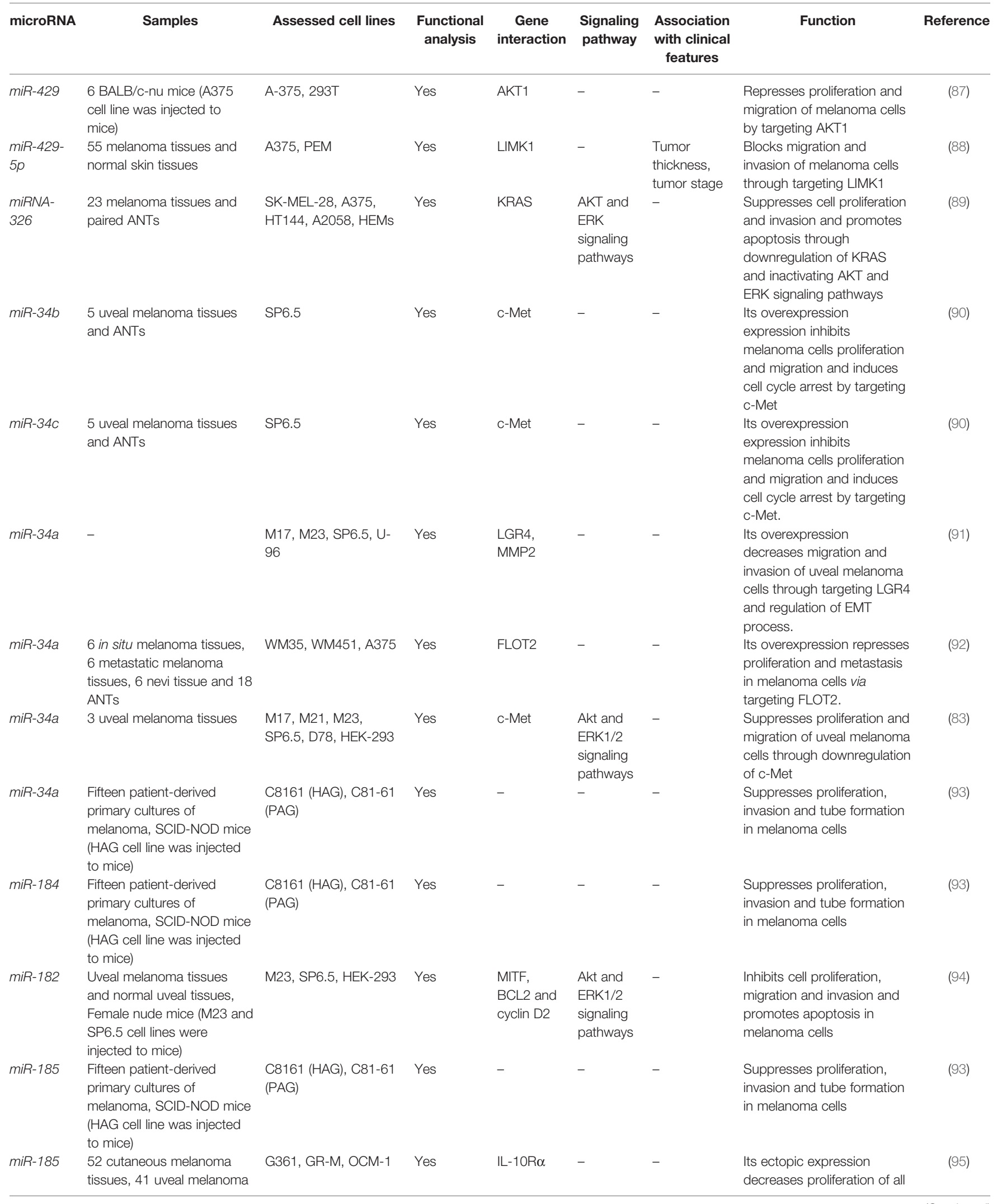


TABLE 2 | Continued

\begin{tabular}{|c|c|c|c|c|c|c|c|c|}
\hline microRNA & Samples & Assessed cell lines & $\begin{array}{l}\text { Functional } \\
\text { analysis }\end{array}$ & $\begin{array}{c}\text { Gene } \\
\text { interaction }\end{array}$ & $\begin{array}{l}\text { Signaling } \\
\text { pathway }\end{array}$ & $\begin{array}{l}\text { Association } \\
\text { with clinical } \\
\text { features }\end{array}$ & Function & Reference \\
\hline & $\begin{array}{l}\text { tissues and } 35 \text { normal skin } \\
\text { specimens }\end{array}$ & & & & & & $\begin{array}{l}\text { melanoma cell lines through } \\
\text { targeting IL-10R } \alpha\end{array}$ & \\
\hline miR-204 & $\begin{array}{l}\text { Fifteen patient-derived } \\
\text { primary cultures of } \\
\text { melanoma, SCID-NOD mice } \\
\text { (HAG cell line was injected } \\
\text { to mice) }\end{array}$ & $\begin{array}{l}\text { C8161 (HAG), C81-61 } \\
\text { (PAG) }\end{array}$ & Yes & - & - & - & $\begin{array}{l}\text { Suppresses proliferation, } \\
\text { invasion and tube formation } \\
\text { in melanoma cells }\end{array}$ & (93) \\
\hline miR-365 & $\begin{array}{l}\text { Skin Cutaneous Melanoma } \\
\text { (SKCM) dataset for } 470 \\
\text { melanoma samples was } \\
\text { downloaded from TCGA }\end{array}$ & $\begin{array}{l}\text { NHEM, A375, A2058, } \\
\text { SK-MEL-2, SK-MEL-28 }\end{array}$ & Yes & $\begin{array}{l}\text { BCL2, } \\
\text { CCND1 }\end{array}$ & - & - & $\begin{array}{l}\text { Inhibits cell proliferation, } \\
\text { migration and invasion and } \\
\text { promotes apoptosis in } \\
\text { melanoma cells. }\end{array}$ & (96) \\
\hline miR-365 & $\begin{array}{l}40 \text { melanoma tissues and } \\
\text { paired ANTs, female BALB/ } \\
\text { c nude mice (A375 cell line } \\
\text { was injected to mice) }\end{array}$ & $\begin{array}{l}\text { A375, G361, LIBR, } \\
\text { HME1 }\end{array}$ & Yes & NRP1 & - & $\begin{array}{l}\text { lymph node } \\
\text { metastasis, } \\
\text { clinical stage, } \\
\text { overall } \\
\text { survival, } \\
\text { relapse-free } \\
\text { survival }\end{array}$ & $\begin{array}{l}\text { Inhibits melanoma growth } \\
\text { and metastasis by targeting } \\
\text { NRP1 }\end{array}$ & (97) \\
\hline $\begin{array}{l}\text { miR-485- } \\
5 p\end{array}$ & $\begin{array}{l}20 \text { human primary } \\
\text { melanoma tissues and } \\
\text { paired ANTs }\end{array}$ & $\begin{array}{l}\text { A375, SK-HEP-1, SK- } \\
\text { MEL-1, MV3, HPM }\end{array}$ & Yes & FZD7 & $\begin{array}{l}\text { wnt } \\
\text { signaling } \\
\text { pathway }\end{array}$ & - & $\begin{array}{l}\text { Suppresses proliferation and } \\
\text { invasion of melanoma cells } \\
\text { through targeting FZD7 and } \\
\text { consequently inhibition of } \\
\text { wnt signaling }\end{array}$ & (98) \\
\hline miR-612 & $\begin{array}{l}89 \text { melanoma tissues and } \\
\text { paired ANTs, nude mice } \\
\text { (A375 cell line was injected } \\
\text { to mice) }\end{array}$ & $\begin{array}{l}\text { SK-MEL-28, SK-MEL- } \\
\text { 3, A375, } \\
\text { HT-144, Hs294T, } \\
\text { HEM, HEK293T }\end{array}$ & Yes & Espin & - & $\begin{array}{l}\text { melanoma } \\
\text { thickness, } \\
\text { lymph node } \\
\text { metastasis, } \\
\text { poor survival }\end{array}$ & $\begin{array}{l}\text { Its overexpression inhibits } \\
\text { melanoma growth, migration } \\
\text { and invasion through } \\
\text { downregulation of Espin also } \\
\text { sensitizes melanoma cells to } \\
\text { doxorubicin }\end{array}$ & (99) \\
\hline $\operatorname{miR}-7-5 p$ & $\begin{array}{l}20 \text { male NOD.CB17- } \\
\text { Prkdcscid II2rgtm1Wj/SzJ } \\
\text { (NSG) mice (1205Lu cell line } \\
\text { was injected to mice) }\end{array}$ & $\begin{array}{l}\text { WM266-4, SK-MEL-2, } \\
\text { A2058, 1205Lu }\end{array}$ & Yes & RelA & $\begin{array}{l}\text { NF-kB } \\
\text { signaling } \\
\text { pathway }\end{array}$ & - & $\begin{array}{l}\text { Inhibits cell proliferation, } \\
\text { migration and invasion in } \\
\text { melanoma via inhibiting RelA } \\
\text { and reducing activity of NF- } \\
\text { КB signaling }\end{array}$ & $(100)$ \\
\hline $\begin{array}{l}\text { miR-153- } \\
3 p\end{array}$ & $\begin{array}{l}20 \text { melanoma tissues and } \\
\text { matched ANTs }\end{array}$ & $\begin{array}{l}\text { A375, SK-MEL-28, } \\
\text { D78 }\end{array}$ & Yes & SNAl1 & - & - & $\begin{array}{l}\text { Its overexpression represses } \\
\text { proliferation and invasion } \\
\text { and induces apoptosis by } \\
\text { downregulating SNAl1 }\end{array}$ & (103) \\
\hline $\operatorname{miR}-625$ & $\begin{array}{l}30 \text { melanoma tissues and } \\
\text { paired ANTs, SPF grade } \\
\text { male BALB/c nude mice } \\
\text { (A375 cell line was injected } \\
\text { to mice) }\end{array}$ & A375, M14 & Yes & sox2 & - & - & $\begin{array}{l}\text { Inhibits proliferation, } \\
\text { migration and invasion of } \\
\text { melanoma cells by targeting } \\
\text { SOX2 }\end{array}$ & (104) \\
\hline miR-23a & $\begin{array}{l}30 \text { specific-pathogen-free } \\
\text { (SPF) closed colony male } \\
\text { ICR mice (B16 cell line was } \\
\text { injected to mice) }\end{array}$ & B16 & Yes & SDCBP & $\begin{array}{l}\text { MAPK } \\
\text { ERK } \\
\text { Signaling } \\
\text { Pathway }\end{array}$ & - & $\begin{array}{l}\text { Its overexpression } \\
\text { decreases proliferation, } \\
\text { migration and invasion and } \\
\text { induces cell cycle arrest at } \\
\text { G1 phase and apoptosis in } \\
\text { melanoma cells via } \\
\text { suppression of SDCBP }\end{array}$ & (105) \\
\hline
\end{tabular}


TABLE 2 | Continued

\begin{tabular}{|c|c|c|c|c|c|c|c|c|}
\hline microRNA & Samples & Assessed cell lines & $\begin{array}{l}\text { Functional } \\
\text { analysis }\end{array}$ & $\begin{array}{c}\text { Gene } \\
\text { interaction }\end{array}$ & $\begin{array}{l}\text { Signaling } \\
\text { pathway }\end{array}$ & $\begin{array}{c}\text { Association } \\
\text { with clinical } \\
\text { features }\end{array}$ & Function & Reference \\
\hline miR-23a & $\begin{array}{l}\text { Serum samples from } 192 \\
\text { melanoma cases and } 51 \\
\text { matched cancer-free } \\
\text { controls, tissue specimens } \\
\text { from } 66 \text { melanoma cases } \\
\text { and } 22 \text { nevus cases, female } \\
\text { BALB/C-Nu nude mice } \\
\text { (A2058 cell line was injected } \\
\text { to mice) }\end{array}$ & $\begin{array}{l}\text { WM35, WM793, } \\
\text { 451LU, A2058, A375 }\end{array}$ & Yes & ATG12 & $\begin{array}{l}\text { AMPK- } \\
\text { RhoA } \\
\text { pathway }\end{array}$ & $\begin{array}{l}\text { Patient } \\
\text { survival, } \\
\text { tumor } \\
\text { thickness, } \\
\text { ulceration, } \\
\text { AJCC stage }\end{array}$ & $\begin{array}{l}\text { Decreases migration and } \\
\text { invasion in melanoma cells } \\
\text { through targeting ATG12 } \\
\text { and regulation of autophagy }\end{array}$ & (106) \\
\hline$m i R-23 b$ & $\begin{array}{l}114 \text { primary melanoma } \\
\text { tissues and ANTs, Nude } \\
\text { mice (A375 and SK-MEL-28 } \\
\text { cell lines were injected to } \\
\text { mice) }\end{array}$ & $\begin{array}{l}\text { A375, Hs294t, SK- } \\
\text { MEL-5, SK-MEL-28, } \\
\text { B16F10, nHEM }\end{array}$ & Yes & NAMPT & $\begin{array}{l}\text { NF-kB } \\
\text { signaling } \\
\text { pathway }\end{array}$ & $\begin{array}{l}\text { Patient } \\
\text { survival, } \\
\text { Clark level, } \\
\text { sentinel- } \\
\text { lymph-node } \\
\text { positive, } \\
\text { AJCC stage }\end{array}$ & $\begin{array}{l}\text { Suppresses cell proliferation } \\
\text { and angiogenesis and } \\
\text { promotes apoptosis through } \\
\text { targeting NAMPT }\end{array}$ & (107) \\
\hline $\begin{array}{l}\text { miR-23a- } \\
3 p\end{array}$ & $\begin{array}{l}117 \text { mucosal melanoma and } \\
12 \text { mucosal nevi, female } \\
\text { NOD/SCID mice (HMVII cell } \\
\text { line was injected to mice) }\end{array}$ & $\begin{array}{l}\text { GAK, VMRC-MELG, } \\
\text { HMVII, HEK293T }\end{array}$ & Yes & $\mathrm{ADCY} 1$ & $\begin{array}{l}\text { CAMP and } \\
\text { MAPK } \\
\text { signaling } \\
\text { pathways }\end{array}$ & $\begin{array}{l}\text { TNM stage, } \\
\text { poor overall } \\
\text { survival and } \\
\text { disease free } \\
\text { survival }\end{array}$ & $\begin{array}{l}\text { Inhibits proliferation, } \\
\text { migration and invasion of } \\
\text { mucosal melanoma cells } \\
\text { through targeting ADCY1 } \\
\text { and inhibition of CAMP and } \\
\text { MAPK signaling pathways }\end{array}$ & (108) \\
\hline$m i R-15 a$ & $\begin{array}{l}24 \text { C57BL/6 mice (B16-F10 } \\
\text { cell line was injected to } \\
\text { mice) }\end{array}$ & $\begin{array}{l}\text { A375, SK-MEL-28, } \\
\text { WM1552C, B16-F10 }\end{array}$ & Yes & $\begin{array}{l}\text { CDCA4, } \\
\text { AKT3 }\end{array}$ & - & - & $\begin{array}{l}\text { Inhibits cell proliferation, } \\
\text { migration and invasion and } \\
\text { contributes to cell cycle } \\
\text { arrest at G1/G0 phase } \\
\text { through targeting CDCA4 }\end{array}$ & (109) \\
\hline $\operatorname{miR}-15 a$ & $\begin{array}{l}52 \text { cutaneous melanoma } \\
\text { tissues, } 41 \text { uveal melanoma } \\
\text { tissues and } 35 \text { normal skin } \\
\text { specimens }\end{array}$ & G361, GR-M, OCM-1 & Yes & $\mathrm{IL}-10 \mathrm{R} \alpha$ & - & - & $\begin{array}{l}\text { Its ectopic expression } \\
\text { decreases proliferation of all } \\
\text { melanoma cell lines through } \\
\text { targeting IL-10R } \alpha\end{array}$ & (95) \\
\hline miR-708 & $\begin{array}{l}60 \text { C57BL/6J male mice } \\
\text { (B16 cell line was injected to } \\
\text { mice) }\end{array}$ & B16, B16F10, HEK293 & Yes & BAMBI & $\begin{array}{l}\text { Wnt } \\
\text { Signaling } \\
\text { Pathway, } \\
\text { TGF- } \beta \\
\text { Signaling } \\
\text { Pathway }\end{array}$ & - & $\begin{array}{l}\text { Its overexpression } \\
\text { decreases proliferation, } \\
\text { migration and invasion and } \\
\text { induces apoptosis in } \\
\text { melanoma cells through } \\
\text { targeting BAMBI and } \\
\text { activation of TGF- } \beta \text { Pathway } \\
\text { and suppression of Wnt } \\
\text { pathway }\end{array}$ & (112) \\
\hline miR-708 & $\begin{array}{l}40 \text { clean male Kunming } \\
\text { mice (B16 cell line was } \\
\text { injected to mice) }\end{array}$ & $\begin{array}{l}\text { B16, A375, WM239, } \\
\text { WM451 }\end{array}$ & Yes & LEF1 & $\begin{array}{l}\text { Wnt } \\
\text { signaling } \\
\text { pathway }\end{array}$ & - & $\begin{array}{l}\text { Its overexpression } \\
\text { expression inhibits } \\
\text { proliferation, migration and } \\
\text { invasion and induces } \\
\text { apoptosis in melanoma cell } \\
\text { through targeting LEF1 }\end{array}$ & (113) \\
\hline miR-216b & $\begin{array}{l}30 \text { melanoma tissues and } \\
\text { ANTs, NOD-SCID mice } \\
\text { (A375 cell line was injected } \\
\text { to mice) }\end{array}$ & $\begin{array}{l}\text { HEK-293T, A375, } \\
\text { A875, SK-MEL-1, } \\
\text { HaCaT }\end{array}$ & Yes & FOXM1 & $\begin{array}{l}\text { FOXM1 } \\
\text { signaling } \\
\text { pathway }\end{array}$ & - & $\begin{array}{l}\text { Decreases proliferation, } \\
\text { migration and colony } \\
\text { formation ability of } \\
\text { melanoma cells by targeting } \\
\text { FOXM1 }\end{array}$ & (114) \\
\hline
\end{tabular}


TABLE 2 | Continued

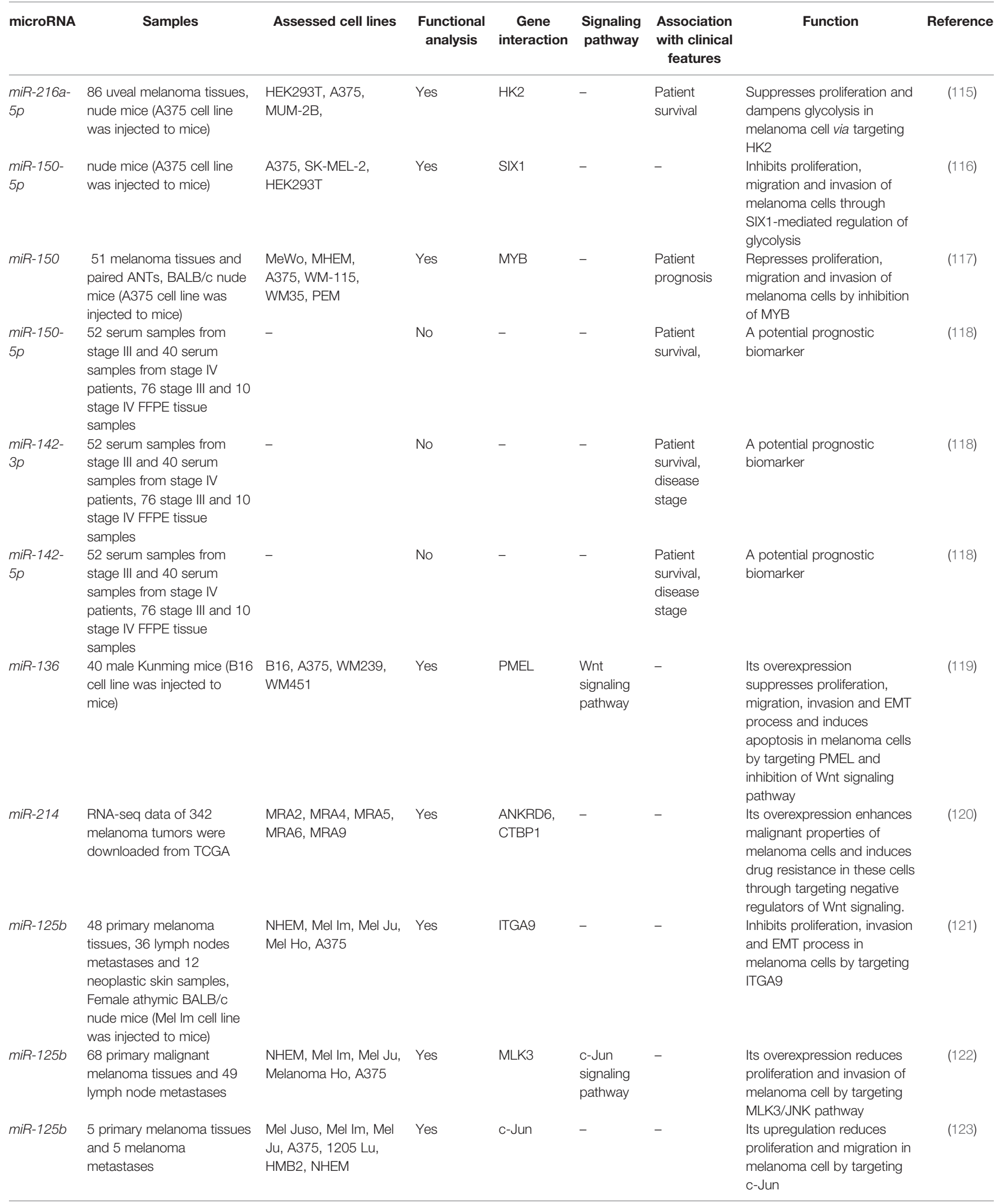


TABLE 2 | Continued

\begin{tabular}{|c|c|c|c|c|c|c|c|c|}
\hline microRNA & Samples & Assessed cell lines & $\begin{array}{l}\text { Functional } \\
\text { analysis }\end{array}$ & $\begin{array}{c}\text { Gene } \\
\text { interaction }\end{array}$ & $\begin{array}{l}\text { Signaling } \\
\text { pathway }\end{array}$ & $\begin{array}{l}\text { Association } \\
\text { with clinical } \\
\text { features }\end{array}$ & Function & Reference \\
\hline$m i R-125 b$ & - & $\begin{array}{l}\text { IGR, SK-Mel28, SK- } \\
\text { Mel25, SK-Mel5, } \\
\text { MelJuso, SM, MeWo }\end{array}$ & Yes & VDR & $\begin{array}{l}\text { vitamin D } \\
\text { signaling }\end{array}$ & - & $\begin{array}{l}\text { Influences VDR expression } \\
\text { and resistance of melanoma } \\
\text { cell lines to } 1,25(\mathrm{OH})(2) \mathrm{D}(3)\end{array}$ & $(124)$ \\
\hline$m i R-125 b$ & $\begin{array}{l}65 \text { primary melanoma } \\
\text { tissues and } 67 \text { melanoma } \\
\text { metastases }\end{array}$ & $\begin{array}{l}\text { A375, SKMEL-147, } \\
451 \mathrm{Lu}\end{array}$ & No & - & - & $\begin{array}{l}\text { Patient } \\
\text { survival, } \\
\text { Breslow } \\
\text { thickness, } \\
\text { ulceration, } \\
\text { Mitosis } / \mathrm{mm}^{2} \text {, } \\
\text { growth } \\
\text { phase, }\end{array}$ & $\begin{array}{l}\text { Can be a potential } \\
\text { prognostic biomarker }\end{array}$ & (125) \\
\hline miR-596 & $\begin{array}{l}\text { FFPE tissues specimens of } \\
36 \text { melanomas and } 22 \text { nevi }\end{array}$ & $\begin{array}{l}\text { A375, SK-Mel-19, } \\
\text { A2058, Malme-3M, } \\
\text { SK-Mel-12, SK-Mel-2, } \\
\text { Malme-3 }\end{array}$ & Yes & $\begin{array}{l}\text { MEK1, } \\
\text { MCL1, } \\
\text { BCL2L1 }\end{array}$ & $\begin{array}{l}\text { MAPK/ } \\
\text { ERK } \\
\text { signaling } \\
\text { pathway }\end{array}$ & $\begin{array}{l}\text { Poor overall } \\
\text { survival }\end{array}$ & $\begin{array}{l}\text { Its overexpression reduces } \\
\text { proliferation, migration and } \\
\text { invasion and stimulates } \\
\text { apoptosis through targeting } \\
\text { MEK1, MCL1 and BCL2L1 } \\
\text { and regulation of MAPK/ } \\
\text { ERK and apoptotic } \\
\text { pathways }\end{array}$ & $(126)$ \\
\hline $\operatorname{miR}-137$ & - & $\begin{array}{l}\text { A2058, WM793B, } \\
\text { HEMa-LP, HEK-293T }\end{array}$ & Yes & FGF9 & - & - & $\begin{array}{l}\text { Its enforced expression by } \\
\text { Propofol decreases } \\
\text { proliferation, migration and } \\
\text { invasion in melanoma cells } \\
\text { through inhibition of FGF9 } \\
\text { expression }\end{array}$ & $(127)$ \\
\hline $\begin{array}{l}\operatorname{miRNA-} \\
29 c\end{array}$ & $\begin{array}{l}30 \text { malignant melanoma } \\
\text { tissues and } 10 \text { paracancer } \\
\text { tissues }\end{array}$ & $\begin{array}{l}\text { A375, SK-MEL-1, SK- } \\
\text { MEL-5, HEMa-LP }\end{array}$ & Yes & CDK6 & - & $\begin{array}{l}\text { Poor } \\
\text { prognosis, } \\
\text { TNM stage }\end{array}$ & $\begin{array}{l}\text { Reduces cell proliferation } \\
\text { and induces cell cycle arrest } \\
\text { at G1 phase through } \\
\text { suppressing expression of } \\
\text { CDK6 }\end{array}$ & (128) \\
\hline $\begin{array}{l}\operatorname{miR}-488- \\
5 p\end{array}$ & $\begin{array}{l}\text { primary melanoma tumors, } \\
\text { melanoma metastases, } \\
\text { normal skin and nevi }\end{array}$ & Mel Im, 501mel, NHEM & Yes & DIXDC1 & $\begin{array}{l}\text { Wnt//- } \\
\text { catenin } \\
\text { signaling } \\
\text { pathway }\end{array}$ & - & $\begin{array}{l}\text { Has a tumor suppressive } \\
\text { role. Its overexpression } \\
\text { represses proliferation and } \\
\text { migration and induces } \\
\text { apoptosis in melanoma cells }\end{array}$ & (129) \\
\hline $\begin{array}{l}\operatorname{miR}-488- \\
3 p\end{array}$ & $\begin{array}{l}20 \text { malignant melanoma } \\
\text { tissues and ANTs, } 12 \text { male } \\
\text { Nu/Nu mice }\end{array}$ & $\begin{array}{l}\text { A375, B16, SK-MEL- } \\
\text { 28, WM451, HEMn-LP }\end{array}$ & Yes & PRKDC & - & - & $\begin{array}{l}\text { Its ectopic expression } \\
\text { sensitizes melanoma cells to } \\
\text { cisplatin via targeting } \\
\text { PRKDC }\end{array}$ & $(130)$ \\
\hline miR-675 & $\begin{array}{l}21 \text { melanoma tissues and } \\
\text { ANTs }\end{array}$ & $\begin{array}{l}\text { A375, A2058, HT144, } \\
\text { SK-MEL-28, HEM }\end{array}$ & Yes & MTDH & - & - & $\begin{array}{l}\text { Has a tumor suppressive } \\
\text { role. Its overexpression } \\
\text { inhibits proliferation and } \\
\text { invasion in melanoma cells } \\
\text { partly by targeting MTDH }\end{array}$ & (131) \\
\hline miR-622 & $\begin{array}{l}\text { Primary tumor and } \\
\text { metastatic tumor tissue, } \\
\text { male athymic nu/nu mice } \\
\text { (Mel Im cell line was injected } \\
\text { to mice) }\end{array}$ & $\begin{array}{l}\text { Mel Juso, Mel Ei, } \\
\text { Htz19, Mel Im, NHEM }\end{array}$ & Yes & KRAS & - & $\begin{array}{l}\text { Patient } \\
\text { survival }\end{array}$ & $\begin{array}{l}\text { Its re-expression suppresses } \\
\text { proliferation, migration and } \\
\text { clonogenicity in melanoma } \\
\text { cells. }\end{array}$ & (132) \\
\hline miR-92 & $\begin{array}{l}\text { Female } \mathrm{C} 57 \mathrm{BI} / 6 \text { mice (B16- } \\
\text { F10 cell line was injected to } \\
\text { mice) }\end{array}$ & $\mathrm{B} 16-\mathrm{F} 10$ & Yes & $\begin{array}{l}\text { integrin } \alpha_{V} \\
\text { and } \alpha_{5}\end{array}$ & $\begin{array}{l}\text { TGF } \beta \\
\text { signaling } \\
\text { pathway }\end{array}$ & - & $\begin{array}{l}\text { Implicates in integrin } \\
\text { activation of TGF } \beta \text { in } \\
\text { melanoma cancer stem cells } \\
\text { that gives rise to } \\
\text { immunosuppressive tumor } \\
\text { microenvironment and } \\
\text { increased tumorigenesis }\end{array}$ & (133) \\
\hline$m i R-4487$ & $\begin{array}{l}86 \text { melanoma samples, } \\
\text { serum samples from } 130 \\
\text { normal controls and } 255\end{array}$ & - & No & - & - & $\begin{array}{l}\text { Diseases } \\
\text { stage, } \\
\text { survival }\end{array}$ & $\begin{array}{l}\text { A probable diagnostic } \\
\text { biomarker }\end{array}$ & (23) \\
\hline $\operatorname{miR}-4706$ & melanoma cases & - & No & - & - & & & (23) \\
\hline
\end{tabular}


TABLE 2 | Continued

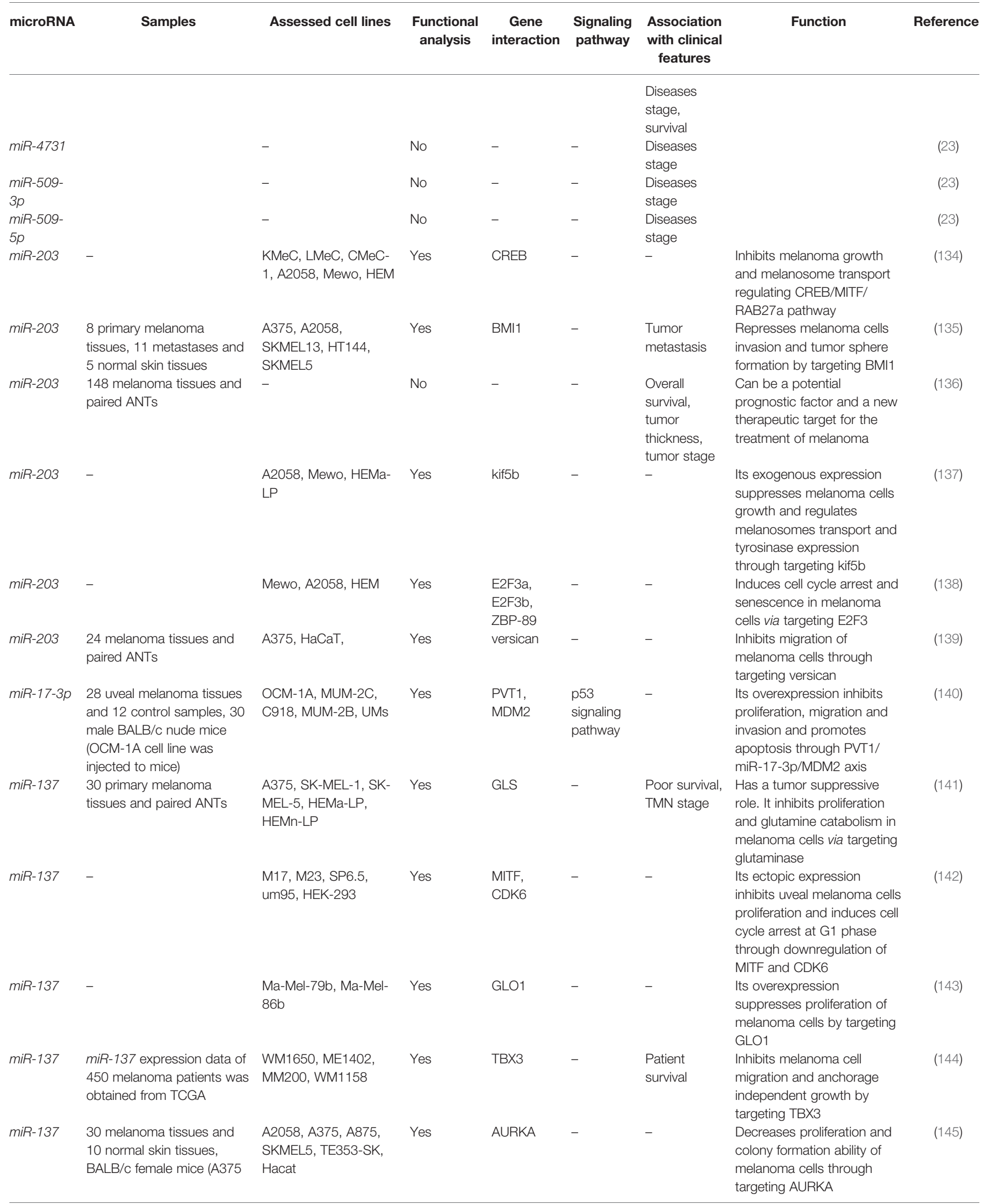


TABLE 2 | Continued

\begin{tabular}{|c|c|c|c|c|c|c|c|c|}
\hline microRNA & Samples & Assessed cell lines & $\begin{array}{l}\text { Functional } \\
\text { analysis }\end{array}$ & $\begin{array}{c}\text { Gene } \\
\text { interaction }\end{array}$ & $\begin{array}{l}\text { Signaling } \\
\text { pathway }\end{array}$ & $\begin{array}{l}\text { Association } \\
\text { with clinical } \\
\text { features }\end{array}$ & Function & Reference \\
\hline miR-137 & $\begin{array}{l}97 \text { melanoma tissues and } \\
\text { paired ANTs }\end{array}$ & - & No & - & - & $\begin{array}{l}\text { Patient } \\
\text { survival, TNM } \\
\text { stage, ulcer, } \\
\text { occurrence } \\
\text { site }\end{array}$ & $\begin{array}{l}\text { Its low expression is } \\
\text { associated with poor } \\
\text { prognosis in melanoma } \\
\text { patients. }\end{array}$ & (146) \\
\hline $\operatorname{miR}-137$ & - & $\begin{array}{l}\text { Ma-Mel-12, MaMel-20, } \\
\text { Ma-Mel-37b, Ma-Mel- } \\
\text { 57, Ma-Mel-73a, Ma- } \\
\text { Mel-79b, MaMel-86b, } \\
\text { SK-Mel-2, SK-Mel5 }\end{array}$ & Yes & PAK2 & - & - & $\begin{array}{l}\text { Suppresses proliferation of } \\
\text { melanoma cells via inhibiting } \\
\text { PAK2 }\end{array}$ & (147) \\
\hline $\operatorname{miR}-137$ & - & $\begin{array}{l}\text { WM278, A375, } \\
\text { HEK293 }\end{array}$ & Yes & CtBP1 & - & - & $\begin{array}{l}\text { Suppresses EMT process } \\
\text { and induces apoptosis in } \\
\text { melanoma cells through } \\
\text { targeting CtBP1 }\end{array}$ & (148) \\
\hline miR-137 & $\begin{array}{l}15 \text { melanoma tissues and } \\
15 \text { normal } \\
\text { pigmented nevus samples }\end{array}$ & $\begin{array}{l}\text { HaCaT, SK-MEL-1, } \\
\text { A375, WM451 }\end{array}$ & Yes & PIK3R3 & - & - & $\begin{array}{l}\text { Represses migration and } \\
\text { invasion of melanoma cells } \\
\text { via targeting PIK3R3 }\end{array}$ & (150) \\
\hline $\begin{array}{l}\operatorname{miR}-30 a \\
-5 p\end{array}$ & $\begin{array}{l}22 \text { malignant melanoma } \\
\text { tissues and ANTs, BALB/c } \\
\text { nude mice (A375 cell line } \\
\text { was injected to mice) }\end{array}$ & $\begin{array}{l}\text { A375, SK-HEP-1, SK- } \\
\text { MEL-1, MV3, HPM }\end{array}$ & Yes & SOX4 & - & - & $\begin{array}{l}\text { Inhibits melanoma cells } \\
\text { proliferation, migration and } \\
\text { invasion via targeting SOX4 }\end{array}$ & (151) \\
\hline $\operatorname{miR}-218$ & $\begin{array}{l}10 \text { primary melanoma } \\
\text { tissues, } 10 \text { lymph node } \\
\text { metastases and } 10 \text { benign } \\
\text { nevi samples }\end{array}$ & A375, SK-MEL-2 & Yes & $\begin{array}{l}\text { CIP2A, } \\
\text { BMl1 }\end{array}$ & & & $\begin{array}{l}\text { Inhibits proliferation, } \\
\text { migration and invasion in } \\
\text { melanoma cells by targeting } \\
\text { CIP2A, BMI1 }\end{array}$ & (152) \\
\hline $\begin{array}{l}\operatorname{miR}-24-1 \\
-5 p\end{array}$ & $\begin{array}{l}77 \text { malignant melanoma } \\
\text { tissues and paired ANTs }\end{array}$ & A375 & Yes & UBD & $\begin{array}{l}\text { JNK } \\
\text { signaling } \\
\text { pathway }\end{array}$ & & $\begin{array}{l}\text { Its overexpression gives rise } \\
\text { to promotion of autophagy } \\
\text { and apoptosis in melanoma } \\
\text { cells via targeting UBD and } \\
\text { activation of JNK signaling } \\
\text { pathway }\end{array}$ & (154) \\
\hline $\begin{array}{l}\text { miR-205- } \\
5 p\end{array}$ & $\begin{array}{l}6 \text { melanoma tissues and } 6 \\
\text { skin nevus samples }\end{array}$ & $\begin{array}{l}\text { HaCaT, A431, A375, } \\
\text { A2058 and SK-MEL-2 }\end{array}$ & Yes & TNFAIP8 & - & - & $\begin{array}{l}\text { Enhances apoptosis rate } \\
\text { and sensitizes melanoma } \\
\text { cells to vemurafenib through } \\
\text { targeting TNFAIP8 }\end{array}$ & (155) \\
\hline $\begin{array}{l}\text { miR-205- } \\
5 p\end{array}$ & $\begin{array}{l}32 \text { primary cutaneous } \\
\text { melanoma tissues and } 8 \\
\text { metastatic samples }\end{array}$ & - & No & - & - & $\begin{array}{l}\text { Distant } \\
\text { metastasis }\end{array}$ & $\begin{array}{l}\text { Can be a potential } \\
\text { biomarker of distant } \\
\text { metastases }\end{array}$ & (156) \\
\hline $\begin{array}{l}\text { miR-145- } \\
5 p \\
\text { miR-203- } \\
3 p\end{array}$ & $\begin{array}{l}32 \text { primary cutaneous } \\
\text { melanoma tissues and } 8 \\
\text { metastatic samples }\end{array}$ & - & No & - & - & $\begin{array}{l}\text { Breslow } \\
\text { thickness, } \\
\text { high Clark } \\
\text { level, } \\
\text { ulceration, } \\
\text { mitotic rate }\end{array}$ & $\begin{array}{l}\text { Can be potential markers of } \\
\text { aggressiveness in melanoma }\end{array}$ & (156) \\
\hline miR-205 & $\begin{array}{l}10 \text { primary melanoma } \\
\text { tissues, } 10 \text { metastatic } \\
\text { melanoma tissues and } 10\end{array}$ & $\begin{array}{l}\text { WM35, WM793, } \\
\text { WM115A, 1205Lu, } \\
\text { 293T }\end{array}$ & Yes & - & - & - & $\begin{array}{l}\text { Its enforced expression } \\
\text { reduces migration, motility }\end{array}$ & (157) \\
\hline
\end{tabular}


TABLE 2 | Continued

\begin{tabular}{|c|c|c|c|c|c|c|c|c|}
\hline microRNA & Samples & Assessed cell lines & $\begin{array}{l}\text { Functional } \\
\text { analysis }\end{array}$ & $\begin{array}{c}\text { Gene } \\
\text { interaction }\end{array}$ & $\begin{array}{l}\text { Signaling } \\
\text { pathway }\end{array}$ & $\begin{array}{l}\text { Association } \\
\text { with clinical } \\
\text { features }\end{array}$ & Function & Reference \\
\hline miR-205 & $\begin{array}{l}20 \text { primary melanoma } \\
\text { tissues, } 27 \text { metastatic } \\
\text { melanoma tissues and } 20 \\
\text { benign nevi }\end{array}$ & $\begin{array}{l}\text { WM3211, DO4, } \\
\text { WM278, 1205-Lu, } \\
\text { C8161.9, Normal } \\
\text { human melanocytes }\end{array}$ & Yes & E2F1, E2F5 & $\begin{array}{l}\text { AKT } \\
\text { signaling } \\
\text { pathway }\end{array}$ & - & $\begin{array}{l}\text { Its overexpression } \\
\text { suppresses proliferation and } \\
\text { colony formation and } \\
\text { induces apoptosis in } \\
\text { melanoma cell via targeting } \\
\text { E2F1 }\end{array}$ & (14) \\
\hline miR-205 & $\begin{array}{l}65 \text { primary melanoma } \\
\text { tissues and } 67 \text { melanoma } \\
\text { metastases }\end{array}$ & $\begin{array}{l}\text { A375, SKMEL-147, } \\
451 \mathrm{Lu}\end{array}$ & No & ZEB1 & - & $\begin{array}{l}\text { Patient } \\
\text { survival, } \\
\text { Breslow } \\
\text { thickness, } \\
\text { ulceration, } \\
\text { Mitosis/mm², } \\
\text { growth } \\
\text { phase, } \\
\text { Histological } \\
\text { type }\end{array}$ & $\begin{array}{l}\text { Influences invasive ability of } \\
\text { melanoma cells and can be } \\
\text { a potential prognostic } \\
\text { biomarker }\end{array}$ & (125) \\
\hline miR-205 & $\begin{array}{l}5 \text { high-invasive uveal } \\
\text { melanoma tissues, } 5 \text { low- } \\
\text { invasive uveal melanoma } \\
\text { tissues and } 5 \text { healthy } \\
\text { controls }\end{array}$ & OCM-1A, C918, 293T & Yes & NRP1 & - & - & $\begin{array}{l}\text { Its overexpression represses } \\
\text { proliferation and invasion of } \\
\text { melanoma cells via targeting } \\
\text { NRP1 }\end{array}$ & (158) \\
\hline $\begin{array}{l}\text { miR-145- } \\
5 p\end{array}$ & $\begin{array}{l}83 \text { melanoma samples and } \\
\text { paired ANTs, } 30 \text { male } \\
\text { BALB/c nude mice (CHL-1, } \\
\text { WMM917, or SK-mel-28 } \\
\text { cell lines were injected to } \\
\text { mice) }\end{array}$ & $\begin{array}{l}\text { HEK293T, SK-mel-28, } \\
\text { CHL-1, VMM917, } \\
\text { NHEM }\end{array}$ & Yes & NRAS & $\begin{array}{l}\text { MAPK and } \\
\text { PISK/AKT } \\
\text { signaling } \\
\text { pathways }\end{array}$ & $\begin{array}{l}\text { Tumor } \\
\text { thickness, } \\
\text { NRAS } \\
\text { mutation, } \\
\text { tumor stage }\end{array}$ & $\begin{array}{l}\text { Its high expression inhibit } \\
\text { proliferation, migration and } \\
\text { invasion and promotes } \\
\text { apoptosis in VMM917 and } \\
\mathrm{CHL}-1 \text { melanoma cells } \\
\text { through targeting NRAS }\end{array}$ & (159) \\
\hline miR-195 & $\begin{array}{l}341 \text { matched mRNA-Seq } \\
\text { and miRNA-Seq tumor } \\
\text { samples, along with one } \\
\text { normal sample for each } \\
\text { data set were obtained from } \\
\text { TCGA }\end{array}$ & $\begin{array}{l}\text { SK-MEL-5, SK-MEL- } \\
\text { 19, SK-MEL-37, SK- } \\
\text { MEL-147, UACC-62, } \\
\text { WM35, WM793B, } \\
\text { WM1366, WM1552C, } \\
\text { WM1617, Lox10, } \\
\text { MZ2Mel, HaCat, NGM }\end{array}$ & Yes & PHB1 & - & - & $\begin{array}{l}\text { Its upregulation results in } \\
\text { decreased cell proliferation } \\
\text { and high cytotoxic effects of } \\
\text { cisplatin and temozolomide } \\
\text { on melanoma cells }\end{array}$ & (162) \\
\hline miR-211 & $\begin{array}{l}\text { Male BALB/c nude mice } \\
\text { (SK-MEL-28 cell line was } \\
\text { injected) }\end{array}$ & A375, SK-MEL-28 & Yes & - & - & $\begin{array}{l}\text { Poor } \\
\text { prognosis, } \\
\text { tumor } \\
\text { thickness, } \\
\text { AJCC stage }\end{array}$ & $\begin{array}{l}\text { Its upregulation sensitizes } \\
\text { melanoma cells to cisplatin } \\
\text { and increases cisplatin } \\
\text { anticancer effect }\end{array}$ & (163) \\
\hline miR-211 & - & $\begin{array}{l}\text { A375, WM1552C, } \\
\text { HEM-I }\end{array}$ & Yes & PDK4 & - & - & $\begin{array}{l}\text { Acts as a metabolic switch } \\
\text { and sensitizes melanoma } \\
\text { cells to hypoxia through } \\
\text { targeting PDK4 }\end{array}$ & (164) \\
\hline miR-211 & $\begin{array}{l}6 \text { primary melanoma tissues } \\
\text { and } 24 \text { melanoma } \\
\text { metastases }\end{array}$ & $\begin{array}{l}\text { HEM-I, A375, G361, } \\
\text { LOX-IMV1, HT-144, } \\
\text { RPMI-7951, SK-MEL2, }\end{array}$ & Yes & KCNMA1 & - & - & $\begin{array}{l}\text { Its overexpression reduces } \\
\text { growth and invasion of } \\
\text { melanoma cells via targeting } \\
\text { KCNMA1 }\end{array}$ & (165) \\
\hline
\end{tabular}


TABLE 2 | Continued

\begin{tabular}{|c|c|c|c|c|c|c|c|c|}
\hline microRNA & Samples & Assessed cell lines & $\begin{array}{l}\text { Functional } \\
\text { analysis }\end{array}$ & $\begin{array}{c}\text { Gene } \\
\text { interaction }\end{array}$ & $\begin{array}{l}\text { Signaling } \\
\text { pathway }\end{array}$ & $\begin{array}{l}\text { Association } \\
\text { with clinical } \\
\text { features }\end{array}$ & Function & Reference \\
\hline miR-211 & - & $\begin{array}{l}\text { HM, WM115, A375, } \\
\text { SK-MEL-1 }\end{array}$ & Yes & RAB22A & - & - & $\begin{array}{l}\text { Regulates EMT process } \\
\text { through targeting RAB22A }\end{array}$ & (166) \\
\hline miR-211 & - & $\begin{array}{l}\text { HMV-I, HMV-II, } \\
\text { G-361, SK-MEL-28, } \\
\text { NHEM-L, NHEM-M, } \\
\text { NHEM-D, MM-EP, } \\
\text { MM-RU, MM-WK, } \\
\text { HEK-293 }\end{array}$ & Yes & PRAME & - & - & $\begin{array}{l}\text { Regulates PRAME } \\
\text { expression in melanoma } \\
\text { cells its overexpression } \\
\text { cause reduction in PRAME } \\
\text { expression }\end{array}$ & $(167)$ \\
\hline $\operatorname{miR}-211$ & - & $\begin{array}{l}61 \text { melanoma cell lines } \\
\text { (some of them include: } \\
\text { A2-A15, D4-D25, } \\
\text { ME1007, ME1402, } \\
\text { ME4405, ME10538, } \\
\text { Mel-FH, Mel-RM, Mel- } \\
\text { RMU, MM470, } \\
\text { MM537, MM629) }\end{array}$ & Yes & BRN2 & - & - & $\begin{array}{l}\text { Changes invasion capacity } \\
\text { of melanoma cells through } \\
\text { targeting BRN2 }\end{array}$ & (168) \\
\hline miR-211 & $\begin{array}{l}\text { miRNA expression was } \\
\text { derived for eleven } \\
\text { melanoma cell lines and } \\
\text { matched to samples } \\
\text { obtained from GEO }\end{array}$ & $\begin{array}{l}\text { WM3526, WM3682, } \\
\text { 451LU }\end{array}$ & Yes & NUAK1 & - & - & $\begin{array}{l}\text { Its upregulation inhibits } \\
\text { invasion and restores } \\
\text { adhesion through targeting } \\
\text { NUAK1 }\end{array}$ & (169) \\
\hline miR-211 & $\begin{array}{l}52 \text { cutaneous melanoma } \\
\text { tissues, } 41 \text { uveal melanoma } \\
\text { tissues and } 35 \text { normal skin } \\
\text { specimens }\end{array}$ & G361, GR-M, OCM-1 & Yes & $\mathrm{IL}-10 \mathrm{R} \alpha$ & - & - & $\begin{array}{l}\text { Its ectopic expression } \\
\text { decreases proliferation of all } \\
\text { melanoma cell lines through } \\
\text { targeting IL-10R } \alpha\end{array}$ & (95) \\
\hline miR-211 & - & $\begin{array}{l}\text { A375M, UACC62, } \\
\text { HeLa }\end{array}$ & Yes & $\begin{array}{l}\text { IGF2R, } \\
\text { TGFBR2, } \\
\text { NFAT5 }\end{array}$ & - & - & $\begin{array}{l}\text { Its overexpression inhibits } \\
\text { migration and invasion of } \\
\text { invasive melanoma cells }\end{array}$ & $(170)$ \\
\hline miR-375 & $\begin{array}{l}24 \text { melanoma tissues, } \\
\text { normal skin and nevi } \\
\text { samples }\end{array}$ & $\begin{array}{l}\text { HEM-I, HEK, WM793B, } \\
\text { WM278, WM1552C }\end{array}$ & Yes & - & - & - & $\begin{array}{l}\text { Its ectopic expression } \\
\text { suppresses proliferation } \\
\text { invasion, and cell motility } \\
\text { and induces changes in cell } \\
\text { shape in melanoma cells }\end{array}$ & (173) \\
\hline miR-328 & - & HEM, SK-MEL-1, A375 & Yes & TGFB2 & - & - & $\begin{array}{l}\text { Its overexpression represses } \\
\text { proliferation and induces cell } \\
\text { cycle arrest at G1 phase }\end{array}$ & (174) \\
\hline $\begin{array}{l}\operatorname{miR}-4633- \\
5 p\end{array}$ & $\begin{array}{l}56 \text { Primary human sinonasal } \\
\text { mucosal melanoma tissues }\end{array}$ & A375, M435S & Yes & - & $\begin{array}{l}\text { Akt } \\
\text { pathway }\end{array}$ & Metastasis & $\begin{array}{l}\text { Inhibits cell growth, invasion } \\
\text { and secretion of MMP2 in } \\
\text { melanoma }\end{array}$ & (175) \\
\hline miR-455 & $\begin{array}{l}20 \text { melanoma tissues and } \\
\text { paired ANTs }\end{array}$ & $\begin{array}{l}\text { SKMEL1, A375, } \\
\text { HT144, A2058, } \\
\text { HEK293T }\end{array}$ & Yes & IGF-1R & - & - & $\begin{array}{l}\text { Suppresses proliferation and } \\
\text { invasion in melanoma cells } \\
\text { via targeting IGF1R }\end{array}$ & (176) \\
\hline miR-145 & $\begin{array}{l}5 \text { high-invasive uveal } \\
\text { melanoma tissues, } 5 \text { low- } \\
\text { invasive uveal melanoma } \\
\text { tissues and } 5 \text { healthy } \\
\text { controls }\end{array}$ & OCM-1A, C918, 293T & Yes & NRP1 & - & - & $\begin{array}{l}\text { Represses proliferation and } \\
\text { invasion of melanoma cells } \\
\text { via targeting NRP1 }\end{array}$ & (158) \\
\hline $\operatorname{miR}-145$ & $\begin{array}{l}33 \text { oral canine malignant } \\
\text { melanoma tissues and } 11\end{array}$ & $\begin{array}{l}\text { KMeC, } \\
\mathrm{LMeC}, \mathrm{CMeC}-1 \text {, }\end{array}$ & Yes & $\begin{array}{l}\text { C-MYC, } \\
\text { FASCIN1 }\end{array}$ & - & - & $\begin{array}{l}\text { Inhibits proliferation and } \\
\text { migration in melanoma cells }\end{array}$ & (177) \\
\hline
\end{tabular}


TABLE 2 | Continued

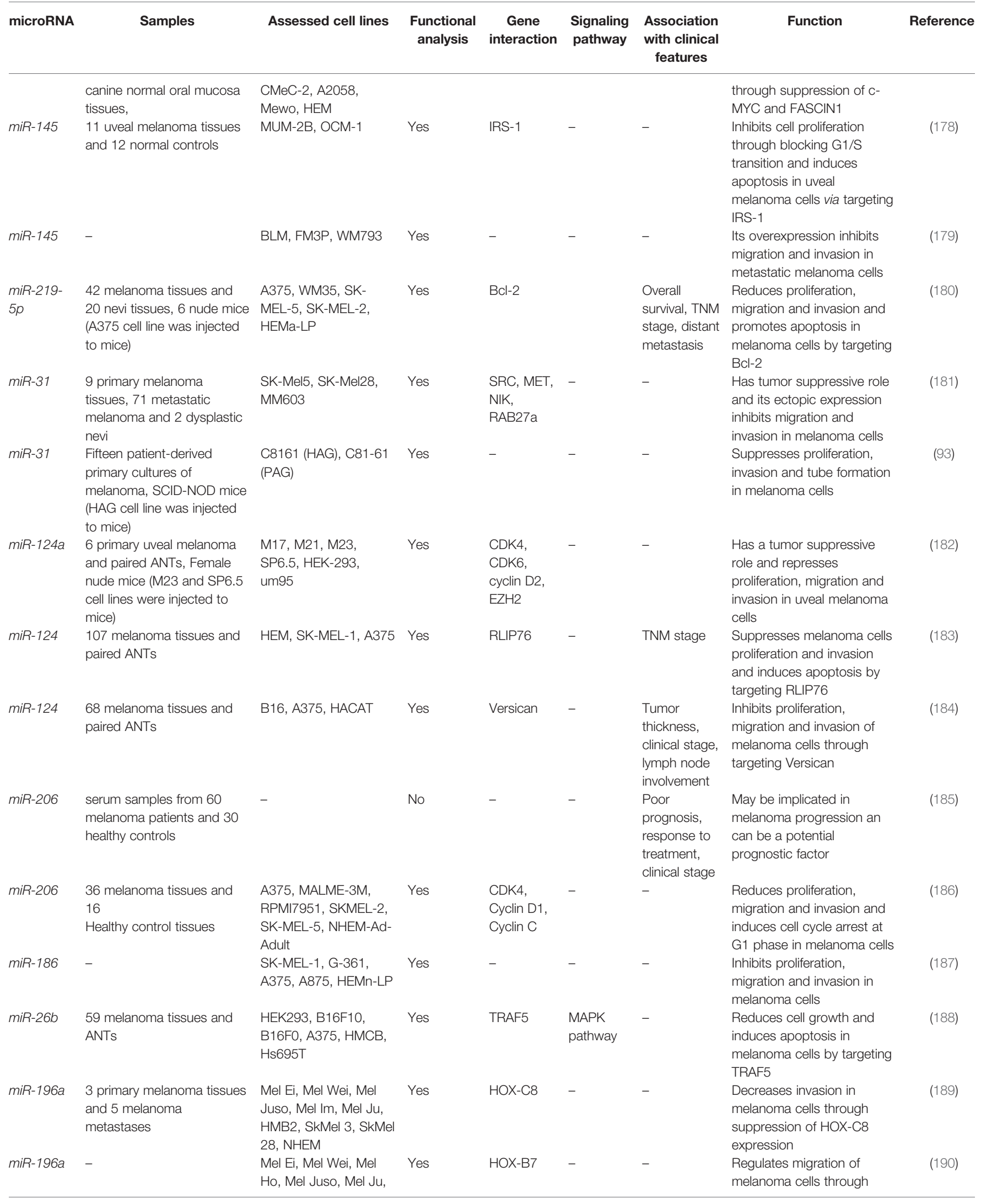


TABLE 2 | Continued

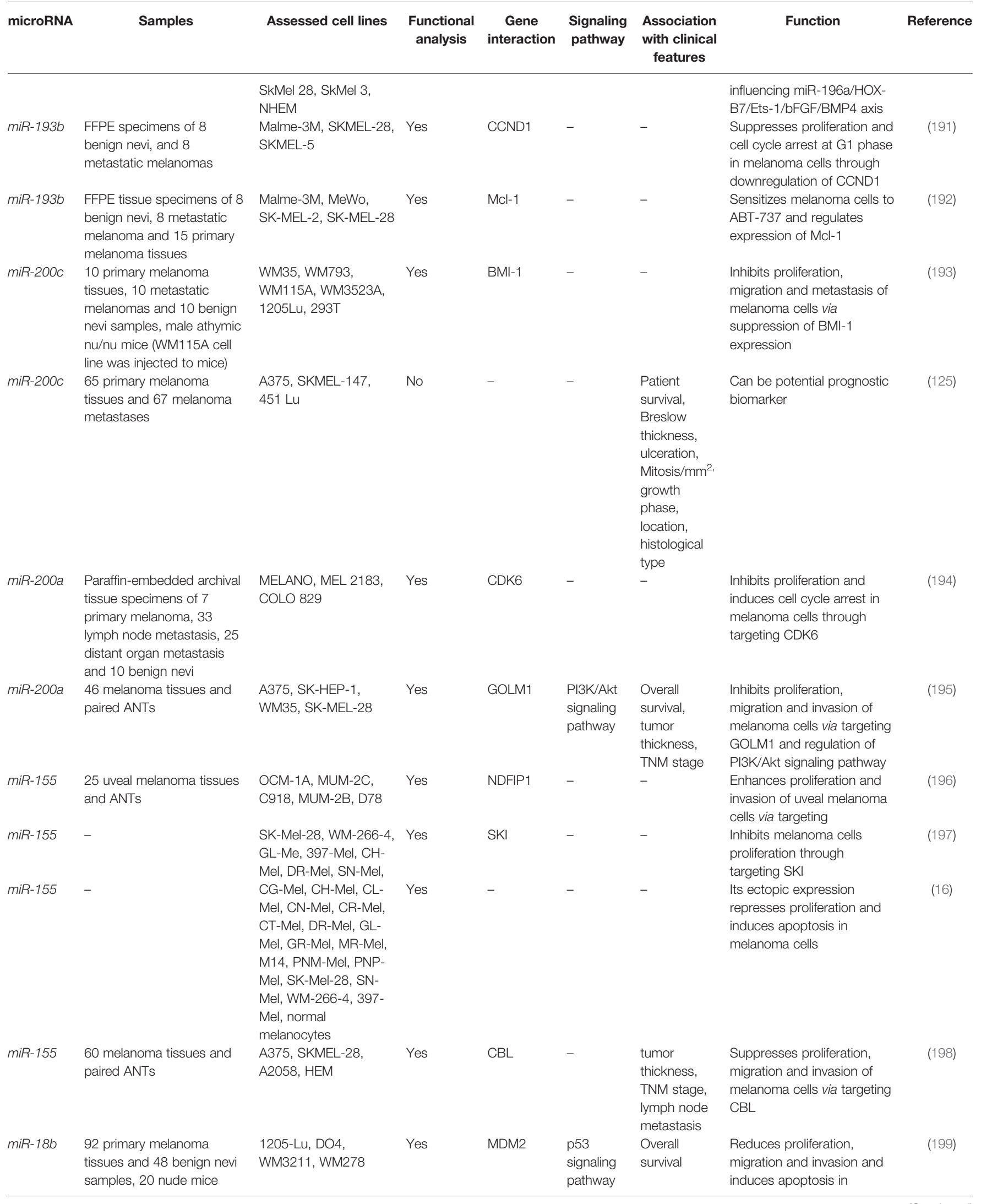


TABLE 2 | Continued

\begin{tabular}{|c|c|c|c|c|c|c|c|c|}
\hline microRNA & Samples & Assessed cell lines & $\begin{array}{l}\text { Functional } \\
\text { analysis }\end{array}$ & $\begin{array}{c}\text { Gene } \\
\text { interaction }\end{array}$ & $\begin{array}{l}\text { Signaling } \\
\text { pathway }\end{array}$ & $\begin{array}{l}\text { Association } \\
\text { with clinical } \\
\text { features }\end{array}$ & Function & Reference \\
\hline miR-18b & $\begin{array}{l}68 \text { melanoma tissues and } \\
\text { paired ANTs, } 6 \text { male BALB/ } \\
\text { C-nu/nu nude mice (B16 } \\
\text { cell line was injected to } \\
\text { mice) }\end{array}$ & $\begin{array}{l}\text { HEK293 cells, MM } \\
\text { B16, A375, HACAT }\end{array}$ & Yes & $\mathrm{HIF}-1 \alpha$ & - & $\begin{array}{l}\text { tumor } \\
\text { thickness, } \\
\text { tumor stage }\end{array}$ & $\begin{array}{l}\text { Inhibits glycolysis and cell } \\
\text { proliferation and induces cell } \\
\text { cycles arrest in melanoma } \\
\text { cells through targeting HIF- } \\
1 \alpha\end{array}$ & (200) \\
\hline miR-26a & - & $\begin{array}{l}\text { SK-MEL-28, HT-144, } \\
\text { HEK293, HEMNLP, } \\
\text { HEMNLP2, WM278, } \\
\text { WM852C, 1205Lu, } \\
\text { A375, RPMI7951 }\end{array}$ & Yes & SODD & - & - & $\begin{array}{l}\text { Decreases cell viability and } \\
\text { induces apoptosis in } \\
\text { melanoma cells through } \\
\text { targeting SODD. }\end{array}$ & (201) \\
\hline miR-26a & - & $\begin{array}{l}\text { A2058, A375, SK- } \\
\text { MEL-5, SK-MEL-28 }\end{array}$ & Yes & $\begin{array}{l}\text { Lin28B, } \\
\text { Zcchc11 }\end{array}$ & - & - & $\begin{array}{l}\text { Increases microRNA } \\
\text { synthesis by targeting } \\
\text { Lin28B and Zcchc } 11 \text { to } \\
\text { inhibit tumor growth and } \\
\text { metastasis }\end{array}$ & (202) \\
\hline miR-26a & $\begin{array}{l}\text { male C57BL/6 mice (B16- } \\
\text { F10 cell line was injected to } \\
\text { mice) }\end{array}$ & $\begin{array}{l}\text { WM1552C, SKMEL- } \\
\text { 28, B16-F10 }\end{array}$ & Yes & MITF & - & - & $\begin{array}{l}\text { Inhibits proliferation and } \\
\text { invasion of melanoma cells } \\
\text { via targeting MITF }\end{array}$ & (203) \\
\hline miR-9 & $\begin{array}{l}10 \text { primary melanoma } \\
\text { tissues and } 10 \text { metastases }\end{array}$ & $\begin{array}{l}\text { WM35, WM793, } \\
\text { WM115A, 1205Lu, } \\
\text { 293T }\end{array}$ & Yes & NF-kB1 & $\begin{array}{l}\text { NF-кB1- } \\
\text { Snail1 } \\
\text { signaling } \\
\text { pathway }\end{array}$ & - & $\begin{array}{l}\text { Reduces proliferation and } \\
\text { migration of melanoma cells } \\
\text { through regulation of NF- } \\
\text { кB1-Snail1 pathway. }\end{array}$ & (204) \\
\hline $\operatorname{miR}-9$ & $\begin{array}{l}24 \text { melanoma tissues and } \\
14 \text { benign nevi samples }\end{array}$ & $\begin{array}{l}\text { WM852, WM1791C, } \\
\text { WM8, FO-1, WM983A, } \\
\text { WM793, Daju, WM209 }\end{array}$ & Yes & RYBP & - & - & $\begin{array}{l}\text { Suppresses proliferation } \\
\text { migration and invasion in } \\
\text { melanoma cells through } \\
\text { targeting RYBP }\end{array}$ & (205) \\
\hline miR-9 & 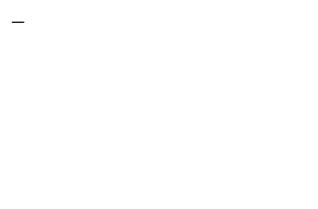 & $\begin{array}{l}\text { MUM-2B, C918, MUM- } \\
\text { 2C, OCM-1A }\end{array}$ & Yes & NF-kB1 & $\begin{array}{l}\mathrm{NF}-\kappa \mathrm{B} 1 \\
\text { signaling } \\
\text { pathway }\end{array}$ & - & $\begin{array}{l}\text { Suppresses migration and } \\
\text { invasion of uveal melanoma } \\
\text { cells via targeting cells NF- } \\
\kappa B 1 \text { and downregulation of } \\
\text { the NF-kB1 signaling } \\
\text { pathway }\end{array}$ & (206) \\
\hline let-7b & $\begin{array}{l}10 \text { primary melanoma } \\
\text { tissues and } 10 \text { benign } \\
\text { melanocytic nevi }\end{array}$ & SK-Mel-147, G361 & Yes & $\begin{array}{l}\text { cyclin D1, } \\
\text { cyclin D3, } \\
\text { cyclin A, } \\
\text { Cdk-4 }\end{array}$ & - & - & $\begin{array}{l}\text { Suppresses progression of } \\
\text { cell cycle and anchorage- } \\
\text { independent growth in } \\
\text { melanoma }\end{array}$ & (85) \\
\hline let-7b & $\begin{array}{l}16 \text { melanoma tissues and } 8 \\
\text { normal } \\
\text { tissues }\end{array}$ & $\begin{array}{l}\text { s SK-mel-28, A375, } \\
\text { A2058, HaCaT }\end{array}$ & Yes & UHRF1 & - & - & $\begin{array}{l}\text { Suppresses proliferation of } \\
\text { melanoma cell by targeting } \\
\text { UHRF1 }\end{array}$ & (209) \\
\hline let-7b & - & OCM1, OM431 & Yes & cyclin D1 & - & - & $\begin{array}{l}\text { Sensitizes radioresistance } \\
\text { uveal melanoma cells to } \\
\text { radiotherapy by targeting } \\
\text { cyclin D1 }\end{array}$ & (210) \\
\hline let-7b & $\begin{array}{l}106 \text { mucosal melanoma } \\
\text { tissues, mucosal nevi } \\
\text { Female NOD/SCID (HMVII } \\
\text { cell line was injected to } \\
\text { mice) }\end{array}$ & HMVII, GAK, 293T & Yes & $\begin{array}{l}\text { MTDH, } \\
\text { CALU }\end{array}$ & - & $\begin{array}{l}\text { Patient } \\
\text { survival, } \\
\text { ECOG score }\end{array}$ & $\begin{array}{l}\text { Suppresses melanoma cells } \\
\text { proliferation, migration, } \\
\text { invasion and induces } \\
\text { apoptosis through targeting } \\
\text { MTDH and CALU }\end{array}$ & (211) \\
\hline let-7c & $\begin{array}{l}106 \text { mucosal melanoma } \\
\text { tissues, mucosal nevi } \\
\text { Female NOD/SCID (HMVII }\end{array}$ & HMVII, GAK, 293T & Yes & $\begin{array}{l}\text { MTDH, } \\
\text { CALU }\end{array}$ & - & $\begin{array}{l}\text { Patient } \\
\text { survival, } \\
\text { ECOG score }\end{array}$ & $\begin{array}{l}\text { Suppresses melanoma cells } \\
\text { proliferation, migration, } \\
\text { invasion and induces }\end{array}$ & (211) \\
\hline
\end{tabular}


TABLE 2 | Continued

\begin{tabular}{|c|c|c|c|c|c|c|c|c|}
\hline microRNA & Samples & Assessed cell lines & $\begin{array}{l}\text { Functional } \\
\text { analysis }\end{array}$ & $\begin{array}{c}\text { Gene } \\
\text { interaction }\end{array}$ & $\begin{array}{l}\text { Signaling } \\
\text { pathway }\end{array}$ & $\begin{array}{c}\text { Association } \\
\text { with clinical } \\
\text { features }\end{array}$ & Function & Reference \\
\hline let-7a & - & $\begin{array}{l}\text { Mel Im, Mel Wei, Mel } \\
\text { Juso, Mel Ei, Mel Ho, } \\
\text { Mel Ju, HMB2, SK-Mel } \\
28\end{array}$ & Yes & integrin $\beta 3$ & - & - & $\begin{array}{l}\text { Its overexpression } \\
\text { decreases invasive ability of } \\
\text { melanoma cells through } \\
\text { downregulation of integrin } \\
\text { } 3\end{array}$ & $(86)$ \\
\hline $\begin{array}{l}\text { miR-330- } \\
3 p\end{array}$ & $\begin{array}{l}77 \text { melanoma tissues and } \\
38 \text { Normal skin tissues, }\end{array}$ & SK-MEL-2, UACC903 & Yes & TPX2 & - & - & $\begin{array}{l}\text { Suppresses proliferation of } \\
\text { melanoma cells through } \\
\text { negative regulation of TPX2 }\end{array}$ & (212) \\
\hline $\begin{array}{l}\text { miR-330- } \\
5 p\end{array}$ & $\begin{array}{l}26 \text { primary melanoma } \\
\text { tissues and } 26 \text { matched } \\
\text { non-tumor tissues }\end{array}$ & HEMn-LP, A375, A875 & Yes & $\begin{array}{l}\text { TYR, } \\
\text { PDIA3 }\end{array}$ & - & - & $\begin{array}{l}\text { Represses proliferation, } \\
\text { migration and invasion of } \\
\text { melanoma cells via } \\
\text { suppression of TYR and } \\
\text { PDIA3 expression }\end{array}$ & (213) \\
\hline $\operatorname{miR}-144$ & $\begin{array}{l}5 \text { uveal melanoma tissues } \\
\text { and } 5 \text { uveal normal tissues }\end{array}$ & $\begin{array}{l}\text { MUM-2B, C918, MUM- } \\
\text { 2C, OCM-1A, D78 }\end{array}$ & Yes & c-Met & - & - & $\begin{array}{l}\text { Inhibit proliferation and } \\
\text { migration in uveal melanoma } \\
\text { cells via targeting c-Met }\end{array}$ & (215) \\
\hline $\operatorname{miR}-144$ & $\begin{array}{l}26 \text { uveal melanoma tissues } \\
\text { and normal choroid samples }\end{array}$ & $\begin{array}{l}\text { MEL270, OMM2.5, } \\
\text { UPMM3, UPMM2 }\end{array}$ & Yes & $\begin{array}{l}\text { ADAM10, } \\
\text { C-Met }\end{array}$ & - & - & $\begin{array}{l}\text { Suppresses proliferation, } \\
\text { migration and cell cycle } \\
\text { progression in melanoma } \\
\text { cells through targeting } \\
\text { ADAM10 and c-Met }\end{array}$ & (216) \\
\hline miR-122 & $\begin{array}{l}26 \text { uveal melanoma tissues } \\
\text { and normal choroid samples }\end{array}$ & $\begin{array}{l}\text { MEL270, OMM2.5, } \\
\text { UPMM3, UPMM2 }\end{array}$ & Yes & $\begin{array}{l}\text { ADAM10, } \\
\text { C-Met }\end{array}$ & - & - & $\begin{array}{l}\text { Suppresses proliferation, } \\
\text { migration and cell cycle } \\
\text { progression in melanoma } \\
\text { cells through targeting } \\
\text { ADAM10 and c-Met }\end{array}$ & (216) \\
\hline $\begin{array}{l}\text { miR-542- } \\
3 p\end{array}$ & $\begin{array}{l}24 \text { melanoma tissues and } \\
12 \text { non-neoplastic skin } \\
\text { tissues, C57BL/6J mice } \\
\text { (B16F10 cell line was } \\
\text { injected to mice) }\end{array}$ & $\begin{array}{l}\text { A375, SK-MEL-19, SK- } \\
\text { MEL-28, WM451, } \\
\text { B16F10 }\end{array}$ & Yes & PIM1 & - & - & $\begin{array}{l}\text { Inhibits migration, invasion } \\
\text { and EMT process in } \\
\text { melanoma cells via targeting } \\
\text { PIM1 }\end{array}$ & (219) \\
\hline $\begin{array}{l}\text { miR-625- } \\
5 p\end{array}$ & $\begin{array}{l}\text { Primary melanoma tissues } \\
\text { and normal tissues }\end{array}$ & $\begin{array}{l}\text { A2085, A375, A875, } \\
\text { Mel-RM, } \\
\text { M14, M21, WM35, } \\
\text { HFE }\end{array}$ & Yes & PKM2 & - & $\begin{array}{l}\text { TNM stage, } \\
\text { tumor size, } \\
\text { poor } \\
\text { differentiation }\end{array}$ & $\begin{array}{l}\text { Inhibits melanoma cells } \\
\text { proliferation and glycolysis } \\
\text { and sensitizes these cell to } \\
\text { BRAF inhibitor via targeting } \\
\text { PKM2 }\end{array}$ & (220) \\
\hline $\begin{array}{l}\text { miR-339- } \\
3 p\end{array}$ & $\begin{array}{l}\text { NSG mice (A375 cell line } \\
\text { was injected to mice) }\end{array}$ & $\begin{array}{l}\text { A375, WM266.4, } \\
\text { WM115 }\end{array}$ & Yes & MCL1 & - & - & $\begin{array}{l}\text { Reduces invasive ability and } \\
\text { metastasis in melanoma } \\
\text { cells through targeting MCL1 }\end{array}$ & (221) \\
\hline $\begin{array}{l}\text { miR-590- } \\
5 p\end{array}$ & $\begin{array}{l}\text { female athymic Balb/C nude } \\
\text { mice (A2058 cell line was } \\
\text { injected to mice) }\end{array}$ & $\begin{array}{l}\text { A2058, A375, HEMa- } \\
\text { LP, 293, HM }\end{array}$ & Yes & YAP1 & - & - & $\begin{array}{l}\text { Reduces proliferation and } \\
\text { induces apoptosis in } \\
\text { melanoma cells via } \\
\text { downregulation of YAP1 }\end{array}$ & (222) \\
\hline $\begin{array}{l}\text { miR-768- } \\
3 p\end{array}$ & - & $\begin{array}{l}\text { MM200, Mel-CV, IgR3, } \\
\text { Mel-RMu, Sk-Mel-28, } \\
\text { Me1007, Mel-JD, Mel- }\end{array}$ & Yes & elF4E & - & - & $\begin{array}{l}\text { Suppresses cell proliferation } \\
\text { and survival and reduces } \\
\text { nascent protein synthesis in }\end{array}$ & (223) \\
\hline
\end{tabular}


TABLE 2 | Continued

\begin{tabular}{|c|c|c|c|c|c|c|c|c|}
\hline microRNA & Samples & Assessed cell lines & $\begin{array}{l}\text { Functional } \\
\text { analysis }\end{array}$ & $\begin{array}{c}\text { Gene } \\
\text { interaction }\end{array}$ & $\begin{array}{l}\text { Signaling } \\
\text { pathway }\end{array}$ & $\begin{array}{l}\text { Association } \\
\text { with clinical } \\
\text { features }\end{array}$ & Function & Reference \\
\hline $\begin{array}{l}\text { miR- } \\
451 a .1\end{array}$ & $\begin{array}{l}105 \text { melanoma tissues and } \\
101 \text { normal skin tissues }\end{array}$ & $\begin{array}{l}\text { A2058, A375P, C32, } \\
\text { A375SM, WM983A, } \\
\text { WM278, WM35, } \\
\text { WM1552C }\end{array}$ & Yes & CAB39 & - & - & $\begin{array}{l}\text { Inhibits migration and } \\
\text { invasion of melanoma cells } \\
\text { (this effect is not mediated } \\
\text { by CAB39) }\end{array}$ & (224) \\
\hline miR-493 & $\begin{array}{l}52 \text { melanoma tissues and } \\
\text { paired ANTs }\end{array}$ & $\begin{array}{l}\text { PEM, SK-MEL-28, } \\
\text { WM-115, UACC257, } \\
\text { A375, A7, MeWo, } \\
\text { NHEM }\end{array}$ & Yes & IRS4 & - & - & $\begin{array}{l}\text { Suppresses proliferation and } \\
\text { cell cycle progression in } \\
\text { melanoma cells through } \\
\text { targeting IRS4 }\end{array}$ & (226) \\
\hline miR-516b & $\begin{array}{l}211 \text { primary melanoma } \\
\text { tissues, NOD/Shi-scid/lL- } \\
2 R \text { rull (NOG, Taconic) mice } \\
\text { ( } 451 \text { Lu cell line was injected } \\
\text { to mice) }\end{array}$ & $\begin{array}{l}\text { 501MEL, 451Lu, } \\
\text { WM1361a, SK-MEL- } \\
\text { 147, SK-MEL-173, SK- } \\
\text { MEL-28 }\end{array}$ & Yes & - & - & $\begin{array}{l}\text { Tumor } \\
\text { thickness }\end{array}$ & $\begin{array}{l}\text { Suppresses tumor growth } \\
\text { and metastasis }\end{array}$ & (227) \\
\hline miR-194 & $\begin{array}{l}60 \text { melanoma tissues and } \\
\text { paired ANTs }\end{array}$ & A375, A875 & Yes & GEF-H1 & - & TNM stages & $\begin{array}{l}\text { Inhibits proliferation and } \\
\text { metastasis of melanoma } \\
\text { cells through suppression of } \\
\text { GEF-H1/RhoA pathway }\end{array}$ & (228) \\
\hline miR-194 & $\begin{array}{l}24 \text { melanoma tissues and } \\
\text { paired ANTs, }\end{array}$ & SK-Mel2, & Yes & - & $\begin{array}{l}\text { PI3K/AKT/ } \\
\text { FoxO3a } \\
\text { and p53/ } \\
\text { p21 } \\
\text { signaling } \\
\text { pathways }\end{array}$ & $\begin{array}{l}\text { Patient } \\
\text { survival }\end{array}$ & $\begin{array}{l}\text { Inhibits cell proliferation and } \\
\text { induces apoptosis through } \\
\text { regulation of PI3K/AKT/ } \\
\text { FoxO3a and p53/p21 } \\
\text { signaling pathways }\end{array}$ & (229) \\
\hline miR-1280 & $\begin{array}{l}37 \text { melanoma tissues and } \\
24 \text { benign nevi samples }\end{array}$ & $\begin{array}{l}\text { A375, Mamel66a, } \\
\text { Mamel103b, 1205-Lu, } \\
\text { C8161.9 }\end{array}$ & Yes & $\mathrm{Src}$ & - & - & $\begin{array}{l}\text { Suppresses proliferation, cell } \\
\text { cycle progression and } \\
\text { invasion and promotes } \\
\text { apoptosis in melanoma cells } \\
\text { via targeting Src }\end{array}$ & (231) \\
\hline miR-573 & $\begin{array}{l}11 \text { melanoma tissues and } \\
\text { paired ANTs, BABL/c nude } \\
\text { mice (A375, SK-MEL-2 cell } \\
\text { lines were injected to mice) }\end{array}$ & A375, SK-MEL-2 & Yes & MCAM & - & - & $\begin{array}{l}\text { Suppresses proliferation and } \\
\text { invasion of melanoma cells } \\
\text { via targeting MCAM }\end{array}$ & (232) \\
\hline $\begin{array}{l}\text { miR-33a- } \\
5 p\end{array}$ & $\begin{array}{l}29 \text { melanoma tissues and } \\
\text { ANTs, nude mice (SKMEL- } \\
28 \text { cell line was injected to } \\
\text { mice) }\end{array}$ & $\begin{array}{l}\text { SKMEL-28, A375, } \\
\text { WM35, SKMEL-1, } \\
\text { PIG1 }\end{array}$ & Yes & SNAI2 & $\begin{array}{l}\text { PI3K/AKT/ } \\
\text { mTOR } \\
\text { signaling } \\
\text { pathway }\end{array}$ & $\begin{array}{l}\text { Lymph node } \\
\text { metastasis, } \\
\text { tumor size, } \\
\text { STM stage }\end{array}$ & $\begin{array}{l}\text { Suppresses proliferation, } \\
\text { migration and invasion and } \\
\text { induces apoptosis in } \\
\text { melanoma cell through } \\
\text { targeting SNAI2 }\end{array}$ & (233) \\
\hline $\begin{array}{l}\text { miR-33a- } \\
5 p\end{array}$ & $\begin{array}{l}20 \text { melanoma and match } \\
\text { nevus tissues }\end{array}$ & $\begin{array}{l}\text { A375, WM35, WM451, } \\
\text { SK-MEL-1, HM }\end{array}$ & Yes & - & - & - & $\begin{array}{l}\text { Reduces proliferation and } \\
\text { promotes radiosensitivity by } \\
\text { suppressing glycolysis in } \\
\text { melanoma cells }\end{array}$ & (234) \\
\hline miR-зза & $\begin{array}{l}\text { Male BALB/C-nu/nu mice } \\
\text { (A375 cell line was injected } \\
\text { to mice) }\end{array}$ & $\begin{array}{l}\text { WM35, WM451, A375, } \\
\text { SK-MEL-1, HM }\end{array}$ & Yes & $\mathrm{HIF}-1 \alpha$ & - & - & $\begin{array}{l}\text { Inhibits proliferation, invasion } \\
\text { and metastasis in melanoma } \\
\text { cells via targeting HIF-1 } \alpha\end{array}$ & (235) \\
\hline
\end{tabular}


TABLE 2 | Continued

\begin{tabular}{|c|c|c|c|c|c|c|c|c|}
\hline microRNA & Samples & Assessed cell lines & $\begin{array}{l}\text { Functional } \\
\text { analysis }\end{array}$ & $\begin{array}{c}\text { Gene } \\
\text { interaction }\end{array}$ & $\begin{array}{l}\text { Signaling } \\
\text { pathway }\end{array}$ & $\begin{array}{c}\text { Association } \\
\text { with clinical } \\
\text { features }\end{array}$ & Function & Reference \\
\hline miR-33a & - & $\begin{array}{l}\text { SK-MEL-1, WM-115, } \\
\text { PEMI, PEM2 }\end{array}$ & Yes & PCTAIRE1 & - & - & $\begin{array}{l}\text { Suppresses proliferation and } \\
\text { colony formation ability of } \\
\text { melanoma cells through } \\
\text { targeting PCTAIRE1 }\end{array}$ & (236) \\
\hline$m i R-33 b$ & - & $\begin{array}{l}\text { WM35, WM451, SK- } \\
\text { MEL-1, HM, HEK293 }\end{array}$ & Yes & $H I F-1 \alpha$ & - & - & $\begin{array}{l}\text { Suppresses melanoma cells } \\
\text { proliferation and glycolysis } \\
\text { through targeting HIF- } 1 \alpha\end{array}$ & (237) \\
\hline miR-98 & $\begin{array}{l}20 \text { melanoma tissues and } \\
20 \text { normal nevi, } 80 \text { male } \\
\text { mice (B16-F1 cell line was } \\
\text { injected to mice) }\end{array}$ & B16-F1 & Yes & IL-6 & - & $\begin{array}{l}\text { Patient } \\
\text { survival, } \\
\text { tumor stage }\end{array}$ & $\begin{array}{l}\text { Suppresses migration and } \\
\text { metastasis of melanoma cell } \\
\text { through miR-98-IL-6- } \\
\text { negative feedback loop }\end{array}$ & (238) \\
\hline $\operatorname{miR}-425$ & $\begin{array}{l}\text { Melanoma tissues and } \\
\text { normal tissues }\end{array}$ & $\begin{array}{l}\text { A375, SK-MEL-28, } \\
\text { UACC257, WM-115, } \\
\text { NHEM }\end{array}$ & Yes & IGF-1 & $\begin{array}{l}\text { PI3K-Akt } \\
\text { signaling } \\
\text { pathway }\end{array}$ & - & $\begin{array}{l}\text { Suppresses proliferation and } \\
\text { metastasis of melanoma cell } \\
\text { via targeting IGF-1 and } \\
\text { inhibition of PI3K-Akt } \\
\text { signaling pathway }\end{array}$ & (239) \\
\hline $\operatorname{miR}-637$ & $\begin{array}{l}61 \text { melanoma tissues and } \\
\text { ANTs }\end{array}$ & $\begin{array}{l}\text { A375, SK-MEL-28, } \\
\text { Mel-RM, HaCaT }\end{array}$ & Yes & P-REX2a & $\begin{array}{l}\text { PTEN/AKT } \\
\text { signaling } \\
\text { pathway }\end{array}$ & $\begin{array}{l}\text { lymph node } \\
\text { metastasis, } \\
\text { TNM stage }\end{array}$ & $\begin{array}{l}\text { Inhibits proliferation and G1- } \\
\mathrm{S} \text { transition in melanoma } \\
\text { cells through targeting P- } \\
\text { REX2a }\end{array}$ & (241) \\
\hline miR-329 & $\begin{array}{l}36 \text { paraffin-embedded } \\
\text { melanoma tissues and } 10 \\
\text { pigmented nevi samples }\end{array}$ & $\begin{array}{l}\text { PEM, WM-115, A375, } \\
\text { A7, UACC257 }\end{array}$ & Yes & HMGB2 & $\begin{array}{l}\beta \text {-catenin } \\
\text { signaling } \\
\text { pathway }\end{array}$ & - & $\begin{array}{l}\text { Suppresses proliferation, } \\
\text { migration and invasion and } \\
\text { promotes apoptosis in } \\
\text { melanoma cell through } \\
\text { negative regulation of } \\
\text { HMGB2 }\end{array}$ & (242) \\
\hline $\begin{array}{l}\text { miR-579- } \\
3 p\end{array}$ & $\begin{array}{l}\text { FFPE samples from } 9 \text { stage } \\
\text { III/IV melanomas, } 10 \text { stage I/ } \\
\text { II melanomas, } 4 \text { dysplastic } \\
\text { nevi, } 10 \text { melanocytic nevi } \\
\text { and } 4 \text { patients before and } \\
\text { after BRAF inhibitor } \\
\text { treatment }\end{array}$ & $\begin{array}{l}\text { M14, LOX IMVI, COLO } \\
38, \text { MALME-3M, } \\
\text { SKMEL5, WM115, } \\
\text { WM266, M229, HEK- } \\
293\end{array}$ & Yes & $\begin{array}{l}\text { BRAF, } \\
\text { MDM2 }\end{array}$ & - & - & $\begin{array}{l}\text { Inhibits growth and } \\
\text { migration of melanoma cells, } \\
\text { induces apoptosis and } \\
\text { impairs drug resistance in } \\
\text { melanoma }\end{array}$ & (243) \\
\hline miR-664 & $\begin{array}{l}9 \text { melanoma and } 2 \text { BMN } \\
\text { tissues, } 10 \text { Nude mice } \\
\text { (A375 cell line was injected } \\
\text { to mice) }\end{array}$ & $\begin{array}{l}\text { A375.S2, A7, MeWo, } \\
\text { RPMI-7951, SK-MEL- } \\
\text { 5, SK-MEL-24, SK- } \\
\text { MEL-28, PEM }\end{array}$ & Yes & PLP2 & - & $\begin{array}{l}\text { Patient } \\
\text { survival }\end{array}$ & $\begin{array}{l}\text { Decreases proliferation and } \\
\text { tumorigenicity of melanoma } \\
\text { cells through targeting PLP2 }\end{array}$ & (245) \\
\hline miR-29a & - & $\begin{array}{l}\text { HACAT, HFF, A375, } \\
\text { Malme-3M, SK-MEL-2, } \\
\text { SK-MEL-5, M14 }\end{array}$ & Yes & Bmi1 & $\begin{array}{l}\text { Wnt/ } \beta- \\
\text { catenin } \\
\text { and NF- } \\
\kappa B \\
\text { signaling } \\
\text { pathways }\end{array}$ & - & $\begin{array}{l}\text { Suppresses cell growth, } \\
\text { migration and invasion in } \\
\text { melanoma cells and induces } \\
\text { apoptosis by targeting Bmi1 }\end{array}$ & (246) \\
\hline $\begin{array}{l}\text { miR-524- } \\
5 p\end{array}$ & $\begin{array}{l}\text { male NOD/SCID mice (SK- } \\
\text { Mel- } 19 \text { cell line was injected } \\
\text { to mice) }\end{array}$ & $\begin{array}{l}\text { HEK293, Malme-3M, } \\
\text { Malme-3, A375, SK- } \\
\text { Mel-19 }\end{array}$ & Yes & $\begin{array}{l}\text { BRAF, } \\
\text { ERK2 }\end{array}$ & $\begin{array}{l}\text { MAPK/ } \\
\text { ERK } \\
\text { signaling } \\
\text { pathway }\end{array}$ & - & $\begin{array}{l}\text { Inhibits proliferation and } \\
\text { migration of melanoma cells } \\
\text { through targeting BRAF and } \\
\text { ERK2 and inhibition of } \\
\text { MAPKVRK signaling } \\
\text { pathway }\end{array}$ & (247) \\
\hline $\operatorname{miR}-138$ & $\begin{array}{l}\text { Whole blood samples from } \\
5 \text { melanoma patients and } 6 \\
\text { healthy controls }\end{array}$ & A2058 & Yes & - & $\begin{array}{l}\text { PI3K/AKT/ } \\
\text { mTOR } \\
\text { signaling } \\
\text { pathway }\end{array}$ & $\begin{array}{l}\text { Patient } \\
\text { survival }\end{array}$ & $\begin{array}{l}\text { Suppresses cell proliferation } \\
\text { and induces apoptosis in } \\
\text { melanoma cells via inhibition }\end{array}$ & (248) \\
\hline
\end{tabular}


TABLE 2 | Continued

\begin{tabular}{|c|c|c|c|c|c|c|c|c|}
\hline microRNA & Samples & Assessed cell lines & $\begin{array}{l}\text { Functional } \\
\text { analysis }\end{array}$ & $\begin{array}{c}\text { Gene } \\
\text { interaction }\end{array}$ & $\begin{array}{l}\text { Signaling } \\
\text { pathway }\end{array}$ & $\begin{array}{c}\text { Association } \\
\text { with clinical } \\
\text { features }\end{array}$ & Function & Reference \\
\hline & & & & & & & $\begin{array}{l}\text { of PI3K/AKT/mTOR signaling } \\
\text { pathway }\end{array}$ & \\
\hline $\operatorname{miR}-138$ & - & WM451, HM & Yes & $\mathrm{HIF}-1 \alpha$ & - & - & $\begin{array}{l}\text { Inhibits melanoma cells } \\
\text { proliferation, invasion and } \\
\text { glycolysis through targeting } \\
\text { HIF- } 1 \alpha\end{array}$ & (249) \\
\hline miR-126 & $\begin{array}{l}108 \text { primary cutaneous } \\
\text { melanoma tissues, } 18 \\
\text { melanoma metastases and } \\
16 \text { dysplastic nevi samples }\end{array}$ & - & No & - & - & $\begin{array}{l}\text { Patient } \\
\text { survival, } \\
\text { Breslow } \\
\text { thickness, } \\
\text { tumor } \\
\text { ulceration, } \\
\text { tumor stage }\end{array}$ & $\begin{array}{l}\text { Can be an independent } \\
\text { prognostic factor for overall } \\
\text { survival }\end{array}$ & (251) \\
\hline $\begin{array}{l}\text { miR- } \\
126 \& 126^{*}\end{array}$ & $\begin{array}{l}\text { adult athymic nude mice } \\
\text { (A375M and Me665/1 cell } \\
\text { lines were injected to mice) }\end{array}$ & $\begin{array}{l}\text { A375M, A375, Me665/ } \\
\text { 1, NHEM, Me1007, } \\
\text { Mel501, WM983A, } \\
\text { Me1402/R, Me665/2, } \\
\text { GR-mel, ST-mel, }\end{array}$ & Yes & $\begin{array}{l}\text { ADAM9, } \\
\text { MMP7 }\end{array}$ & - & - & $\begin{array}{l}\text { Decrease proliferation, } \\
\text { invasion and chemotaxis of } \\
\text { melanoma cells through } \\
\text { targeting ADAM9 and MMP7 }\end{array}$ & (252) \\
\hline miR-377 & $\begin{array}{l}\text { FFPE tissues samples of } 6 \\
\text { primary cutaneous } \\
\text { melanoma and } 13 \text { benign } \\
\text { nevi }\end{array}$ & $\begin{array}{l}\text { mel33B1, mel-14PA, } \\
\text { mel-15AY, mel-526, } \\
\text { mel-624, NHEM }\end{array}$ & Yes & $\begin{array}{l}\text { E2F3, } \\
\text { MAP3K7 }\end{array}$ & $\begin{array}{l}\text { MAP3K7/ } \\
\text { NF-kB } \\
\text { signaling } \\
\text { pathway }\end{array}$ & - & $\begin{array}{l}\text { Decreases proliferative ability } \\
\text { and colony-forming } \\
\text { capability in melanoma cells }\end{array}$ & (253) \\
\hline $\begin{array}{l}\text { miR-139- } \\
5 p\end{array}$ & $\begin{array}{l}82 \text { malignant melanoma } \\
\text { tissues and } 30 \text { benign } \\
\text { skin disease tissues from } \\
\text { healthy controls }\end{array}$ & $\begin{array}{l}\text { PIG1, A375, SK-MEL- } \\
\text { 1, SKMEL-2, SK-MEL- } \\
\text { 5, SK-MEL-28 }\end{array}$ & Yes & IGF1R & $\begin{array}{l}\text { PI3K/AKT } \\
\text { signaling } \\
\text { pathway }\end{array}$ & - & $\begin{array}{l}\text { Inhibits cell proliferation, } \\
\text { migration and invasion and } \\
\text { promotes apoptosis through } \\
\text { targeting IGF1R }\end{array}$ & (254) \\
\hline miR-22 & $\begin{array}{l}48 \text { melanoma tissues and } \\
\text { paired ANTs, nude mice } \\
\text { (A375 cell line was injected } \\
\text { to mice) }\end{array}$ & $\begin{array}{l}\text { HEM, A375, SK-MEL- } \\
\text { 1, WM35, SK-MEL-28 }\end{array}$ & Yes & FMNL2 & $\begin{array}{l}\text { Wnt/ } \beta \text { - } \\
\text { Catenin } \\
\text { Signaling } \\
\text { Pathway }\end{array}$ & $\begin{array}{l}\text { Overall } \\
\text { survival, } \\
\text { tumor } \\
\text { thickness, } \\
\text { TNM stage }\end{array}$ & $\begin{array}{l}\text { Suppresses proliferation, } \\
\text { migration and invasion of } \\
\text { melanoma cells through } \\
\text { targeting FMNL2 }\end{array}$ & (257) \\
\hline $\begin{array}{l}\operatorname{miR}-3065- \\
5 p\end{array}$ & $\begin{array}{l}12 \text { primary melanoma and } 9 \\
\text { benign melanocytic tumors }\end{array}$ & BRO, SK-MEL1 & Yes & $\begin{array}{l}\text { HIPK1, } \\
\text { ITGA1 }\end{array}$ & - & - & $\begin{array}{l}\text { Induces cell cycle arrest at } \\
\text { G1 phases and inhibits } \\
\text { migration of melanoma cells }\end{array}$ & (258) \\
\hline $\begin{array}{l}\text { miR-204- } \\
5 p\end{array}$ & $\begin{array}{l}12 \text { primary melanoma and } 9 \\
\text { benign melanocytic tumors }\end{array}$ & BRO, SK-MEL1 & Yes & - & - & - & $\begin{array}{l}\text { Decreases proliferation, } \\
\text { invasion and colony } \\
\text { formation ability of } \\
\text { melanoma cells }\end{array}$ & (258) \\
\hline $\begin{array}{l}\text { miR-204- } \\
5 p\end{array}$ & $\begin{array}{l}30 \text { melanoma tissues and } \\
20 \text { benign nevi tissues, } 10 \\
\text { immunodeficient female } \\
\text { nude mice (A375 cell line } \\
\text { was injected to mice) }\end{array}$ & $\begin{array}{l}\text { A375, WM35, SK- } \\
\text { MEL-5, SK-MEL-2 }\end{array}$ & Yes & $\begin{array}{l}\text { MMP9, } \\
\text { BCL2 }\end{array}$ & - & $\begin{array}{l}\text { Overall } \\
\text { survival }\end{array}$ & $\begin{array}{l}\text { Inhibits proliferation, } \\
\text { migration and invasion and } \\
\text { induces apoptosis in } \\
\text { melanoma cells through } \\
\text { targeting MMP9 and BCL2 }\end{array}$ & (259) \\
\hline $\operatorname{miR}-610$ & $\begin{array}{l}105 \text { melanoma tissues and } \\
\text { ANTs, female BALB/c mice } \\
\text { (A375 and MV3 were } \\
\text { injected to mice) }\end{array}$ & $\begin{array}{l}\text { SK-MEL-1, A375, SK- } \\
\text { MEL-28, MV3, B16-F1, } \\
\text { HPM }\end{array}$ & Yes & LRP6 & - & $\begin{array}{l}\text { Patient } \\
\text { survival, } \\
\text { tumor stage, } \\
\text { tumor } \\
\text { thickness }\end{array}$ & $\begin{array}{l}\text { Represses cell proliferation, } \\
\text { cell cycle progression and } \\
\text { induces apoptosis in } \\
\text { melanoma cells by targeting } \\
\text { LRP6 }\end{array}$ & (260) \\
\hline
\end{tabular}


TABLE 2 | Continued

\begin{tabular}{|c|c|c|c|c|c|c|c|c|}
\hline microRNA & Samples & Assessed cell lines & $\begin{array}{l}\text { Functional } \\
\text { analysis }\end{array}$ & $\begin{array}{c}\text { Gene } \\
\text { interaction }\end{array}$ & $\begin{array}{l}\text { Signaling } \\
\text { pathway }\end{array}$ & $\begin{array}{l}\text { Association } \\
\text { with clinical } \\
\text { features }\end{array}$ & Function & Reference \\
\hline miR-3662 & $\begin{array}{l}80 \text { melanoma tissues and } \\
\text { paired ANTs, BALB/c nude } \\
\text { mice (A375 and OCM-1A } \\
\text { cell lines were injected to } \\
\text { mice) }\end{array}$ & A375, OCM-1A & Yes & ZEB1 & - & - & $\begin{array}{l}\text { Inhibits invasion and EMT } \\
\text { process in melanoma cell via } \\
\text { targeting ZEB1 }\end{array}$ & $(261)$ \\
\hline miR-331 & $\begin{array}{l}22 \text { melanoma tissues and } \\
\text { paired ANTs }\end{array}$ & $\begin{array}{l}\text { HEM, A375, A2058, } \\
\text { HT144, SK-MEL-1, } \\
\text { SK-MEL-28 }\end{array}$ & Yes & AEG-1 & $\begin{array}{l}\text { PTEN/AKT } \\
\text { signaling } \\
\text { pathway }\end{array}$ & - & $\begin{array}{l}\text { Suppresses proliferation and } \\
\text { invasion of melanoma cells } \\
\text { through targeting AEG-1 }\end{array}$ & $(262)$ \\
\hline $\begin{array}{l}\operatorname{miR}-149- \\
5 p\end{array}$ & $\begin{array}{l}\text { Melanoma tissues and } \\
\text { ANTs }\end{array}$ & $\begin{array}{l}\text { A2058, A375, HSC-1, } \\
\text { SK-37, SKMLE-1, } \\
\text { WM451, HaCaT }\end{array}$ & Yes & LRIG2 & - & - & $\begin{array}{l}\text { Reduces proliferation, colony } \\
\text { formation and induces } \\
\text { apoptosis in melanoma cells } \\
\text { through targeting LRIG2 }\end{array}$ & (263) \\
\hline $\begin{array}{l}\operatorname{miR}-338- \\
3 p\end{array}$ & $\begin{array}{l}60 \text { melanoma tissues and } \\
\text { paired ANTs, }\end{array}$ & A375, G361 & Yes & MACC1 & - & $\begin{array}{l}\text { clinical stage, } \\
\text { lymph node } \\
\text { metastasis }\end{array}$ & $\begin{array}{l}\text { Inhibits proliferation, } \\
\text { migration and invasion in } \\
\text { melanoma cells through } \\
\text { targeting MACC1 }\end{array}$ & (264) \\
\hline $\operatorname{miR}-4458$ & - & $\begin{array}{l}\text { A375, A2058, SK- } \\
\text { MEL-28, SK-MEL-2, } \\
\text { HEMa-LP }\end{array}$ & Yes & PBX3 & - & - & $\begin{array}{l}\text { Represses proliferation, } \\
\text { migration and induces } \\
\text { apoptosis in melanoma cells } \\
\text { via targeting PBX3 }\end{array}$ & (265) \\
\hline $\begin{array}{l}\operatorname{miR}-489- \\
3 p\end{array}$ & $\begin{array}{l}\text { nude mice (A375 cell line } \\
\text { was injected to mice) }\end{array}$ & A375, SK-MEL-2 & Yes & SIX1 & - & - & $\begin{array}{l}\text { Inhibits proliferation, } \\
\text { migration and invasion of } \\
\text { melanoma cells and } \\
\text { regulates glycolysis through } \\
\text { targeting SIX1 }\end{array}$ & $(266)$ \\
\hline $\operatorname{miR}-431$ & $\begin{array}{l}113 \text { melanoma tissues and } \\
\text { paired ANTs }\end{array}$ & $\begin{array}{l}\text { A875, HBL, 1205Lu, } \\
\text { A375, SK-MEL-1, } \\
\text { HEMa-LP, CHL-1 }\end{array}$ & Yes & $\mathrm{NOTCH} 2$ & - & $\begin{array}{l}\text { Overall } \\
\text { survival, } \\
\text { tumor stage, } \\
\text { ulceration }\end{array}$ & $\begin{array}{l}\text { Suppresses cell proliferation, } \\
\text { migration and invasion and } \\
\text { induces apoptosis in } \\
\text { melanoma cells through } \\
\text { targeting NOTCH2 }\end{array}$ & $(267)$ \\
\hline miR-134 & $\begin{array}{l}18 \text { melanoma tissues and } \\
\text { paired ANTs }\end{array}$ & $\begin{array}{l}\text { BT549, MB-231, MB- } \\
\text { 486, MCF7, SK-BR-3, } \\
\text { 293T }\end{array}$ & Yes & CTHCR1 & - & - & $\begin{array}{l}\text { Decreases proliferation, } \\
\text { migration, invasion and } \\
\text { induces cell cycle arrest and } \\
\text { apoptosis in melanoma cells } \\
\text { through downregulation of } \\
\text { CTHCR1 }\end{array}$ & (268) \\
\hline $\begin{array}{l}\operatorname{miR}-224- \\
5 p\end{array}$ & $\begin{array}{l}30 \text { uveal melanoma tissues } \\
\text { and paired ANTs }\end{array}$ & OCM-1A, HEK 293T & Yes & $\begin{array}{l}\text { PIK3R3, } \\
\text { AKT3 }\end{array}$ & - & - & $\begin{array}{l}\text { Suppresses proliferation, } \\
\text { migration and invasion of } \\
\text { melanoma cells via targeting } \\
\text { PIK3R3 and AKT3 }\end{array}$ & (269) \\
\hline $\begin{array}{l}\operatorname{miR}-140- \\
5 p\end{array}$ & $\begin{array}{l}25 \text { melanoma tissues and } \\
\text { paired ANTs, } 20 \text { adult } \\
\text { athymic nude mice (SK- } \\
\text { MEL- } 1 \text { cell line was injected } \\
\text { to mice) }\end{array}$ & $\begin{array}{l}\text { A375, A875, SK-MEL- } \\
5, \\
\text { SK-MEL-1, SK-MEL- } \\
\text { 28, HEMa-LP, HaCaT }\end{array}$ & Yes & SOX4 & $\begin{array}{l}\text { Wnt/ } \beta \text { - } \\
\text { catenin } \\
\text { and } \\
\text { NF-кB } \\
\text { signaling } \\
\text { pathways }\end{array}$ & clinical stage & $\begin{array}{l}\text { Its overexpression inhibits } \\
\text { proliferation and invasion of } \\
\text { melanoma cells by targeting } \\
\text { SOX } 4 \text { and inactivation of } \\
\text { Wnt/ } \beta \text {-catenin and NF-кB } \\
\text { signaling pathways }\end{array}$ & $(270)$ \\
\hline $\begin{array}{l}\operatorname{miR}-140- \\
3 p\end{array}$ & $\begin{array}{l}25 \text { melanoma tissues and } \\
\text { paired ANTs, } 30 \text { male } \\
\text { BALB/c nude mice (M229, } \\
\text { A375 and M14 cell lines } \\
\text { were injected to mice) }\end{array}$ & $\begin{array}{l}\text { M14, MALME-3M, } \\
\text { M229, WM226, A375, } \\
\text { SKMEL5, LOX IMVI, } \\
\text { HPM }\end{array}$ & Yes & ABHD2 & $\begin{array}{l}\text { JNK and } \\
\text { AKT/ } \\
\text { p70S6K } \\
\text { Signaling } \\
\text { Pathway }\end{array}$ & $\begin{array}{l}\text { Overall } \\
\text { survival }\end{array}$ & $\begin{array}{l}\text { Blocks proliferation, } \\
\text { migration and invasion and } \\
\text { induces apoptosis in } \\
\text { melanoma cell through } \\
\text { targeting ABHD2 }\end{array}$ & $(271)$ \\
\hline$m i R-135 b$ & $\begin{array}{l}27 \text { melanoma tissues and } \\
27 \text { normal skin tissues }\end{array}$ & A375, PEM & Yes & $\mathrm{RBX} 1$ & - & - & $\begin{array}{l}\text { Suppresses proliferation, } \\
\text { migration and invasion of } \\
\text { melanoma cells through } \\
\text { targeting RBX1 }\end{array}$ & $(272)$ \\
\hline
\end{tabular}

changed. In other words, these curves are generated by plotting the true positive rate against the false positive rate at different threshold points. Notably, serum expression levels of several miRNAs have high sensitivity and specificity values for differentiating between melanoma patients and healthy subjects or between metastatic and non-metastatic melanomas. Tables 4, 5 list the miRNAs whose application as diagnostic or prognostic markers has been evaluated using ROC curve analysis, respectively. 
TABLE 3 | Role of melanoma in prediction of prognosis of melanoma (DMFS, distant metastasis free survival; OS, overall survival; DFS, disease-free survival; RFS, relapse-free survival; MSS, melanoma specific survival).

\begin{tabular}{|c|c|c|c|c|c|}
\hline microRNA & Sample number & Kaplan-Meier analysis & Univariate cox regression & Multivariate cox regression & Reference \\
\hline$m i R-10 b$ & $\begin{array}{l}79 \text { primary melanoma tissues and } \\
32 \text { metastases }\end{array}$ & - & $\begin{array}{l}\text { Is a potential prognostic biomarker } \\
\text { associated with metastasis }\end{array}$ & $\begin{array}{l}\text { Can be an independent potential } \\
\text { prognostic factor }\end{array}$ & (33) \\
\hline miR-10b & $\begin{array}{l}78 \text { melanoma tissues and } 30 \text { non- } \\
\text { tumor skin samples }\end{array}$ & $\begin{array}{l}\text { Its high expression is } \\
\text { associated with poor OS in } \\
\text { melanoma patients. }\end{array}$ & - & - & (35) \\
\hline miR-10b & $\begin{array}{l}\text { Blood samples from } 85 \text { melanoma } \\
\text { patients and } 30 \text { healthy volunteers }\end{array}$ & $\begin{array}{l}\text { Its high serum levels is } \\
\text { associated with short DFS } \\
\text { and OS. }\end{array}$ & - & $\begin{array}{l}\text { Its serum level is an independent } \\
\text { prognostic factor for OS and CFS } \\
\text { in melanoma patients. }\end{array}$ & (275) \\
\hline miR-30d & $\begin{array}{l}109 \text { primary melanoma tissues } \\
\text { and } 17 \text { melanoma metastases }\end{array}$ & $\begin{array}{l}\text { Its high expression is } \\
\text { associated with poor OS. }\end{array}$ & - & $\begin{array}{l}\text { Its expression pattern is an } \\
\text { independent prognostic factor for } \\
\text { melanoma mortality. }\end{array}$ & (65) \\
\hline miR-30b & $\begin{array}{l}109 \text { primary melanoma tissues } \\
\text { and } 17 \text { melanoma metastases }\end{array}$ & $\begin{array}{l}\text { Its high expression is } \\
\text { associated with poor OS. }\end{array}$ & - & - & (65) \\
\hline miR-92a & $\begin{array}{l}75 \text { melanoma tissues and paired } \\
\text { ANTs }\end{array}$ & $\begin{array}{l}\text { Its high expression is } \\
\text { associated with poor OS. }\end{array}$ & - & - & (75) \\
\hline miR-596 & $\begin{array}{l}36 \text { melanomas samples and } 22 \\
\text { nevi }\end{array}$ & $\begin{array}{l}\text { Its low expression was } \\
\text { associated with significantly } \\
\text { shorter OS. }\end{array}$ & - & - & (126) \\
\hline $\begin{array}{l}\text { miRNA- } \\
29 c\end{array}$ & $\begin{array}{l}30 \text { malignant melanoma tissues } \\
\text { and } 10 \text { paracancer tissues }\end{array}$ & $\begin{array}{l}\text { Its low expression associated } \\
\text { with poor prognosis. }\end{array}$ & - & - & (128) \\
\hline miR-365 & $\begin{array}{l}40 \text { melanoma tissues and paired } \\
\text { ANTs }\end{array}$ & $\begin{array}{l}\text { Its low expression associated } \\
\text { with shorter OS and RFS. }\end{array}$ & - & - & (97) \\
\hline $\operatorname{miR}-137$ & $\begin{array}{l}30 \text { primary melanoma tissues and } \\
\text { paired ANTs }\end{array}$ & $\begin{array}{l}\text { Its low expression associated } \\
\text { with poor survival. }\end{array}$ & - & $\begin{array}{l}\text { Can be an independent risk factor } \\
\text { of OS }\end{array}$ & (141) \\
\hline $\operatorname{miR}-137$ & $\begin{array}{l}97 \text { melanoma tissues and paired } \\
\text { ANTs }\end{array}$ & $\begin{array}{l}\text { Its low expression is } \\
\text { associated shorter OS in } \\
\text { melanoma patients. }\end{array}$ & - & $\begin{array}{l}\text { Its expression is an independent } \\
\text { prognostic marker of OS in } \\
\text { melanoma patients. }\end{array}$ & (146) \\
\hline $\begin{array}{l}\text { miR-142- } \\
3 p \\
\text { miR-142- } \\
5 p\end{array}$ & 66 stage III FFPE tissues & $\begin{array}{l}\text { Their low expression } \\
\text { associated with poor survival. }\end{array}$ & - & - & (118) \\
\hline miR-21 & $\begin{array}{l}86 \text { primary cutaneous melanomas } \\
\text { tissues, } 10 \text { melanoma metastases, } \\
10 \text { dysplastic nevi samples }\end{array}$ & $\begin{array}{l}\text { Its high expression } \\
\text { associated with shorter 5- } \\
\text { year DFS and shorter 5-year } \\
\text { OS. }\end{array}$ & - & $\begin{array}{l}\text { Its expression pattern can be an } \\
\text { independent prognostic factor for } \\
\text { overall survival in melanoma } \\
\text { patients. }\end{array}$ & (37) \\
\hline $\operatorname{miR}-21$ & $\begin{array}{l}12 \text { FFPE primary melanoma } \\
\text { tissues and } 12 \text { melanocytic nevi }\end{array}$ & $\begin{array}{l}\text { Its high expression is } \\
\text { associated with poor RFS } \\
\text { and OS. }\end{array}$ & - & - & (38) \\
\hline $\operatorname{miR}-181$ & $\begin{array}{l}17 \text { matched melanoma tissues } \\
\text { before and after resistance of } \\
\text { patients to BRAF inhibitors }\end{array}$ & $\begin{array}{l}\text { Its low expression is } \\
\text { correlated with low } \\
\text { progression free survival } \\
\text { (PFS) and OS }\end{array}$ & - & - & (172) \\
\hline $\begin{array}{l}\operatorname{miR}-4633- \\
5 p\end{array}$ & $\begin{array}{l}56 \text { Primary human sinonasal } \\
\text { mucosal melanoma tissues }\end{array}$ & - & $\begin{array}{l}\text { Its expression pattern can be a } \\
\text { prognostic factor in identifying } \\
\text { metastatic sinonasal mucosal } \\
\text { melanoma. }\end{array}$ & $\begin{array}{l}\text { It can be an independent } \\
\text { prognostic factor for metastasis. }\end{array}$ & (175) \\
\hline $\operatorname{miR}-191$ & 32 lymph node metastases & $\begin{array}{l}\text { Its low expression associated } \\
\text { with poor melanoma-specific } \\
\text { survival. }\end{array}$ & - & - & (276) \\
\hline $\operatorname{miR}-193 b$ & 32 lymph node metastases & $\begin{array}{l}\text { Its high associated with poor } \\
\text { melanoma-specific survival. }\end{array}$ & - & - & (276) \\
\hline $\begin{array}{l}\text { hsa-miR- } \\
211-5 p \\
\text { hsa-miR- } \\
\text { 514a-3p } \\
\text { hsa-miR- } \\
\text { 508-3p } \\
\text { hsa-miR- } \\
\text { 509-3-5p } \\
\text { hsa-miR- } \\
\text { 513c-5p }\end{array}$ & $\begin{array}{l}\text { UM dataset of miRNA expression } \\
\text { profiles was obtained from the } \\
\text { UCSC Xena Browser }\end{array}$ & $\begin{array}{l}\text { Their high expression were } \\
\text { associated with poor OS. }\end{array}$ & - & - & (277) \\
\hline
\end{tabular}


TABLE 3 | Continued

\begin{tabular}{|c|c|c|c|c|c|}
\hline microRNA & Sample number & Kaplan-Meier analysis & Univariate cox regression & Multivariate cox regression & Reference \\
\hline \multicolumn{6}{|l|}{ hsa-miR- } \\
\hline \multicolumn{2}{|l|}{ hsa-let-7b- } & $\begin{array}{l}\text { Their low expressions were } \\
\text { associated with poor OS. }\end{array}$ & - & - & $(277)$ \\
\hline \multicolumn{4}{|l|}{ hsa-miR- } & & \\
\hline \multicolumn{6}{|l|}{$452-5 p$} \\
\hline \multicolumn{6}{|l|}{$224-5 p$} \\
\hline \multicolumn{6}{|l|}{ hsa-miR- } \\
\hline \multicolumn{6}{|l|}{592} \\
\hline \multicolumn{6}{|l|}{ hsa-let-7b- } \\
\hline \multicolumn{4}{|l|}{ hsa-miR- } & \\
\hline \multirow{2}{*}{\multicolumn{6}{|c|}{59 metastatic and primary }} \\
\hline & & & & & \\
\hline \multirow{2}{*}{\multicolumn{6}{|c|}{$\begin{array}{l}\text { independent predictor of post- } \\
\text { recurrence survival in metastatic }\end{array}$}} \\
\hline \multirow{2}{*}{\multicolumn{3}{|c|}{ melanoma. }} & & & \\
\hline \multirow{2}{*}{\multicolumn{6}{|c|}{$\begin{array}{l}\text { mir-342-3p } \\
\text { mir-455-3p }\end{array}$}} \\
\hline & & & & & \\
\hline \multicolumn{6}{|l|}{ mir-145 } \\
\hline \multicolumn{6}{|l|}{ mir-155 } \\
\hline \multicolumn{6}{|l|}{ mir-497 } \\
\hline miR-338- & 46 melanoma tissues and 25 & Its high expression is & Its expression correlates to patient & It can be an independent & (48) \\
\hline & normal nevi samples & $\begin{array}{l}\text { associated with decreased } \\
\text { OS. }\end{array}$ & survival & prognostic factor for OS. & \\
\hline \multirow[t]{2}{*}{ miR-203 } & 148 melanoma tissues and paired & Its low expression is & - & It can be an independent & (136) \\
\hline & ANTs & associated with poor OS. & & $\begin{array}{l}\text { prognostic marker for melanoma } \\
\text { patients. }\end{array}$ & \\
\hline \multirow[t]{2}{*}{$\operatorname{miR}-29 c$} & 149 melanoma tissues with AJCC & Its low expression is & Its expression correlates to DFS & Its expression is significantly & (279) \\
\hline & stage I-IV & $\begin{array}{l}\text { associated with poor DFS } \\
\text { and OS in stage III melanoma } \\
\text { patients. }\end{array}$ & and OS & correlated to OS but not DFS. & \\
\hline \multirow[t]{2}{*}{ miR-206 } & serum samples from 60 & Its low serum levels is & - & Its serum level is independent & (185) \\
\hline & $\begin{array}{l}\text { melanoma patients and } 30 \text { healthy } \\
\text { controls }\end{array}$ & $\begin{array}{l}\text { associated with poor DFS } \\
\text { and OS. }\end{array}$ & & prognostic factors for DFS and OS. & \\
\hline \multirow[t]{2}{*}{ miR-18b } & 92 primary melanoma tissues and & Its low expression is & - & - & (199) \\
\hline & 48 benign nevi samples & associated with shorter OS. & & & \\
\hline $\operatorname{miR}-15 b$ & 128 FFPE tissues of primary & Its high expression is & - & Its expression pattern can be an & (50) \\
\hline & $\begin{array}{l}\text { melanomas and } 11 \text { melanocytic } \\
\text { nevi samples }\end{array}$ & associated with RFS and OS. & & $\begin{array}{l}\text { independent prognostic factor for } \\
\text { DFS and OS. }\end{array}$ & \\
\hline miR-183 & 30 melanoma tissues and 14 & Its low expression is & - & - & (214) \\
\hline & normal skin samples & associated with poor OS. & & & \\
\hline miR-23a & Serum samples from 192 & Its low serum level is & Its serum level is predictor of & Its serum level is an independent & (106) \\
\hline & $\begin{array}{l}\text { melanoma patients and } 51 \\
\text { matched cancer-free controls }\end{array}$ & associated with poor OS. & patients OS. & prognostic biomarker for OS. & \\
\hline miR-23b & 114 primary melanoma tissues & Its low expression is & - & - & $(107)$ \\
\hline & and ANTs & associated with short 3-year & & & \\
\hline & & $\begin{array}{l}\text { survival in melanoma } \\
\text { patients. }\end{array}$ & & & \\
\hline miR-216a- & 86 uveal melanoma tissues & Its low expression is & - & - & (115) \\
\hline & & $\begin{array}{l}\text { associated with poor DFS } \\
\text { and OS. }\end{array}$ & & & \\
\hline miR-221 & Serum samples from 72 & Its high expression is & - & Its expression can be an & (55) \\
\hline & $\begin{array}{l}\text { cutaneous malignant melanoma } \\
\text { and } 54 \text { healthy controls }\end{array}$ & $\begin{array}{l}\text { associated with poor RFS } \\
\text { and OS. }\end{array}$ & & $\begin{array}{l}\text { independent predictor of DFS and } \\
\text { OS }\end{array}$ & \\
\hline miR-205 & 319 melanoma tissue samples & Its low expression is & Its expression can be a predictor of & Its expression pattern can be an & (280) \\
\hline & & $\begin{array}{l}\text { associated with short MMS in } \\
\text { melanoma patients. }\end{array}$ & MMS & $\begin{array}{l}\text { independent prognostic marker for } \\
\text { MMS }\end{array}$ & \\
\hline miR-205 & 65 primary melanoma tissues and & Its low expression is & - & Its expression pattern can be an & (125) \\
\hline & 67 melanoma metastases & associated with shorter & & independent prognostic factor of & \\
\hline & & DMFS and MSS. & & MMS & \\
\hline
\end{tabular}


TABLE 3 | Continued

\begin{tabular}{|c|c|c|c|c|c|}
\hline microRNA & Sample number & Kaplan-Meier analysis & Univariate cox regression & Multivariate cox regression & Reference \\
\hline miR-200c & $\begin{array}{l}65 \text { primary melanoma tissues and } \\
67 \text { melanoma metastases }\end{array}$ & $\begin{array}{l}\text { Its low expression is } \\
\text { associated with shorter } \\
\text { DMFS and MSS. }\end{array}$ & - & $\begin{array}{l}\text { Its expression pattern can be an } \\
\text { independent prognostic factor of } \\
\text { survival }\end{array}$ & $(125)$ \\
\hline miR-200a & $\begin{array}{l}46 \text { melanoma tissues and paired } \\
\text { ANTs }\end{array}$ & $\begin{array}{l}\text { Its low expression is } \\
\text { associated with poor OS. }\end{array}$ & - & - & $(195)$ \\
\hline $\operatorname{miR}-125$ & $\begin{array}{l}65 \text { primary melanoma tissues and } \\
67 \text { melanoma metastases }\end{array}$ & $\begin{array}{l}\text { Its low expression is } \\
\text { associated with shorter } \\
\text { DMFS and MSS. }\end{array}$ & - & $\begin{array}{l}\text { Its expression pattern can be an } \\
\text { independent prognostic factor of } \\
\text { survival }\end{array}$ & $(125)$ \\
\hline $\operatorname{miR}-150$ & $\begin{array}{l}51 \text { melanoma tissues and paired } \\
\text { ANTs }\end{array}$ & $\begin{array}{l}\text { Its low expression is } \\
\text { associated with short RFS } \\
\text { and OS. }\end{array}$ & 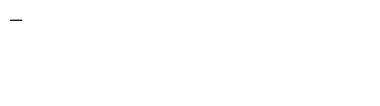 & - & $(117)$ \\
\hline let-7b & $\begin{array}{l}106 \text { mucosal melanoma tissues, } \\
\text { mucosal nevi samples }\end{array}$ & $\begin{array}{l}\text { Its low expression is } \\
\text { associated with poor DFS. }\end{array}$ & $\begin{array}{l}\text { Its expression level correlates with } \\
\text { DFS in melanoma patients }\end{array}$ & $\begin{array}{l}\text { Its expression pattern is an } \\
\text { independent prognostic marker for } \\
\text { DFS }\end{array}$ & $(211)$ \\
\hline let-7c & $\begin{array}{l}106 \text { mucosal melanoma tissues, } \\
\text { mucosal nevi samples }\end{array}$ & $\begin{array}{l}\text { Its low expression is } \\
\text { associated with poor DFS. }\end{array}$ & $\begin{array}{l}\text { Its expression level correlates with } \\
\text { DFS in melanoma patients }\end{array}$ & $\begin{array}{l}\text { Its expression pattern is an } \\
\text { independent prognostic marker for } \\
\text { DFS }\end{array}$ & $(211)$ \\
\hline miR-126 & $\begin{array}{l}108 \text { primary cutaneous melanoma } \\
\text { tissues, } 18 \text { melanoma metastases } \\
\text { and } 16 \text { dysplastic nevi samples }\end{array}$ & $\begin{array}{l}\text { Its low expression is } \\
\text { associated with poor OS in } \\
\text { melanoma patients }\end{array}$ & - & $\begin{array}{l}\text { Can be an independent prognostic } \\
\text { factor for overall survival }\end{array}$ & $(251)$ \\
\hline $\operatorname{miR}-127$ & $\begin{array}{l}40 \text { melanoma tissues and paired } \\
\text { ANTs }\end{array}$ & $\begin{array}{l}\text { Its low expression is } \\
\text { associated with short OS }\end{array}$ & - & - & $(256)$ \\
\hline $\operatorname{miR}-22$ & $\begin{array}{l}48 \text { melanoma tissues and paired } \\
\text { ANTs }\end{array}$ & $\begin{array}{l}\text { Its low expression is } \\
\text { associated with shorter OS }\end{array}$ & - & - & $(257)$ \\
\hline $\operatorname{miR}-610$ & 105 melanoma tissues and ANTs & $\begin{array}{l}\text { Its low expression is } \\
\text { associated with short } 5 \text {-year } \\
\text { survival }\end{array}$ & - & - & $(260)$ \\
\hline $\operatorname{miR}-431$ & $\begin{array}{l}113 \text { melanoma tissues and paired } \\
\text { ANTs }\end{array}$ & $\begin{array}{l}\text { Its low expression is } \\
\text { associated with poor OS in } \\
\text { melanoma patients }\end{array}$ & $\begin{array}{l}\text { Can be a potential prognostic } \\
\text { marker for melanoma patients }\end{array}$ & $\begin{array}{l}\text { Can be an independent prognostic } \\
\text { factor for melanoma patients }\end{array}$ & $(267)$ \\
\hline $\begin{array}{l}m i R-140- \\
3 p\end{array}$ & $\begin{array}{l}25 \text { melanoma tissues and paired } \\
\text { ANTs }\end{array}$ & $\begin{array}{l}\text { Its low is associated with } \\
\text { poor OS }\end{array}$ & $\begin{array}{l}\text { Its expression pattern correlates } \\
\text { with OS in melanoma patients }\end{array}$ & $\begin{array}{l}\text { Its expression pattern is an } \\
\text { independent prognostic factor for } \\
\text { OS in melanoma patients }\end{array}$ & $(271)$ \\
\hline miR-125b & $\begin{array}{l}29 \text { FFPE melanoma specimens } \\
\text { and } 16 \text { intradermal nevus } \\
\text { specimens }\end{array}$ & $\begin{array}{l}\text { Its low expression is } \\
\text { associated with short OS }\end{array}$ & - & $\begin{array}{l}\text { Its expression level can be an } \\
\text { independent prognostic marker for } \\
\text { OS }\end{array}$ & $(281)$ \\
\hline
\end{tabular}

\section{IMPLICATIONS OF MIRNAS IN THE TREATMENT OF MELANOMA}

miRNAs are implicated in the therapeutic effects of several anticancer agents. For instance, Genistein, the isoflavone extracted from soybean, has been shown to suppress proliferation of human uveal melanoma cells possibly through modulating expression of miR-27a and its target gene ZBTB10 (291).

miRNAs are also involved in conferring resistance to immunotherapeutic modalities. For instance, expression of miR-222 has been shown to be higher in melanoma samples obtained from patients who did not respond to ipilimumab compared with those benefitting from this option (292). Mechanistically, the ADAR1/miR-222/ICAM1 axis has been reported to be involved in this process (292). Other miRNAs such as miR-488-3p, miR-195 and miR-211 participate in the regulation of response to the chemotherapeutic agent cisplatin $(130,162,163)$

Application of miRNAs in the therapeutic settings is limited by target specificity issues (293). However, some miRNAs are currently being tested in some diseases. Among these therapeutic modalities are miR-122/miravirsen and miR-92/MRG 110 which have been manufactured by Roche/Santaris and Regulus Therapeutics, respectively (293).

\section{ASSOCIATION BETWEEN POLYMORPHISMS WITHIN MIRNAS AND RISK OF MELANOMA}

Theoretically, polymorphisms with miRNA coding genes can alter their expression or function. Although such polymorphisms are predicted to influence the risk of different cancers such as melanoma, this field has not been vastly explored. Few studies have assessed association between a certain polymorphism within miR-146a namely the rs2910164 G/C and melanoma risk. In spite of the proposed role for allele $\mathrm{C}$ of this polymorphism in conferring risk of melanoma $(294,295)$, cell line studies have shown that $\mathrm{G}$ allele confers high proliferative capacity to melanoma cells (296). Table 6 summarizes the results of these studies. 
TABLE 4 | Application of miRNAs as diagnostic tools in melanoma.

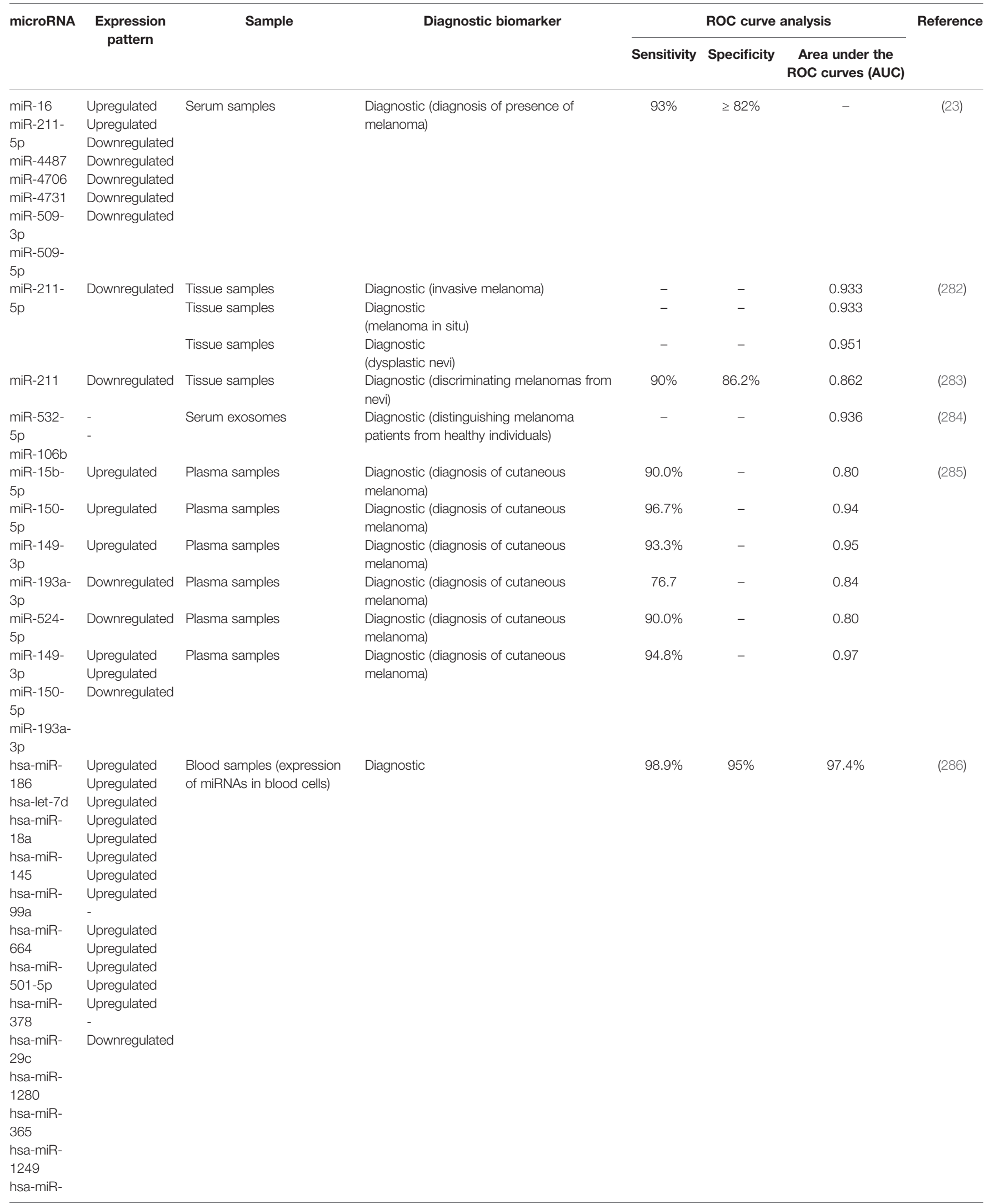


TABLE 4 | Continued

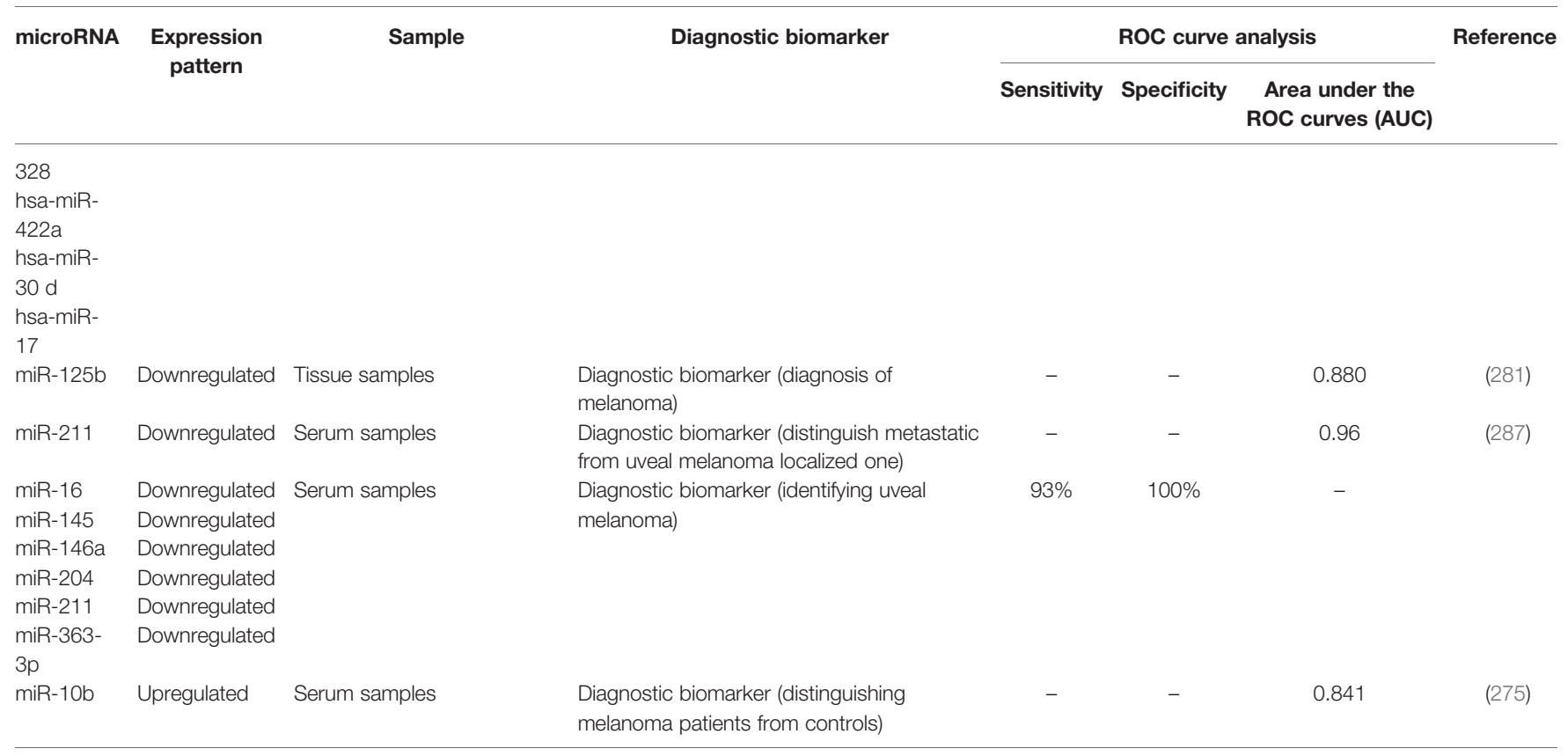

\section{DISCUSSION}

Dysregulation of miRNAs in melanoma samples and cell line have been reported by several studies. The functional consequences of such dysregulation on cell behavior have also been appraised. However, the underlying mechanism of such dysregulation is not clarified completely. Copy number variations in miRNA-coding genes or genes associated with the biogenesis or function of miRNAs may be responsible for the observed dysregulation of miRNAs in melanoma and other types of cancers (10). Moreover, the role of epigenetic factors in this process should not be ignored. For instance, CpG methylation of the miR-34a promoter has been suggested as an underlying mechanism for down-regulation of this miRNA in primary melanoma samples and melanoma cell lines (297). Another possible mediators of miRNA dysregulation in the melanoma are melanoma-inducing transcription factors such as MITF whose role in the expression of a number of miRNAs has been verified (298). As several miRNAs are implicated in the modulation of skin response to ultraviolet radiation (299), this environmental carcinogen might also affect expression of miRNAs which are involved in the melanomagenesis.

Mechanistically, several melanoma-associated miRNAs function upstream or downstream of known oncogenes in melanoma. For instance, miR-137 and miR-182 are among miRNAs that target MITF oncogene (54, 300). Moreover, expressions of several miRNAs such as a number of let-7 family members, miR-221/222, miR-17-92 and miR-106-363 clusters, miR-29, miR-146a, miR-148b, and miR-125b have been shown to be modulated by MITF (298). Moreover, several miRNAs such as miR-7, miR-23a and miR-596 have functional interactions with MAPK/ERK and PI3K/PTEN/Akt signaling pathways in the context of melanoma. A number of
miRNAs such as miR-378, miR-10b, miR-25, miR-485-5p, miR708, miR-136, miR-488-5p, miR-29a, miR-22 and miR-140-5p have interactions with $\mathrm{Wnt} / \beta$-catenin pathway. Finally, miR-21, miR-7-5p, miR-23b, miR-145-5p, miR-9, miR-29a, miR-377 and miR-140-5p interacts with NF- $\kappa B$ signaling in the context of melanoma development. Thus, a number of miRNAs provide functional links between cancer-related pathways in this context.

miRNAs have functions both in the paternal cell in which they are produced as well as in the adjoining cells. These transcripts can modulate characteristics of adjacent melanoma cells or directly affect tumor niche by modifying extracellular matrix and function of resident cells in this environment including fibroblasts and endothelial or immune cells. This activity of miRNAs potentiates them as contributors of melanoma metastatic potential through affecting intravasation of cancer cells into vessels, viability of tumor cells in the circulation, their leakage in the target tissues, and establishment of the pre-metastatic milieu in remote organs (301).

Several miRNAs have been shown to differentiate melanoma patients from healthy subjects or distinguish between metastatic and non-metastatic melanoma patients. The prognostic assays founded on miRNAs signature can enhance the efficacy of conventional staging systems in predicting patients' prognosis and their management in the clinical settings in the terms of choosing adjuvant therapies or clinical trial enrolment. Therefore, these miRNAs are potential biomarkers for this kind of skin cancer.

Numerous miRNAs have been dysregulated in tumor samples or peripheral blood of patients with melanoma. Such dysregulation can be used as biomarker for early detection of melanoma or follow-up of patients after initial treatments to uncover any possible tumor recurrence. Blood-based biomarkers are expected to substitute invasive methods of cancer diagnosis 
TABLE 5 | Prognostic role of miRNAs in melanoma as identified by ROC curve analysis.

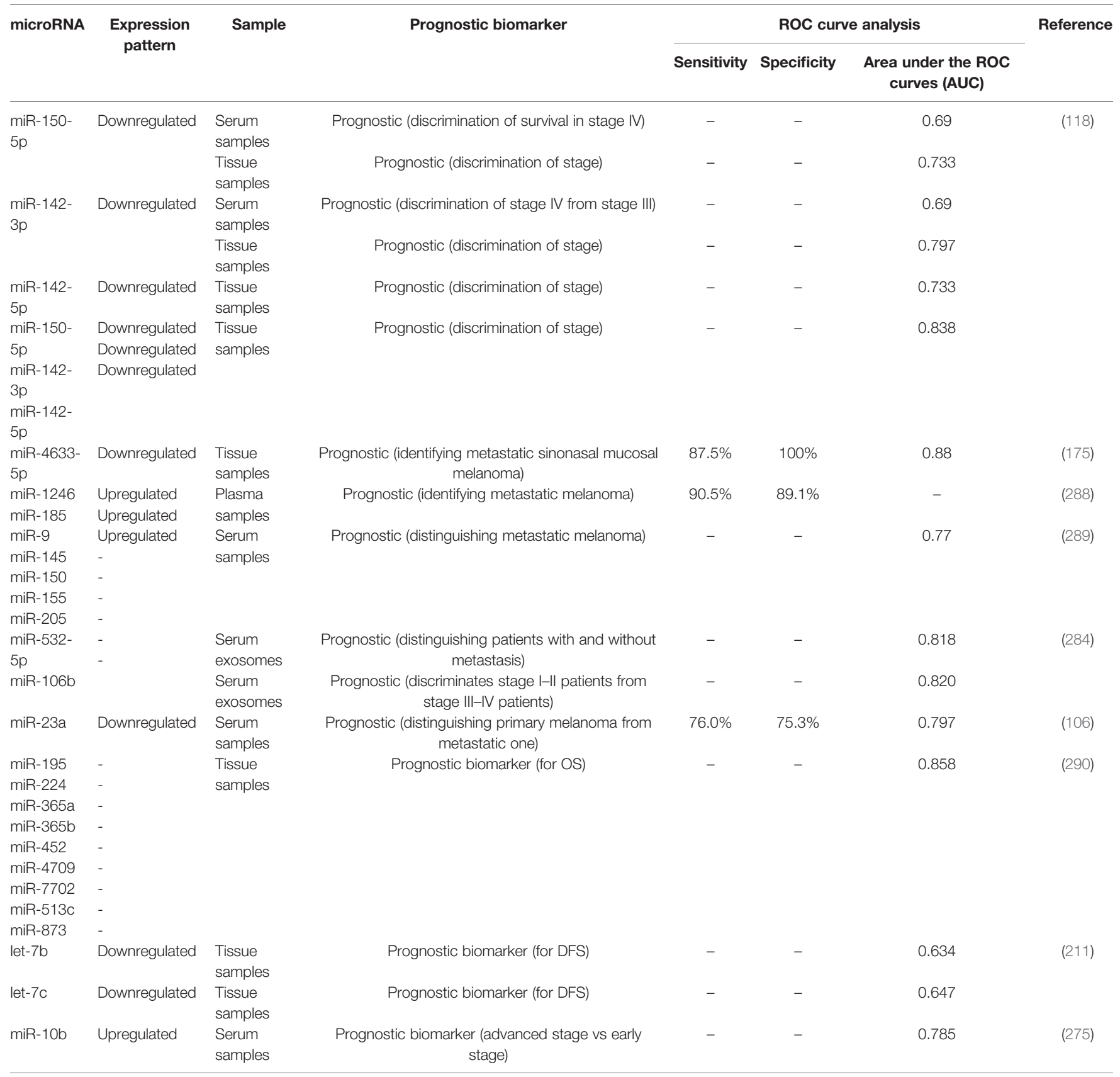

in future. Based on the heterogeneous pattern of miRNAs expression in tumor samples and the varied expressions among affected individuals, multi-miRNA panels are more promising in the diagnostic approaches compared with individual miRNAs.

Finally, miRNAs might be implicated in the anti-cancer effects of a number of therapeutic agents including both chemical and herbal medicines. Evidence for supporting this idea has come from several studies including a study which revealed the role of miR-27a in mediating the anti-proliferative effects of Genistein in human uveal melanoma cells (291). Moreover, the observed upregulation of miR-222 in melanoma samples obtained from patients who did not respond to ipilimumab compared with those benefitting from this option (292) implies its contribution in resistance to this agent. Therefore, miRNAs are promising targets for modulation of response of melanoma cells to a wide range of therapeutic options.

\section{PERSPECTIVES AND FUTURE DIRECTIONS}

Assessment of expression pattern of miRNAs in cohorts of melanoma patients from different ethnicities and uncovering 
TABLE 6 | Summary of studies which assessed association between miRNA polymorphisms and risk of melanoma.

\begin{tabular}{|c|c|c|c|c|c|c|}
\hline microRNA & SNP & $\begin{array}{l}\text { Genotyping } \\
\text { method }\end{array}$ & Samples & Association with melanoma & Functional experiments & Reference \\
\hline miR-146a & rs2910164G>C & - & $\begin{array}{l}\text { Blood samples from } 224 \\
\text { patients and } 264 \text { healthy } \\
\text { controls }\end{array}$ & $\begin{array}{l}\text { Allele } \mathrm{C} \text { was associated with risk } \\
\text { of melanoma in males and has } \\
\text { allelic dosage effect (CC } \\
\text { homozygotes has greater risk) }\end{array}$ & - & (294) \\
\hline $\begin{array}{l}\text { miR-146a and } \\
\text { RNASEL } \\
\text { polymorphisms } \\
\text { interaction }\end{array}$ & $\begin{array}{l}\text { rs2910164 G/C } \\
\text { (in miR-146a) } \\
\text { rs486907 A/G (in } \\
\text { RNASEL) }\end{array}$ & PCR-RFLP & $\begin{array}{l}\text { Blood samples from } 304 \\
\text { sporadic melanoma } \\
\text { patients and } 314 \text { control } \\
\text { individuals }\end{array}$ & $\begin{array}{l}\text { Men carrying allelic combination } \\
\text { miR-146a rs2910164 C and } \\
\text { RNASEL rs486907 A have } \\
\text { highest risk of melanoma }\end{array}$ & ( & (295) \\
\hline miR-146a & rs2910164 G/C & PCR-RFLP & $\begin{array}{l}\text { Skin samples from } 50 \\
\text { melanoma patients and } \\
107 \text { controls, } 8 \text { blood } \\
\text { samples from patients }\end{array}$ & $\begin{array}{l}\text { GC genotype was significantly } \\
\text { increased in the patients } \\
\text { compared with the controls }\end{array}$ & $\begin{array}{l}\text { G allele confers high proliferative } \\
\text { capacity to melanoma cell lines and } \\
\text { GC cell lines have more invasive and } \\
\text { migratory ability than CC cell lines }\end{array}$ & (296) \\
\hline
\end{tabular}

their association with genetic polymorphisms would facilitate design of prognostic/diagnostic panels. The relationship between aberrant miRNA profile and response to therapeutic regimens should be unraveled. Such kinds of approaches pave the way for design of personalized methods of treatment of melanoma. Therapeutic targeting of miRNAs can influence melanoma course and enhance sensitivity to both conventional therapies and immunotherapeutic approaches. Yet, safety and bioavailability issues remained to be

\section{REFERENCES}

1. Linos E, Swetter SM, Cockburn MG, Colditz GA, Clarke CA. Increasing Burden of Melanoma in the United States. J Invest Dermatol (2009) 129 (7):1666-74. doi: 10.1038/jid.2008.423

2. Noone A, Howlader N, Krapcho M, Miller D, Brest A, Yu M, et al. SEER Cancer Statistics Review, 1975-2015 Vol. 4. Bethesda, MD: National Cancer Institute (2018).

3. Erdei E, Torres SM. A New Understanding in the Epidemiology of Melanoma. Expert Rev Anticancer Ther (2010) 10(11):1811-23. doi: 10.1586/era.10.170

4. Liu Y, Sheikh MS. Melanoma: Molecular Pathogenesis and Therapeutic Management. Mol Cell Pharmacol (2014) 6(3):228.

5. Safa A, Gholipour M, Dinger ME, Taheri M, Ghafouri-Fard S. The Critical Roles of LncRNAs in the Pathogenesis of Melanoma. Exp Mol Pathol (2020) 117:104558. doi: 10.1016/j.yexmp.2020.104558

6. Gellrich FF, Schmitz M, Beissert S, Meier F. Anti-PD-1 and Novel Combinations in the Treatment of Melanoma-an Update. J Clin Med (2020) 9(1):223. doi: 10.3390/jcm9010223

7. Howell PM, Li X, Riker AI, Xi Y. MicroRNA in Melanoma. Ochsner J (2010) 10(2):83-92.

8. O’Brien J, Hayder H, Zayed Y, Peng C. Overview of MicroRNA Biogenesis, Mechanisms of Actions, and Circulation. Front Endocrinol (2018) 9:402. doi: 10.3389/fendo.2018.00402

9. Vasudevan S, Steitz JA. AU-rich-element-mediated Upregulation of Translation by FXR1 and Argonaute 2. Cell (2007) 128(6):1105-18. doi: 10.1016/j.cell.2007.01.038

10. Zhang L, Huang J, Yang N, Greshock J, Megraw MS, Giannakakis A, et al. MicroRNAs Exhibit High Frequency Genomic Alterations in Human Cancer. Proc Natl Acad Sci (2006) 103(24):9136-41. doi: 10.1073/pnas.0508889103

11. Aksenenko M, Palkina N, Komina A, Tashireva L, Ruksha T. Differences in MicroRNA Expression Between Melanoma and Healthy Adjacent Skin. BMC Dermatol (2019) 19(1):1-9. doi: 10.1186/s12895-018-0081-1

12. Ren J-W, Li Z-J, Tu C. MiR-135 Post-Transcriptionally Regulates FOXO1 Expression and Promotes Cell Proliferation in Human Malignant Melanoma Cells. Int J Clin Exp Pathol (2015) 8(6):6356. solved before implementation of these techniques in the clinical settings.

\section{AUTHOR CONTRIBUTIONS}

SG-F and MT wrote the draft and revised it. MG collected the tables and designed it. All authors contributed to the article and approved the submitted version.

13. Ratnayke WS, Apostolatos CA, Breedy S, Apostolatos AH, Acevedo-Duncan M. FOXO1 Regulates Oncogenic PKC-1 Expression in Melanoma Inversely to c-Jun in an Autocrine Manner Via IL-17E and ICAM-1 Activation. World Acad Sci J (2019) 1(1):25-38. doi: 10.3892/wasj.2018.1

14. Dar AA, Majid S, de Semir D, Nosrati M, Bezrookove V, Kashani-Sabet M. MiRNA-205 Suppresses Melanoma Cell Proliferation and Induces Senescence Via Regulation of E2F1 Protein. J Biol Chem (2011) 286 (19):16606-14. doi: 10.1074/jbc.M111.227611

15. Mueller DW, Rehli M, Bosserhoff AK. MiRNA Expression Profiling in Melanocytes and Melanoma Cell Lines Reveals MiRNAs Associated With Formation and Progression of Malignant Melanoma. J Invest Dermatol (2009) 129(7):1740-51. doi: 10.1038/jid.2008.452

16. Levati L, Alvino E, Pagani E, Arcelli D, Caporaso P, Bondanza S, et al. Altered Expression of Selected MicroRNAs in Melanoma: Antiproliferative and Proapoptotic Activity of Mirna-155. Int J Oncol (2009) 35(2):393-400. doi: 10.3892/ijo_00000352

17. Felicetti F, Errico MC, Segnalini P, Mattia G, Carè A. MicroRNA-221 and222 Pathway Controls Melanoma Progression. Expert Rev Anticancer Ther (2008) 8(11):1759-65. doi: 10.1586/14737140.8.11.1759

18. Igoucheva O, Alexeev V. MicroRNA-dependent Regulation of cKit in Cutaneous Melanoma. Biochem Biophys Res Commun (2009) 379(3):7904. doi: 10.1016/j.bbrc.2008.12.152

19. Zhang Z, Sun H, Dai H, Walsh R, Imakura M, Schelter J, et al. MicroRNA miR-210 Modulates Cellular Response to Hypoxia Through the MYC Antagonist MNT. Cell Cycle (2009) 8(17):2756-68. doi: 10.4161/cc.8.17.9387

20. Vitiello M, Tuccoli A, D’Aurizio R, Sarti S, Giannecchini L, Lubrano S, et al. Context-Dependent miR-204 and miR-211 Affect the Biological Properties of Amelanotic and Melanotic Melanoma Cells. Oncotarget (2017) 8 (15):25395. doi: 10.18632/oncotarget.15915

21. Sahoo A, Sahoo SK, Joshi P, Lee B, Perera RJ. MicroRNA-211 Loss Promotes Metabolic Vulnerability and BRAF Inhibitor Sensitivity in Melanoma. J Invest Dermatol (2019) 139(1):167-76. doi: 10.1016/j.jid.2018.06.189

22. Díaz-Martínez M, Benito-Jardón L, Alonso L, Koetz-Ploch L, Hernando E, Teixidó J. miR-204-5p and miR-211-5p Contribute to BRAF Inhibitor Resistance in Melanoma. Cancer Res (2018) 78(4):1017-30. doi: 10.1158/ 0008-5472.CAN-17-1318 
23. Stark MS, Klein K, Weide B, Haydu LE, Pflugfelder A, Tang YH, et al. The Prognostic and Predictive Value of Melanoma-Related MicroRNAs Using Tissue and Serum: A MicroRNA Expression Analysis. EBioMedicine (2015) 2(7):671-80. doi: 10.1016/j.ebiom.2015.05.011

24. Sun M, Ma X, Tu C, Wang X, Qu J, Wang S, et al. MicroRNA-378 Regulates Epithelial-Mesenchymal Transition and Metastasis of Melanoma by Inhibiting FOXN3 Expression Through the Wnt/ $\beta$-Catenin Pathway. Cell Biol Int (2019) 43(10):1113-24. doi: 10.1002/cbin.11027

25. Tupone MG, D’Aguanno S, Di Martile M, Valentini E, Desideri M, Trisciuoglio D, et al. MicroRNA-378a-5p is a Novel Positive Regulator of Melanoma Progression. Oncogenesis (2020) 9(2):1-13. doi: 10.1038/s41389020-0203-6

26. Pencheva N, Tran H, Buss C, Huh D, Drobnjak M, Busam K, et al. Convergent Multi-MiRNA Targeting of Apoe Drives LRP1/LRP8dependent Melanoma Metastasis and Angiogenesis. Cell (2012) 151 (5):1068-82. doi: 10.1016/j.cell.2012.10.028

27. Lin N, Zhou Y, Lian X, Tu Y. Expression of MicroRNA-106b and Its Clinical Significance in Cutaneous Melanoma. Genet Mol Res (2015) 14(4):16379-85. doi: 10.4238/2015.December.9.6

28. Wang J, Li H, Zhang J, Zhang C, Hou X. Suppression of Connexin 43 Expression by miR-106a Promotes Melanoma Cell Proliferation. Eur Rev Med Pharmacol Sci (2019) 23(3):965-71. doi: 10.26355/ eurrev_201902_16983

29. Mastroianni J, Stickel N, Andrlova H, Hanke K, Melchinger W, Duquesne S, et al. miR-146a Controls Immune Response in the Melanoma Microenvironment. Cancer Res (2019) 79(1):183-95. doi: 10.1158/00085472.CAN-18-1397

30. Raimo M, Orso F, Grassi E, Cimino D, Penna E, De Pittà C, et al. miR-146a Exerts Differential Effects on Melanoma Growth and Metastatization. Mol Cancer Res (2016) 14(6):548-62. doi: 10.1158/1541-7786.MCR-15-0425-T

31. Forloni M, Dogra SK, Dong Y, Conte D, Ou J, Zhu LJ, et al. miR-146a Promotes the Initiation and Progression of Melanoma by Activating Notch Signaling. Elife (2014) 3:e01460. doi: 10.7554/eLife.01460

32. Pu W, Shang Y, Shao Q, Yuan X. miR-146a Promotes Cell Migration and Invasion in Melanoma by Directly Targeting SMAD4. Oncol Lett (2018) 15 (5):7111-7. doi: 10.3892/ol.2018.8172

33. Saldanha G, Elshaw S, Sachs P, Alharbi H, Shah P, Jothi A, et al. MicroRNA$10 \mathrm{~b}$ is a Prognostic Biomarker for Melanoma. Modern Pathol (2016) 29 (2):112-21. doi: 10.1038/modpathol.2015.149

34. Datar I, Kalpana G, Choi J, Basuroy T, Trumbly R, Chaitanya Arudra SK, et al. Critical Role of miR-10b in B-RafV600E Dependent Anchorage Independent Growth and Invasion of Melanoma Cells. PloS One (2019) 14(4):e0204387. doi: 10.1371/journal.pone.0204387

35. Wang S, Wu Y, Xu Y, Tang X. miR-10b Promoted Melanoma Progression Through Wnt/ $\beta$-Catenin Pathway by Repressing ITCH Expression. Gene (2019) 710:39-47. doi: 10.1016/j.gene.2019.05.043

36. Jiao J, Fan Y, Zhang Y. Expression and Clinicopathological Significance of MicroRNA-21 and Programmed Cell Death 4 in Malignant Melanoma. J Int Med Res (2015) 43(5):672-8. doi: 10.1177/0300060515583707

37. Jiang L, Lv X, Li J, Li J, Li X, Li W, et al. The Status of MicroRNA-21 Expression and Its Clinical Significance in Human Cutaneous Malignant Melanoma. Acta Histochem (2012) 114(6):582-8. doi: 10.1016/ j.acthis.2011.11.001

38. Satzger I, Mattern A, Kuettler U, Weinspach D, Niebuhr M, Kapp A, et al. Micro RNA-21 is Upregulated in Malignant Melanoma and Influences Apoptosis of Melanocytic Cells. Exp Dermatol (2012) 21(7):509-14. doi: 10.1111/j.1600-0625.2012.01510.x

39. Del Campo SEM, Latchana N, Levine KM, Grignol VP, Fairchild ET, JaimeRamirez AC, et al. MiR-21 Enhances Melanoma Invasiveness Via Inhibition of Tissue Inhibitor of Metalloproteinases 3 Expression: in Vivo Effects of MiR-21 Inhibitor. PloS One (2015) 10(1):e0115919. doi: 10.1371/ journal.pone.0115919

40. Mao XH, Chen M, Wang Y, Cui PG, Liu SB, Xu ZY. MicroRNA-21 Regulates the ERK/NF-kb Signaling Pathway to Affect the Proliferation, Migration, and Apoptosis of Human Melanoma A375 Cells by Targeting SPRY1, PDCD4, and PTEN. Mol Carcinogen (2017) 56(3):886-94. doi: 10.1002/ mc. 22542
41. Wang Y-C, Yang X, Wei W-B, Xu X-L. Role of MicroRNA-21 in Uveal Melanoma Cell Invasion and Metastasis by Regulating p53 and Its Downstream Protein. Int J Ophthalmol (2018) 11(8):1258. doi: 10.18240/ ijo.2018.08.03

42. Yang Z, Liao B, Xiang X, Ke S. miR-21-5p Promotes Cell Proliferation and G1/s Transition in Melanoma by Targeting CDKN2C. FEBS Open Bio (2020) 10(5):752-60. doi: 10.1002/2211-5463.12819

43. Xia Z, Yang C, Yang X, Wu S, Feng Z, Qu L, et al. MiR-652 Promotes Proliferation and Migration of Uveal Melanoma Cells by Targeting HOXA9. Med Sci Monit (2019) 25:8722. doi: 10.12659/MSM.917099

44. Ling J, Lu P, Zhang Y, Jiang S, Zhang Z. miR-367 Promotes Uveal Melanoma Cell Proliferation and Migration by Regulating PTEN. Genet Mol Res (2017) 16(3). doi: $10.4238 / \mathrm{gmr} 16039067$

45. Komina A, Palkina N, Aksenenko M, Tsyrenzhapova S, Ruksha T. Antiproliferative and Pro-Apoptotic Effects of MiR-4286 Inhibition in Melanoma Cells. PloS One (2016) 11(12):e0168229. doi: 10.1371/ journal.pone.0168229

46. Long J, Luo J, Yin X. miR-367 Enhances the Proliferation and Invasion of Cutaneous Malignant Melanoma by Regulating Phosphatase and Tensin Homolog Expression. Mol Med Rep (2018) 17(5):6526-32. doi: 10.3892/ mmr.2018.8663

47. Bhattacharya A, Schmitz U, Raatz Y, Schönherr M, Kottek T, Schauer M, et al. miR-638 Promotes Melanoma Metastasis and Protects Melanoma Cells From Apoptosis and Autophagy. Oncotarget (2015) 6(5):2966. doi: 10.18632/oncotarget.3070

48. Long J, Luo J, Yin X. MiR-338-5p Promotes the Growth and Metastasis of Malignant Melanoma Cells Via Targeting CD82. Biomed Pharmacother (2018) 102:1195-202. doi: 10.1016/j.biopha.2018.03.075

49. Hao T, Li C, Ding X, Xing X. MicroRNA-363-3p/p21 (Cip1/Waf1) Axis is Regulated by HIF-2 $\alpha$ in Mediating Stemness of Melanoma Cells. Neoplasma (2019) 66(3):427-36. doi: 10.4149/neo_2018_180828N655

50. Satzger I, Mattern A, Kuettler U, Weinspach D, Voelker B, Kapp A, et al. MicroRNA-15b Represents an Independent Prognostic Parameter and is Correlated With Tumor Cell Proliferation and Apoptosis in Malignant Melanoma. Int J Cancer (2010) 126(11):2553-62. doi: 10.1002/ijc.24960

51. Sun L, Wang Q, Gao X, Shi D, Mi S, Han Q. MicroRNA-454 Functions as an Oncogene by Regulating PTEN in Uveal Melanoma. FEBS Lett (2015) 589 (19):2791-6. doi: 10.1016/j.febslet.2015.08.007

52. Penna E, Orso F, Cimino D, Tenaglia E, Lembo A, Quaglino E, et al. MicroRNA-214 Contributes to Melanoma Tumour Progression Through Suppression of TFAP2C. EMBO J (2011) 30(10):1990-2007. doi: 10.1038/ emboj.2011.102

53. Li J, Zhao R, Fang R, Wang J. miR-122-5p Inhibits the Proliferation of Melanoma Cells by Targeting NOP14. J South Med Univ (2018) 38 (11):1360-5. doi: 10.12122/j.issn.1673-4254.2018.11.14

54. Segura MF, Hanniford D, Menendez S, Reavie L, Zou X, Alvarez-Diaz S, et al. Aberrant miR-182 Expression Promotes Melanoma Metastasis by Repressing FOXO3 and Microphthalmia-Associated Transcription Factor. Proc Natl Acad Sci (2009) 106(6):1814-9. doi: 10.1073/pnas.0808263106

55. Li P, He Q-Y, Luo C-Q, Qian L-Y. Circulating miR-221 Expression Level and Prognosis of Cutaneous Malignant Melanoma. Med Sci Monit (2014) 20:2472. doi: 10.12659/MSM.891327

56. Zhang K, Guo L. MiR-767 Promoted Cell Proliferation in Human Melanoma by Suppressing CYLD Expression. Gene (2018) 641:272-8. doi: 10.1016/j.gene.2017.10.055

57. Hu Y, Wang Q, Zhu X-H. MiR-135b is a Novel Oncogenic Factor in Cutaneous Melanoma by Targeting LATS2. Melanoma Res (2019) 29 (2):119-25. doi: 10.1097/CMR.0000000000000524

58. Jiang Q-Q, Liu W-B. miR-25 Promotes Melanoma Progression by Regulating RNA Binding Motif Protein 47. Médecine/Sciences (2018) 34:59-65. doi: 10.1051/medsci/201834f111

59. Huo J, Zhang Y, Li R, Wang Y, Wu J, Zhang D. Upregulated MicroRNA-25 Mediates the Migration of Melanoma Cells by Targeting DKK3 Through the WNT/ $\beta$-Catenin Pathway. Int J Mol Sci (2016) 17(11):1124. doi: 10.3390/ ijms 17111124

60. Koetz-Ploch L, Hanniford D, Dolgalev I, Sokolova E, Zhong J, DíazMartínez M, et al. Micro RNA-125a Promotes Resistance to BRAF 
Inhibitors Through Suppression of the Intrinsic Apoptotic Pathway. Pigment Cell Melanoma Res (2017) 30(3):328-38. doi: 10.1111/pcmr.12578

61. Chen X-E, Chen P, Chen S-S, Ma T, Shi G, Zhou Y, et al. miR-106b-5p Promotes Cell Cycle Progression of Malignant Melanoma by Targeting PTEN. Oncol Rep (2018) 39(1):331-7. doi: 10.3892/or.2017.6099

62. Zhang L, He X, Li F, Pan H, Huang X, Wen X, et al. The miR-181 Family Promotes Cell Cycle by Targeting CTDSPL, a Phosphatase-Like Tumor Suppressor in Uveal Melanoma. J Exp Clin Cancer Res (2018) 37(1):1-13. doi: 10.1186/s13046-018-0679-5

63. Qiu H-J, Lu X-H, Yang S-S, Weng C-Y, Zhang E-K, Chen F-C. MiR-769 Promoted Cell Proliferation in Human Melanoma by Suppressing GSK3B Expression. Biomed Pharmacother (2016) 82:117-23. doi: 10.1016/ j.biopha.2016.04.052

64. Zhou J, Jiang J, Wang S, Xia X. Oncogenic Role of MicroRNA-20a in Human Uveal Melanoma. Mol Med Rep (2016) 14(2):1560-6. doi: 10.3892/ mmr.2016.5433

65. Gaziel-Sovran A, Segura MF, Di Micco R, Collins MK, Hanniford D, de Miera EV-S, et al. miR-30b/30d Regulation of GalNAc Transferases Enhances Invasion and Immunosuppression During Metastasis. Cancer Cell (2011) 20(1):104-18. doi: 10.1016/j.ccr.2011.05.027

66. Knoll S, Fürst K, Kowtharapu B, Schmitz U, Marquardt S, Wolkenhauer O, et al. E2F1 Induces miR-224/452 Expression to Drive EMT Through TXNIP Downregulation. EMBO Rep (2014) 15(12):1315-29. doi: 10.15252/ embr. 201439392

67. Ohira T, Naohiro S, Nakayama Y, Osaki M, Okada F, Oshimura M, et al. miR-19b Regulates HTERT MRNA Expression Through Targeting PITX1 MRNA in Melanoma Cells. Sci Rep (2015) 5(1):1-9. doi: 10.1038/srep08201

68. Lankenau MA, Patel R, Liyanarachchi S, Maharry SE, Hoag KW, Duggan M, et al. MicroRNA-3151 Inactivates TP53 in BRAF-mutated Human Malignancies. Proc Natl Acad Sci (2015) 112(49):E6744-E51. doi: 10.1073/pnas.1520390112

69. Cui L, Li Y, Lv X, Li J, Wang X, Lei Z, et al. Expression of MicroRNA-301a and Its Functional Roles in Malignant Melanoma. Cell Physiol Biochem (2016) 40(1-2):230-44. doi: 10.1159/000452540

70. Zhang D, Li Z, Zhang Y, Tu C, Huo J, Liu Y. miR-4262 Promotes the Proliferation of Human Cutaneous Malignant Melanoma Cells Through KLF6-mediated EGFR Inactivation and p21 Upregulation. Oncol Rep (2016) 36(6):3657-63. doi: 10.3892/or.2016.5190

71. Prasad R, Katiyar SK. Down-Regulation of MiRNA-106b Inhibits Growth of Melanoma Cells by Promoting G1-Phase Cell Cycle Arrest and Reactivation of P21/WAF1/Cip1 Protein. Oncotarget (2014) 5(21):10636. doi: 10.18632/ oncotarget. 2527

72. Hua K-T, Hong J-B, Sheen Y-S, Huang H-Y, Huang Y-L, Chen J-S, et al. miR-519d Promotes Melanoma Progression by Downregulating Epha4. Cancer Res (2018) 78(1):216-29. doi: 10.1158/0008-5472.CAN-17-1933

73. Wei S, Ma W. MiR-370 Functions as Oncogene in Melanoma by Direct Targeting Pyruvate Dehydrogenase B. Biomed Pharmacother (2017) 90:27886. doi: 10.1016/j.biopha.2017.03.068

74. Bai X, Yang M, Xu Y. MicroRNA-373 Promotes Cell Migration Via Targeting Salt-Inducible Kinase 1 Expression in Melanoma. Exp Ther Med (2018) 16(6):4759-64. doi: 10.3892/etm.2018.6784

75. Sun H, Yang G, Wang S, Zhang Y, Ding J, Zhang X. MicroRNA-92a Regulates the Development of Cutaneous Malignant Melanoma by Mediating FOXP1. Eur Rev Med Pharmacol Sci (2019) 23(20):8991-9. doi: 10.26355/eurrev_201910_19299

76. Yang C, Yan Z, Hu F, Wei W, Sun Z, Xu W. Silencing of MicroRNA-517a Induces Oxidative Stress Injury in Melanoma Cells Via Inactivation of the JNK Signaling Pathway by Upregulating CDKN1C. Cancer Cell Int (2020) 20 (1):32. doi: 10.1186/s12935-019-1064-y

77. Tang H, Xu X, Xiao W, Liao Y, Xiao X, Li L, et al. Silencing of MicroRNA27a Facilitates Autophagy and Apoptosis of Melanoma Cells Through the Activation of the SYK-dependent MTOR Signaling Pathway. J Cell Biochem (2019) 120(8):13262-74. doi: 10.1002/jcb.28600

78. Qiu H, Yuan S, Lu X. miR-186 Suppressed CYLD Expression and Promoted Cell Proliferation in Human Melanoma. Oncol Lett (2016) 12(4):2301-6. doi: 10.3892/ol.2016.5002

79. Yu Y, Yu F, Sun P. MicroRNA-1246 Promotes Melanoma Progression Through Targeting Foxa2. OncoTargets Ther (2020) 13:1245. doi: 10.2147/ OTT.S234276
80. Wan J, Yang J, Huang Y, Deng L. MicroRNA-150 Inhibitors Enhance Cell Apoptosis of Melanoma by Targeting PDCD4. Oncol Lett (2018) 15 (2):1475-82. doi: 10.3892/ol.2017.7445

81. Sun M-X, An Q, Chen L-M, Guo L. MIR-520f Regulated Itch Expression and Promoted Cell Proliferation in Human Melanoma Cells. Dose-Response (2020) 18(2):1559325820918450. doi: 10.1177/1559325820918450

82. Wang Z, Liu Y. MicroRNA-633 Enhances Melanoma Cell Proliferation and Migration by Suppressing KAI1. Oncol Lett (2021) 21(2):1-. doi: 10.3892/ ol.2020.12349

83. Yan D, Zhou X, Chen X, Hu D-N, Da Dong X, Wang J, et al. MicroRNA-34a Inhibits Uveal Melanoma Cell Proliferation and Migration Through Downregulation of C-Met. Invest Ophthalmol Visual Sci (2009) 50 (4):1559-65. doi: 10.1167/iovs.08-2681

84. Migliore C, Petrelli A, Ghiso E, Corso S, Capparuccia L, Eramo A, et al. MicroRNAs Impair MET-mediated Invasive Growth. Cancer Res (2008) 68 (24):10128-36. doi: 10.1158/0008-5472.CAN-08-2148

85. Schultz J, Lorenz P, Gross G, Ibrahim S, Kunz M. MicroRNA let-7b Targets Important Cell Cycle Molecules in Malignant Melanoma Cells and Interferes With Anchorage-Independent Growth. Cell Res (2008) 18(5):549-57. doi: $10.1038 / \mathrm{cr} .2008 .45$

86. Müller D, Bosserhoff A-K. Integrin $\beta 3$ Expression is Regulated by let-7a MiRNA in Malignant Melanoma. Oncogene (2008) 27(52):6698-706. doi: 10.1038/onc.2008.282

87. Huang D, Wang F, Wu W, Lian C, Liu E. MicroRNA-429 Inhibits Cancer Cell Proliferation and Migration by Targeting the AKT1 in Melanoma. Cancer Biomark (2019) 26(1):63-8. doi: 10.3233/CBM-190289

88. Sheng H, Guo Y, Cao D, Li X, Zhao Y, Ding H, et al. MiR-429-5p Attenuates the Migration and Invasion of Malignant Melanoma by Targeting LIMK1. Eur Rev Med Pharmacol Sci (2020) 24(5):2625-31. doi: 10.26355/ eurrev_202003_20531

89. Kang K, Zhang J, Zhang X, Chen Z. MicroRNA-326 Inhibits Melanoma Progression by Targeting KRAS and Suppressing the AKT and ERK Signalling Pathways. Oncol Rep (2018) 39(1):401-10. doi: 10.3892/ or.2017.6074

90. Dong F, Lou D. MicroRNA-34b/c Suppresses Uveal Melanoma Cell Proliferation and Migration Through Multiple Targets. Mol Vis (2012) 18:537.

91. Hou Q, Han S, Yang L, Chen S, Chen J, Ma N, et al. The Interplay of MicroRNA-34a, LGR4, EMT-associated Factors, and MMP2 in Regulating Uveal Melanoma Cells. Invest Ophthalmol Visual Sci (2019) 60(13):4503-10. doi: $10.1167 /$ iovs.18-26477

92. Liu R, Xie H, Luo C, Chen Z, Zhou X, Xia K, et al. Identification of FLOT2 as a Novel Target for MicroRNA-34a in Melanoma. J Cancer Res Clin Oncol (2015) 141(6):993-1006. doi: 10.1007/s00432-014-1874-1

93. Greenberg E, Hershkovitz L, Itzhaki O, Hajdu S, Nemlich Y, Ortenberg R, et al. Regulation of Cancer Aggressive Features in Melanoma Cells by Micrornas. PloS One (2011) 6(4):e18936. doi: 10.1371/journal.pone.0018936

94. Yan D, Da Dong X, Chen X, Yao S, Wang L, Wang J, et al. Role of MicroRNA-182 in Posterior Uveal Melanoma: Regulation of Tumor Development Through MITF, BCL2 and Cyclin D2. PloS One (2012) 7(7): e40967. doi: 10.1371/journal.pone.0040967

95. Venza I, Visalli M, Beninati C, Benfatto S, Teti D, Venza M. Il-10ro Expression is Post-Transcriptionally Regulated by miR-15a, miR-185, and miR-211 in Melanoma. BMC Med Genomics (2015) 8(1):1-9. doi: 10.1186/ s12920-015-0156-3

96. Zhu Y, Wen X, Zhao P. MicroRNA-365 Inhibits Cell Growth and Promotes Apoptosis in Melanoma by Targeting BCL2 and Cyclin D1 (CCND1). Med Sci Monit (2018) 24:3679. doi: 10.12659/MSM.909633

97. Bai J, Zhang Z, Li X, Liu H. MicroRNA-365 Inhibits Growth, Invasion and Metastasis of Malignant Melanoma by Targeting NRP1 Expression. Cancer Biomark (2015) 15(5):599-608. doi: 10.3233/CBM-150500

98. Wu J, Li J, Ren J, Zhang D. MicroRNA-485-5p Represses Melanoma Cell Invasion and Proliferation by Suppressing Frizzled7. Biomed Pharmacother (2017) 90:303-10. doi: 10.1016/j.biopha.2017.03.064

99. Zhu Y, H-1 Z, Wang Q-Y, Chen M-J, Liu L-B. Overexpression of MicroRNA612 Restrains the Growth, Invasion, and Tumorigenesis of Melanoma Cells by Targeting Espin. Molec Cells (2018) 41(2):119. doi: 10.14348/ molcells.2018.2235 
100. Giles KM, Brown RA, Ganda C, Podgorny MJ, Candy PA, Wintle LC, et al. MicroRNA-7-5p Inhibits Melanoma Cell Proliferation and Metastasis by Suppressing Rela/NF-kb. Oncotarget (2016) 7(22):31663. doi: 10.18632/ oncotarget. 9421

101. Giles KM, Brown RA, Epis MR, Kalinowski FC, Leedman PJ. MiRNA-7-5p Inhibits Melanoma Cell Migration and Invasion. Biochem Biophys Res Commun (2013) 430(2):706-10. doi: 10.1016/j.bbrc.2012.11.086

102. Sun X, Li J, Sun Y, Zhang Y, Dong L, Shen C, et al. miR-7 Reverses the Resistance to BRAFi in Melanoma by Targeting EGFR/IGF-1R/CRAF and Inhibiting the MAPK and PI3K/AKT Signaling Pathways. Oncotarget (2016) 7(33):53558. doi: 10.18632/oncotarget.10669

103. Zeng HF, Yan S, Wu SF. MicroRNA-153-3p Suppress Cell Proliferation and Invasion by Targeting SNAI1 in Melanoma. Biochem Biophys Res Commun (2017) 487(1):140-5. doi: 10.1016/j.bbrc.2017.04.032

104. Fang W, Fan Y, Fa Z, Xu J, Yu H, Li P, et al. MicroRNA-625 Inhibits Tumorigenicity by Suppressing Proliferation, Migration and Invasion in Malignant Melanoma. Oncotarget (2017) 8(8):13253. doi: 10.18632/ oncotarget. 14710

105. Lu S, Xu Q. MicroRNA-23a Inhibits Melanoma Cell Proliferation, Migration, and Invasion in Mice Through a Negative Feedback Regulation of Sdcbp and the MAPK/ERK Signaling Pathway. IUBMB Life (2019) 71(5):587-600. doi: 10.1002/iub.1979

106. Guo W, Wang H, Yang Y, Guo S, Zhang W, Liu Y, et al. Down-Regulated miR-23a Contributes to the Metastasis of Cutaneous Melanoma by Promoting Autophagy. Theranostics (2017) 7(8):2231. doi: 10.7150/thno.18835

107. Lv R, Yu J, Sun Q. Anti-Angiogenic Role of MicroRNA-23b in Melanoma by Disturbing NF-kb Signaling Pathway Via Targeted Inhibition of NAMPT. Future Oncol (2020) 16(10):541-458. doi: 10.2217/fon-2019-0699

108. Ma M, Dai J, Tang H, Xu T, Yu S, Si L, et al. MicroRNA-23a-3p Inhibits Mucosal Melanoma Growth and Progression Through Targeting Adenylate Cyclase 1 and Attenuating CAMP and MAPK Pathways. Theranostics (2019) 9(4):945. doi: 10.7150/thno.30516

109. Alderman C, Sehlaoui A, Xiao Z, Yang Y. MicroRNA-15a Inhibits the Growth and Invasiveness of Malignant Melanoma and Directly Targets on CDCA4 Gene. Tumor Biol (2016) 37(10):13941-50. doi: 10.1007/s13277-016-5271-z

110. Panza E, Ercolano G, De Cicco P, Armogida C, Scognamiglio G, Botti G, et al. MicroRNA-143-3p Inhibits Growth and Invasiveness of Melanoma Cells by Targeting Cyclooxygenase-2 and Inversely Correlates With Malignant Melanoma Progression. Biochem Pharmacol (2018) 156:52-9. doi: 10.1016/j.bcp.2018.08.008

111. Nabipoorashrafi SA, Shomali N, Sadat-Hatamnezhad L, Mahami-Oskouei M, Mahmoudi J, Sandoghchian Shotorbani B, et al. miR-143 Acts as an Inhibitor of Migration and Proliferation as Well as an Inducer of Apoptosis in Melanoma Cancer Cells in Vitro. IUBMB Life (2020) 72(9):2034-44. doi: 10.1002/iub.2345

112. Lu H-J, Yan J, Jin P-Y, Zheng G-H, Zhang H-L, Bai M, et al. Mechanism of MicroRNA-708 Targeting BAMBI in Cell Proliferation, Migration, and Apoptosis in Mice With Melanoma Via the Wnt and TGF- $\beta$ Signaling Pathways. Technol Cancer Res Treat (2018) 17:1533034618756784. doi: $10.1177 / 1533034618756784$

113. Song X-F, Wang Q-H, Huo R. Effects of MicroRNA-708 on EpithelialMesenchymal Transition, Cell Proliferation and Apoptosis in Melanoma Cells by Targeting LEF1 Through the Wnt Signaling Pathway. Pathol Oncol Res (2019) 25(1):377-89. doi: 10.1007/s12253-017-0334-z

114. Sun M, Wang X, Tu C, Wang S, Qu J, Xiao S. MicroRNA-216b Inhibits Cell Proliferation and Migration in Human Melanoma by Targeting FOXM1 in Vitro and in Vivo. Cell Biol Int (2017) 41(12):1272-82. doi: 10.1002/cbin.10754

115. Liu Y, Huo Y, Wang D, Tai Y, Li J, Pang D, et al. MiR-216a-5p/Hexokinase 2 Axis Regulates Uveal Melanoma Growth Through Modulation of Warburg Effect. Biochem Biophys Res Commun (2018) 501(4):885-92. doi: 10.1016/ j.bbrc.2018.05.069

116. Yang X, Zhao H, Yang J, Ma Y, Liu Z, Li C, et al. MiR-150-5p Regulates Melanoma Proliferation, Invasion and Metastasis Via SIX1-mediated Warburg Effect. Biochem Biophys Res Commun (2019) 515(1):85-91. doi: 10.1016/j.bbrc.2019.05.111

117. Sun X, Zhang C, Cao Y, Liu E. miR-150 Suppresses Tumor Growth in Melanoma Through Downregulation of MYB. Oncol Res (2019) 27(3):317. doi: $10.3727 / 096504018 X 15228863026239$
118. Tembe V, Schramm SJ, Stark MS, Patrick E, Jayaswal V, Tang YH, et al. MicroRNA and MRNA Expression Profiling in Metastatic Melanoma Reveal Associations With BRAF Mutation and Patient Prognosis. Pigment Cell Melanoma Res (2015) 28(3):254-66. doi: 10.1111/pcmr.12343

119. Wang J-J, Li Z-F, Li X-J, Han Z, Zhang L, Liu Z-J. Effects of MicroRNA-136 on Melanoma Cell Proliferation, Apoptosis, and Epithelial-Mesenchymal Transition by Targetting PMEL Through the Wnt Signaling Pathway. Biosci Rep (2017) 37(5):BSR20170743. doi: 10.1042/BSR20170743

120. Prabhakar K, Rodriguez CI, Jayanthy AS, Mikheil DM, Bhasker AI, Perera RJ, et al. Role of miR-214 in Regulation of $\beta$-Catenin and the Malignant Phenotype of Melanoma. Mol Carcinogen (2019) 58(11):1974-84. doi: $10.1002 / \mathrm{mc} .23089$

121. Zhang J, Na S, Liu C, Pan S, Cai J, Qiu J. MicroRNA-125b Suppresses the Epithelial-Mesenchymal Transition and Cell Invasion by Targeting ITGA9 in Melanoma. Tumor Biol (2016) 37(5):5941-9. doi: 10.1007/s13277-015-4409-8

122. Zhang J, Lu L, Xiong Y, Qin W, Zhang Y, Qian Y, et al. MLK 3 Promotes Melanoma Proliferation and Invasion and is a Target of Micro RNA-125b. Clin Exp Dermatol (2014) 39(3):376-84. doi: 10.1111/ced.12286

123. Kappelmann M, Kuphal S, Meister G, Vardimon L, Bosserhoff A. MicroRNA miR-125b Controls Melanoma Progression by Direct Regulation of c-Jun Protein Expression. Oncogene (2013) 32(24):2984-91. doi: 10.1038/ onc.2012.307

124. Essa S, Denzer N, Mahlknecht U, Klein R, Collnot E, Tilgen W, et al. VDR MicroRNA Expression and Epigenetic Silencing of Vitamin D Signaling in Melanoma Cells. J Steroid Biochem Mol Biol (2010) 121(1-2):110-3. doi: 10.1016/j.jsbmb.2010.02.003

125. Sánchez-Sendra B, Martinez-Ciarpaglini C, González-Muñoz JF, Murgui A, Terrádez L, Monteagudo C. Downregulation of Intratumoral Expression of miR-205, miR-200c and miR-125b in Primary Human Cutaneous Melanomas Predicts Shorter Survival. Sci Rep (2018) 8(1):1-14. doi: 10.1038/s41598-018-35317-3

126. Liu S-M, Lin C-H, Lu J, Lin I-Y, Tsai M-S, Chen M-H, et al. miR-596 Modulates Melanoma Growth by Regulating Cell Survival and Death. J Invest Dermatol (2018) 138(4):911-21. doi: 10.1016/j.jid.2017.11.016

127. Yu H, Ma M, Wang X, Zhou Z, Li R, Guo Q. Propofol Suppresses Proliferation, Invasion, and Migration of Human Melanoma Cells Via Regulating MicroRNA-137 and Fibroblast Growth Factor 9. J Cell Physiol (2019) 234(12):23279-88. doi: 10.1002/jcp.28896

128. Yang H, Shen C. MicroRNA-29c Induces G1 Arrest of Melanoma by Targeting CDK6. J BUON (2019) 24:819-25.

129. Arnold J, Engelmann JC, Schneider N, Bosserhoff AK, Kuphal S. miR-488-5p and Its Role in Melanoma. Exp Mol Pathol (2020) 112:104348. doi: 10.1016/ j.yexmp.2019.104348

130. Li N, Ma Y, Ma L, Guan Y, Ma L, Yang D. MicroRNA-488-3p Sensitizes Malignant Melanoma Cells to Cisplatin by Targeting PRKDC. Cell Biol Int (2017) 41(6):622-9. doi: 10.1002/cbin.10765

131. Liu K, Jin J, Rong K, Zhuo L, Li P. MicroRNA-675 Inhibits Cell Proliferation and Invasion in Melanoma by Directly Targeting Metadherin. Mol Med Rep (2018) 17(2):3372-9. doi: 10.3892/mmr.2017.8264

132. Dietrich P, Kuphal S, Spruss T, Hellerbrand C, Bosserhoff AK. Micro RNA622 is a Novel Mediator of Tumorigenicity in Melanoma by Targeting Kirsten Rat Sarcoma. Pigment Cell Melanoma Res (2018) 31(5):614-29. doi: 10.1111/pcmr.12698

133. Shidal C, Singh NP, Nagarkatti P, Nagarkatti M. MicroRNA-92 Expression in CD133+ Melanoma Stem Cells Regulates Immunosuppression in the Tumor Microenvironment Via Integrin-Dependent Activation of Tgf . Cancer Res (2019) 79(14):3622-35. doi: 10.1158/0008-5472.CAN-18-2659

134. Noguchi S, Kumazaki M, Mori T, Baba K, Okuda M, Mizuno T, et al. Analysis of MicroRNA-203 Function in CREB/MITF/RAB27a Pathway: Comparison Between Canine and Human Melanoma Cells. Vet Comp Oncol (2016) 14(4):384-94. doi: 10.1111/vco.12118

135. Chang X, Sun Y, Han S, Zhu W, Zhang H, Lian S. MiR-203 Inhibits Melanoma Invasive and Proliferative Abilities by Targeting the Polycomb Group Gene BMI1. Biochem Biophys Res Commun (2015) 456(1):361-6. doi: 10.1016/j.bbrc.2014.11.087

136. Wang K, Zhang Z-W. Expression of miR-203 is Decreased and Associated With the Prognosis of Melanoma Patients. Int J Clin Exp Pathol (2015) 8 (10):13249. 
137. Noguchi S, Kumazaki M, Yasui Y, Mori T, Yamada N, Akao Y. MicroRNA203 Regulates Melanosome Transport and Tyrosinase Expression in Melanoma Cells by Targeting Kinesin Superfamily Protein 5b. J Invest Dermatol (2014) 134(2):461-9. doi: 10.1038/jid.2013.310

138. Noguchi S, Mori T, Otsuka Y, Yamada N, Yasui Y, Iwasaki J, et al. AntiOncogenic MicroRNA-203 Induces Senescence by Targeting E2F3 Protein in Human Melanoma Cells. J Biol Chem (2012) 287(15):11769-77. doi: 10.1074/jbc.M111.325027

139. Bu P, Yang P. MicroRNA-203 Inhibits Malignant Melanoma Cell Migration by Targeting Versican. Exp Ther Med (2014) 8(1):309-15. doi: 10.3892/ etm. 2014.1708

140. Wu S, Chen H, Han N, Zhang C, Yan H. Long Noncoding RNA PVT1 Silencing Prevents the Development of Uveal Melanoma by Impairing MicroRNA-17-3p-Dependent MDM2 Upregulation. Invest Ophthalmol Visual Sci (2019) 60(14):4904-14. doi: 10.1167/iovs.19-27704

141. Luan W, Zhou Z, Zhu Y, Xia Y, Wang J, Xu B. miR-137 Inhibits Glutamine Catabolism and Growth of Malignant Melanoma by Targeting Glutaminase. Biochem Biophys Res Commun (2018) 495(1):46-52. doi: 10.1016/ j.bbrc.2017.10.152

142. Chen X, Wang J, Shen H, Lu J, Li C, Hu D-N, et al. Epigenetics, MicroRNAs, and Carcinogenesis: Functional Role of MicroRNA-137 in Uveal Melanoma. Invest Ophthalmol Visual Sci (2011) 52(3):1193-9. doi: 10.1167/iovs.10-5272

143. Lv N, Hao S, Luo C, Abukiwan A, Hao Y, Gai F, et al. miR-137 Inhibits Melanoma Cell Proliferation Through Downregulation of GLO1. Sci China Life Sci (2018) 61(5):541-9. doi: 10.1007/s11427-017-9138-9

144. Peres J, Kwesi-Maliepaard EM, Rambow F, Larue L, Prince S. The Tumour Suppressor, miR-137, Inhibits Malignant Melanoma Migration by Targetting the TBX3 Transcription Factor. Cancer Lett (2017) 405:111-9. doi: 10.1016/ j.canlet.2017.07.018

145. Chang X, Zhang H, Lian S, Zhu W. miR-137 Suppresses Tumor Growth of Malignant Melanoma by Targeting Aurora Kinase a. Biochem Biophys Res Commun (2016) 475(3):251-6. doi: 10.1016/j.bbrc.2016.05.090

146. Li N. Low Expression of Mir-137 Predicts Poor Prognosis in Cutaneous Melanoma Patients. Med Sci Monit (2016) 22:140. doi: 10.12659/ MSM. 895207

147. Hao S, Luo C, Abukiwan A, Wang G, He J, Huang L, et al. miR-137 Inhibits Proliferation of Melanoma Cells by Targeting PAK 2. Exp Dermatol (2015) 24(12):947-52. doi: 10.1111/exd.12812

148. Deng Y, Deng H, Bi F, Liu J, Bemis LT, Norris D, et al. MicroRNA-137 Targets Carboxyl-Terminal Binding Protein 1 in Melanoma Cell Lines. Int $J$ Biol Sci (2011) 7(1):133. doi: 10.7150/ijbs.7.133

149. Luo C, Tetteh PW, Merz PR, Dickes E, Abukiwan A, Hotz-Wagenblatt A, et al. miR-137 Inhibits the Invasion of Melanoma Cells Through Downregulation of Multiple Oncogenic Target Genes. J Invest Dermatol (2013) 133(3):768-75. doi: 10.1038/jid.2012.357

150. Qi J, Ww W, Chen W, Lu WY, Shang AQ. Mechanism of miR-137 Regulating Migration and Invasion of Melanoma Cells by Targeting PIK3R3 Gene. J Cell Biochem (2019) 120(5):8393-400. doi: 10.1002/ jcb. 28124

151. Liu E, Sun X, Li J, Zhang C. miR-30a-5p Inhibits the Proliferation, Migration and Invasion of Melanoma Cells by Targeting SOX4. Mol Med Rep (2018) 18(2):2492-8. doi: 10.3892/mmr.2018.9166

152. Wei Y, Du Y, Chen X, Li P, Wang Y, Zang W, et al. Expression Patterns of MicroRNA-218 and Its Potential Functions by Targeting CIP2A and BMI1 Genes in Melanoma. Tumor Biol (2014) 35(8):8007-15. doi: 10.1007/s13277014-2079-6

153. Chen L, Cao Y, Rong D, Wang Y, Cao Y. MicroRNA-605 Functions as a Tumor Suppressor by Targeting INPP4B in Melanoma. Oncol Rep (2017) 38 (2):1276-86. doi: 10.3892/or.2017.5740

154. Xiao Y, Diao Q, Liang Y, Peng Y, Zeng K. MicroRNA-24-1-5p Promotes Malignant Melanoma Cell Autophagy and Apoptosis Via Regulating Ubiquitin D. Mol Med Rep (2017) 16(6):8448-54. doi: 10.3892/ mmr.2017.7614

155. Ge X, Niture S, Lin M, Cagle P, Li PA, Kumar D. MicroRNA-205-5p Inhibits Skin Cancer Cell Proliferation and Increase Drug Sensitivity by Targeting TNFAIP8. Sci Rep (2021) 11(1):1-14. doi: 10.1038/s41598-021-85097-6

156. Valentini V, Zelli V, Gaggiano E, Silvestri V, Rizzolo P, Bucalo A, et al. MiRNAs as Potential Prognostic Biomarkers for Metastasis in Thin and
Thick Primary Cutaneous Melanomas. Anticancer Res (2019) 39(8):4085-93. doi: 10.21873 /anticanres.13566

157. Liu S, Tetzlaff MT, Liu A, Liegl-Atzwanger B, Guo J, Xu X. Loss of MicroRNA-205 Expression is Associated With Melanoma Progression. Lab Invest (2012) 92(7):1084-96. doi: 10.1038/labinvest.2012.62

158. Li Y, Luo J-T, Liu Y-M, Wei W-B. MiRNA-145/miRNA-205 Inhibits Proliferation and Invasion of Uveal Melanoma Cells by Targeting NPR1/ CDC42. Int J Ophthalmol (2020) 13(5):718. doi: 10.18240/ijo.2020.05.04

159. Liu S, Gao G, Yan D, Chen X, Yao X, Guo S, et al. Effects of miR-145-5p Through NRAS on the Cell Proliferation, Apoptosis, Migration, and Invasion in Melanoma by Inhibiting MAPK and PI 3K/AKT Pathways. Cancer Med (2017) 6(4):819-33. doi: 10.1002/cam4.1030

160. Jin C, Wang A, Liu L, Wang G, Li G, Han Z. miR-145-5p Inhibits Tumor Occurrence and Metastasis Through the NF-kb Signaling Pathway by Targeting TLR4 in Malignant Melanoma. J Cell Biochem (2019) 120 (7):11115-26. doi: 10.1002/jcb.28388

161. Yang J-Y, Li Y, Wang Q, Zhou W-J, Yan Y-N, Wei W-B. MicroRNA-145 Suppresses Uveal Melanoma Angiogenesis and Growth by Targeting Neuroblastoma RAS Viral Oncogene Homolog and Vascular Endothelial Growth Factor. Chin Med J (2020) 133(16):1922. doi: 10.1097/ CM9.0000000000000875

162. Cirilo PDR, de Sousa Andrade LN, Corrêa BRS, Qiao M, Furuya TK, Chammas R, et al. MicroRNA-195 Acts as an Anti-Proliferative MiRNA in Human Melanoma Cells by Targeting Prohibitin 1. BMC Cancer (2017) 17 (1):1-12. doi: 10.1186/s12885-017-3721-7

163. Li N, Liu Y, Pang H, Lee D, Zhou Y, Xiao Z. Methylation-Mediated Silencing of MicroRNA-211 Decreases the Sensitivity of Melanoma Cells to Cisplatin. Med Sci Monit (2019) 25:1590. doi: 10.12659/MSM.911862

164. Mazar J, Qi F, Lee B, Marchica J, Govindarajan S, Shelley J, et al. MicroRNA 211 Functions as a Metabolic Switch in Human Melanoma Cells. Mol Cell Biol (2016) 36(7):1090-108. doi: 10.1128/MCB.00762-15

165. Mazar J, DeYoung K, Khaitan D, Meister E, Almodovar A, Goydos J, et al. The Regulation of MiRNA-211 Expression and Its Role in Melanoma Cell Invasiveness. PloS One (2010) 5(11):e13779. doi: 10.1371/ journal.pone.0013779

166. Yu H, Yang W. MiR-211 is Epigenetically Regulated by DNMT1 Mediated Methylation and Inhibits EMT of Melanoma Cells by Targeting RAB22A. Biochem Biophys Res Commun (2016) 476(4):400-5. doi: 10.1016/ j.bbrc.2016.05.133

167. Sakurai E, Maesawa C, Shibazaki M, Yasuhira S, Oikawa H, Sato M, et al. Downregulation of MicroRNA-211 is Involved in Expression of Preferentially Expressed Antigen of Melanoma in Melanoma Cells. Int $J$ Oncol (2011) 39(3):665-72. doi: 10.3892/ijo.2011.1084

168. Boyle GM, Woods SL, Bonazzi VF, Stark MS, Hacker E, Aoude LG, et al. Melanoma Cell Invasiveness is Regulated by miR-211 Suppression of the BRN2 Transcription Factor. Pigment Cell Melanoma Res (2011) 24(3):52537. doi: 10.1111/j.1755-148X.2011.00849.x

169. Bell RE, Khaled M, Netanely D, Schubert S, Golan T, Buxbaum A, et al. Transcription Factor/MicroRNA Axis Blocks Melanoma Invasion Program by miR-211 Targeting NUAK1. J Invest Dermatol (2014) 134(2):441-51. doi: 10.1038/jid.2013.340

170. Levy C, Khaled M, Iliopoulos D, Janas MM, Schubert S, Pinner S, et al. Intronic miR-211 Assumes the Tumor Suppressive Function of Its Host Gene in Melanoma. Mol Cell (2010) 40(5):841-9. doi: 10.1016/ j.molcel.2010.11.020

171. Du M, Zhang Z, Gao T. Piceatannol Induced Apoptosis Through UpRegulation of MicroRNA-181a in Melanoma Cells. Biol Res (2017) 50. doi: 10.1186/s40659-017-0141-8

172. Barbato A, Iuliano A, Volpe M, D'Alterio R, Brillante S, Massa F, et al. Integrated Genomics Identifies Mir-181/TFAM Pathway as a Critical Driver of Drug Resistance in Melanoma. Int J Mol Sci (2021) 22(4):1801. doi: 10.3390/ijms22041801

173. Mazar J, DeBlasio D, Govindarajan SS, Zhang S, Perera RJ. Epigenetic Regulation of MicroRNA-375 and Its Role in Melanoma Development in Humans. FEBS Lett (2011) 585(15):2467-76. doi: 10.1016/j.febslet.2011.06.025

174. Li J-R, Wang J-Q, Gong Q, Fang R-H, Guo Y-L. MicroRNA-328 Inhibits Proliferation of Human Melanoma Cells by Targeting TGFB2. Asian Pac J Cancer Prev (2015) 16(4):1575-9. doi: 10.7314/APJCP.2015.16.4.1575 
175. Zou B, Zhu W, Liu H, Wang S, Zhu H. Identification and Functional Evaluation of miR-4633-5p as a Biomarker and Tumor Suppressor in Metastatic Melanoma. Cell Physiol Biochem (2018) 49(4):1364-79. doi: $10.1159 / 000493414$

176. Wang H, Yu L, Shan X. Expression Levels of MicroRNA-455 and Its Potential Functions by Targeting IGF-1R in Melanoma. Mol Med Rep (2017) 15(6):3852-8. doi: 10.3892/mmr.2017.6468

177. Noguchi S, Mori T, Hoshino Y, Yamada N, Nakagawa T, Sasaki N, et al. Comparative Study of Anti-Oncogenic MicroRNA-145 in Canine and Human Malignant Melanoma. J Vet Med Sci (2011) 74(1):1108090601. doi: 10.1292/jvms.11-0264

178. Yang L, Qiming H, Xuehui S, Xiang J, Li S, Xiaolin X, et al. MicroRNA 145 May Play an Important Role in Uveal Melanoma Cell Growth by Potentially Targeting Insulin Receptor Substrate-1. Chin Med J (2014) 127(8):1410-6. doi: 10.3760/cma.j.issn.0366-6999.20133206

179. Dynoodt P, Speeckaert R, De Wever O, Chevolet I, Brochez L, Lambert J, et al. miR-145 Overexpression Suppresses the Migration and Invasion of Metastatic Melanoma Cells. Int J Oncol (2013) 42(4):1443-51. doi: 10.3892/ ijo.2013.1823

180. Long J, Menggen Q, Wuren Q, Shi Q, Pi X. MiR-219-5p Inhibits the Growth and Metastasis of Malignant Melanoma by Targeting BCL-2. BioMed Res Int (2017) 2017(9032502):7. doi: 10.1155/2017/9032502

181. Asangani IA, Harms PW, Dodson L, Pandhi M, Kunju LP, Maher CA, et al. Genetic and Epigenetic Loss of MicroRNA-31 Leads to Feed-Forward Expression of EZH2 in Melanoma. Oncotarget (2012) 3(9):1011. doi: 10.18632/oncotarget.622

182. Chen X, He D, Da Dong X, Dong F, Wang J, Wang L, et al. MicroRNA-124a is Epigenetically Regulated and Acts as a Tumor Suppressor by Controlling Multiple Targets in Uveal Melanoma. Invest Ophthalmol Visual Sci (2013) 54 (3):2248-56. doi: 10.1167/iovs.12-10977

183. Zhang D, Han Y, Xu L. Upregulation of miR-124 by Physcion 8-O- $\beta$ Glucopyranoside Inhibits Proliferation and Invasion of Malignant Melanoma Cells Via Repressing RLIP76. Biomed Pharmacother (2016) 84:166-76. doi: 10.1016/j.biopha.2016.09.022

184. Yang P, Bu P, Li C. miR-124 Inhibits Proliferation, Migration and Invasion of Malignant Melanoma Cells Via Targeting Versican. Exp Ther Med (2017) 14(4):3555-62. doi: 10.3892/etm.2017.4998

185. Tian R, Liu T, Qiao L, Gao M, Li J. Decreased Serum MicroRNA-206 Level Predicts Unfavorable Prognosis in Patients With Melanoma. Int J Clin Exp Pathol (2015) 8(3):3097.

186. Georgantas RWII, Streicher K, Luo X, Greenlees L, Zhu W, Liu Z, et al. Micro RNA-206 Induces G 1 Arrest in Melanoma by Inhibition of CDK 4 and C Yclin D. Pigment Cell Melanoma Res (2014) 27(2):275-86. doi: 10.1111/ pcmr. 12200

187. Su B-B, Zhou S-W, Gan C-B, Zhang X-N. MiR-186 Inhibits Cell Proliferation and Invasion in Human Cutaneous Malignant Melanoma. J Cancer Res Ther (2018) 14(8):60. doi: 10.4103/0973-1482.157340

188. Li M, Long C, Yang G, Luo Y, Du H. MiR-26b Inhibits Melanoma Cell Proliferation and Enhances Apoptosis by Suppressing TRAF5-mediated MAPK Activation. Biochem Biophys Res Commun (2016) 471(3):361-7. doi: 10.1016/j.bbrc.2016.02.021

189. Mueller DW, Bosserhoff AK. MicroRNA miR-196a Controls MelanomaAssociated Genes by Regulating HOX-C8 Expression. Int J Cancer (2011) 129(5):1064-74. doi: 10.1002/ijc.25768

190. Braig S, Mueller DW, Rothhammer T, Bosserhoff A-K. MicroRNA miR-196a is a Central Regulator of HOX-B7 and BMP4 Expression in Malignant Melanoma. Cell Mol Life Sci (2010) 67(20):3535-48. doi: 10.1007/s00018-010-0394-7

191. Chen J, Feilotter HE, Paré GC, Zhang X, Pemberton JG, Garady C, et al. MicroRNA-193b Represses Cell Proliferation and Regulates Cyclin D1 in Melanoma. Am J Pathol (2010) 176(5):2520-9. doi: 10.2353/ ajpath.2010.091061

192. Chen J, Zhang X, Lentz C, Abi-Daoud M, Paré GC, Yang X, et al. miR-193b Regulates Mcl-1 in Melanoma. Am J Pathol (2011) 179(5):2162-8. doi: 10.1016/j.ajpath.2011.07.010

193. Liu S, Tetzlaff MT, Cui R, Xu X. miR-200c Inhibits Melanoma Progression and Drug Resistance Through Down-Regulation of BMI-1. Am J Pathol (2012) 181(5):1823-35. doi: 10.1016/j.ajpath.2012.07.009
194. Bustos MA, Ono S, Marzese DM, Oyama T, Iida Y, Cheung G, et al. MiR200a Regulates CDK4/6 Inhibitor Effect by Targeting CDK6 in Metastatic Melanoma. J Invest Dermatol (2017) 137(9):1955-64. doi: 10.1016/ j.jid.2017.03.039

195. Chen W, Xu Y, Zhang X. Targeting GOLM1 by MicroRNA-200a in Melanoma Suppresses Cell Proliferation, Invasion and Migration Via Regulating PI3K/Akt Signaling Pathway and Epithelial-Mesenchymal Transition. Eur Rev Med Pharmacol Sci (2019) 23(16):6997-7007. doi: 10.26355/eurrev_201908_18740

196. Peng J, Liu H, Liu C. MiR-155 Promotes Uveal Melanoma Cell Proliferation and Invasion by Regulating NDFIP1 Expression. Technol Cancer Res Treat (2017) 16(6):1160-7. doi: 10.1177/1533034617737923

197. Levati L, Pagani E, Romani S, Castiglia D, Piccinni E, Covaciu C, et al. MicroRNA-155 Targets the SKI Gene in Human Melanoma Cell Lines. Pigment Cell Melanoma Res (2011) 24(3):538-50. doi: 10.1111/j.1755148X.2011.00857.x

198. Li H, Song J, Chen H, Wang Q, Meng L, Li Y. MiR-155 Inhibits Proliferation, Invasion and Migration of Melanoma Via Targeting CBL. Eur Rev Med Pharmacol Sci (2019) 23(21):9525-34. doi: 10.26355/eurrev_201911_19447

199. Dar AA, Majid S, Rittsteuer C, de Semir D, Bezrookove V, Tong S, et al. The Role of miR-18b in MDM2-p53 Pathway Signaling and Melanoma Progression. J Natl Cancer Inst (2013) 105(6):433-42. doi: 10.1093/jnci/ djt003

200. Chen Y, Zhang Z, Luo C, Chen Z, Zhou J. MicroRNA-18b Inhibits the Growth of Malignant Melanoma Via Inhibition of HIF-1 $\alpha$-Mediated Glycolysis. Oncol Rep (2016) 36(1):471-9. doi: 10.3892/or.2016.4824

201. Reuland SN, Smith SM, Bemis LT, Goldstein NB, Almeida AR, Partyka KA, et al. MicroRNA-26a is Strongly Downregulated in Melanoma and Induces Cell Death Through Repression of Silencer of Death Domains (SODD). J Invest Dermatol (2013) 133(5):1286-93. doi: 10.1038/jid.2012.400

202. Fu X, Meng Z, Liang W, Tian Y, Wang X, Han W, et al. miR-26a Enhances MiRNA Biogenesis by Targeting Lin28B and Zcchc11 to Suppress Tumor Growth and Metastasis. Oncogene (2014) 33(34):4296-306. doi: 10.1038/ onc.2013.385

203. Qian H, Yang C, Yang Y. MicroRNA-26a Inhibits the Growth and Invasiveness of Malignant Melanoma and Directly Targets on MITF Gene. Cell Death Discovery (2017) 3(1):1-9. doi: 10.1038/cddiscovery.2017.28

204. Liu S, Kumar SM, Lu H, Liu A, Yang R, Pushparajan A, et al. MicroRNA-9 Up-Regulates E-Cadherin Through Inhibition of NF-kb1-Snaill Pathway in Melanoma. J Pathol (2012) 226(1):61-72. doi: 10.1002/path.2964

205. Zhao G, Li Q, Wang A, Jiao J. YY1 Regulates Melanoma Tumorigenesis Through a miR-9 RYBP Axis. J Exp Clin Cancer Res (2015) 34(1):1-11. doi: 10.1186/s13046-015-0177-y

206. Liu N, Sun Q, Chen J, Li J, Zeng Y, Zhai S, et al. MicroRNA-9 Suppresses Uveal Melanoma Cell Migration and Invasion Through the NF-kb1 Pathway. Oncol Rep (2012) 28(3):961-8. doi: 10.3892/or.2012.1905

207. Xu D, Chen X, He Q, Luo C. MicroRNA-9 Suppresses the Growth, Migration, and Invasion of Malignant Melanoma Cells Via Targeting NRP1. OncoTargets Ther (2016) 9:7047. doi: 10.2147/OTT.S107235

208. Bu P, Luo C, He Q, Yang P, Li X, Xu D. MicroRNA-9 Inhibits the Proliferation and Migration of Malignant Melanoma Cells Via Targeting Sirituin 1. Exp Ther Med (2017) 14(2):931-8. doi: 10.3892/etm.2017.4595

209. Lu N-H, Wei C-Y, Qi F-Z, Gu J-Y. Hsa-let-7b Suppresses Cell Proliferation by Targeting UHRF1 in Melanoma. Cancer Invest (2020) 38(1):52-60. doi: 10.1080/07357907.2019.1709482

210. Zhou Y, Zhang L, Fan J, Jia R, Song X, Xu X, et al. Let-7b Overexpression Leads to Increased Radiosensitivity of Uveal Melanoma Cells. Melanoma Res (2015) 25(2):119-26. doi: 10.1097/CMR.0000000000000140

211. Tang H, Ma M, Dai J, Cui C, Si L, Sheng X, et al. miR-let-7b and miR-let-7c Suppress Tumourigenesis of Human Mucosal Melanoma and Enhance the Sensitivity to Chemotherapy. J Exp Clin Cancer Res (2019) 38(1):1-14. doi: 10.1186/s13046-019-1190-3

212. Yao Y, Zuo J, Wei Y. Targeting of TRX2 by miR-330-3p in Melanoma Inhibits Proliferation. Biomed Pharmacother (2018) 107:1020-9. doi: 10.1016/j.biopha.2018.08.058

213. Su B-B, Zhou S-W, Gan C-B, Zhang X-N. MiR-330-5p Regulates Tyrosinase and PDIA3 Expression and Suppresses Cell Proliferation and Invasion in 
Cutaneous Malignant Melanoma. J Surg Res (2016) 203(2):434-40. doi: 10.1016/j.jss.2016.03.021

214. Sun Y, Cheng H, Wang G, Yu G, Zhang D, Wang Y, et al. Deregulation of miR-183 Promotes Melanoma Development Via LncRNA MALAT1 Regulation and ITGB1 Signal Activation. Oncotarget (2017) 8(2):3509. doi: 10.18632/oncotarget.13862

215. Sun L, Bian G, Meng Z, Dang G, Shi D, Mi S. MiR-144 Inhibits Uveal Melanoma Cell Proliferation and Invasion by Regulating c-Met Expression. PloS One (2015) 10(5):e0124428. doi: 10.1371/journal.pone.0124428

216. Amaro A, Croce M, Ferrini S, Barisione G, Gualco M, Perri P, et al. Potential Onco-Suppressive Role of miR122 and miR144 in Uveal Melanoma Through ADAM10 and C-Met Inhibition. Cancers (2020) 12(6):1468. doi: 10.3390/ cancers 12061468

217. Zhao G, Wei Z, Guo Y. MicroRNA-107 is a Novel Tumor Suppressor Targeting POU3F2 in Melanoma. Biol Res (2020) 53(1):1-10. doi: 10.1186/ s40659-020-00278-3

218. Wang X, Hu Y, Cui J, Zhou Y, Chen L. Coordinated Targeting of MMP-2/ MMP-9 by Mir-296-3p/FOXCUT Exerts Tumor-Suppressing Effects in Choroidal Malignant Melanoma. Mol Cell Biochem (2018) 445(1):25-33. doi: 10.1007/s11010-017-3248-x

219. Rang Z, Yang G, Y-w W, Cui F. miR-542-3p Suppresses Invasion and Metastasis by Targeting the Proto-Oncogene Serine/Threonine Protein Kinase, PIM1, in Melanoma. Biochem Biophys Res Commun (2016) 474 (2):315-20. doi: 10.1016/j.bbrc.2016.04.093

220. Zhang H, Feng C, Zhang M, Zeng A, Si L, Yu N, et al. Mir-625-5p/PKM2 Negatively Regulates Melanoma Glycolysis State. J Cell Biochem (2019) 120 (3):2964-72. doi: 10.1002/jcb.26917

221. Weber CE, Luo C, Hotz-Wagenblatt A, Gardyan A, Kordaß T, Holland-Letz T, et al. miR-339-3p is a Tumor Suppressor in Melanoma. Cancer Res (2016) 76(12):3562-71. doi: 10.1158/0008-5472.CAN-15-2932

222. Mou K, Ding M, Han D, Zhou Y, Mu X, Liu W, et al. miR-590-5p Inhibits Tumor Growth in Malignant Melanoma by Suppressing YAP1 Expression. Oncol Rep (2018) 40(4):2056-66. doi: 10.3892/or.2018.6633

223. Jiang C, Croft A, Tseng H, Guo S, Jin L, Hersey P, et al. Repression of MicroRNA-768-3p by MEK/ERK Signalling Contributes to Enhanced MRNA Translation in Human Melanoma. Oncogene (2014) 33(20):257788. doi: 10.1038/onc.2013.237

224. Babapoor S, Fleming E, Wu R, Dadras SS. A Novel miR-451a isomiR, Associated With Amelanotypic Phenotype, Acts as a Tumor Suppressor in Melanoma by Retarding Cell Migration and Invasion. PloS One (2014) 9(9): e107502. doi: 10.1371/journal.pone.0107502

225. Mishra PJ, Mishra PJ, Merlino G. Integrated Genomics Identifies Mir-32/ MCL-1 Pathway as a Critical Driver of Melanomagenesis: Implications for miR-replacement and Combination Therapy. PloS One (2016) 11(11): e0165102. doi: 10.1371/journal.pone.0165102

226. Cui A, Jin Z, Gao Z, Jin M, Zhu L, Li L, et al. Downregulation of miR-493 Promoted Melanoma Proliferation by Suppressing IRS4 Expression. Tumor Biol (2017) 39(5):1010428317701640. doi: 10.1177/1010428317701640

227. Hanniford D, Segura MF, Zhong J, Philips E, Jirau-Serrano X, Darvishian F, et al. Identification of Metastasis-Suppressive MicroRNAs in Primary Melanoma. J Natl Cancer Inst (2015) 107(3):dju494. doi: 10.1093/jnci/dju494

228. Guo B, Hui Q, Zhang Y, Chang P, Tao K. miR-194 is a Negative Regulator of GEF-H1 Pathway in Melanoma. Oncol Rep (2016) 36(4):2412-20. doi: 10.3892/or.2016.5020

229. Bai M, Zhang M, Long F, Yu N, Zeng A, Zhao R. Circulating MicroRNA-194 Regulates Human Melanoma Cells Via PI3K/AKT/FoxO3a and p53/p21 Signaling Pathway. Oncol Rep (2017) 37(5):2702-10. doi: 10.3892/ or.2017.5537

230. Song H, Tao Y, Ni N, Zhou X, Xiong J, Zeng X, et al. miR-128 Targets the CC Chemokine Ligand 18 Gene (CCL18) in Cutaneous Malignant Melanoma Progression. J Dermatol Sci (2018) 91(3):317-24. doi: 10.1016/ j.jdermsci.2018.06.011

231. Sun V, Zhou WB, Nosrati M, Majid S, Thummala S, De Semir D, et al. Antitumor Activity of miR-1280 in Melanoma by Regulation of Src. Mol Ther (2015) 23(1):71-8. doi: 10.1038/mt.2014.176

232. Wang H-F, Chen H, Ma M-W, Wang J-A, Tang T-T, Ni L-S, et al. miR-573 Regulates Melanoma Progression by Targeting the Melanoma Cell Adhesion Molecule. Oncol Rep (2013) 30(1):520-6. doi: 10.3892/or.2013.2451
233. Zhang Z, Yang N. MiR-33a-5p Inhibits the Growth and Metastasis of Melanoma Cells by Targeting SNAI2. Neoplasma (2020) 67(4):813-24. doi: 10.4149/neo_2020_190823N811

234. Cao K, Li J, Chen J, Qian L, Wang A, Chen X, et al. MicroRNA-33a-5p Increases Radiosensitivity by Inhibiting Glycolysis in Melanoma. Oncotarget (2017) 8(48):83660. doi: 10.18632/oncotarget.19014

235. Zhou J, Xu D, Xie H, Tang J, Liu R, Li J, et al. miR-33a Functions as a Tumor Suppressor in Melanoma by Targeting HIF-1 $\alpha$. Cancer Biol Ther (2015) 16 (6):846-55. doi: 10.1080/15384047.2015.1030545

236. Tian F, Wei H, Tian H, Qiu Y, Xu J. miR-33a is Downregulated in Melanoma Cells and Modulates Cell Proliferation by Targeting PCTAIRE1. Oncol Lett (2016) 11(4):2741-6. doi: 10.3892/ol.2016.4321

237. Zhao Y, Wu C, Li L. MicroRNA-33b Inhibits Cell Proliferation and Glycolysis by Targeting Hypoxia-Inducible Factor- $1 \alpha$ in Malignant Melanoma. Exp Ther Med (2017) 14(2):1299-306. doi: 10.3892/etm.2017.4702

238. Li F, Li X-J, Qiao L, Shi F, Liu W, Li Y, et al. miR-98 Suppresses Melanoma Metastasis Through a Negative Feedback Loop With Its Target Gene IL-6. Exp Mol Med (2014) 46(10):e116-e. doi: 10.1038/emm.2014.63

239. Liu P, Hu Y, Ma L, Du M, Xia L, Hu Z. miR-425 Inhibits Melanoma Metastasis Through Repression of PI3K-Akt Pathway by Targeting IGF-1. Biomed Pharmacother (2015) 75:51-7. doi: 10.1016/j.biopha.2015.08.010

240. Xiao W, Yao E, Zheng W, Tian F, Tian L. miR-337 Can be a Key Negative Regulator in Melanoma. Cancer Biol Ther (2017) 18(6):392-9. doi: 10.1080/ 15384047.2017.1323581

241. Zhang J, Liu W-L, Zhang L, Ge R, He F, Gao T-Y, et al. MiR-637 Suppresses Melanoma Progression Through Directly Targeting P-REX2a and Inhibiting PTEN/AKT Signaling Pathway. Cell Mol Biol (2018) 64(11):50-7. doi: $10.14715 / \mathrm{cmb} / 2018.64 .11 .10$

242. Mo Y, Fang RH, Wu J, Si Y, Jia SQ, Li Q, et al. MicroRNA-329 Upregulation Impairs the HMGB2/ $\beta$-Catenin Pathway and Regulates Cell Biological Behaviors in Melanoma. J Cell Physiol (2019) 234(12):23518-27. doi: $10.1002 /$ jcp. 28920

243. Fattore L, Mancini R, Acunzo M, Romano G, Laganà $\mathrm{A}$, Pisanu ME, et al. miR-579-3p Controls Melanoma Progression and Resistance to Target Therapy. Proc Natl Acad Sci (2016) 113(34):E5005-13. doi: 10.1073/ pnas. 1607753113

244. Luo C, Merz PR, Chen Y, Dickes E, Pscherer A, Schadendorf D, et al. MiR101 Inhibits Melanoma Cell Invasion and Proliferation by Targeting MITF and EZH2. Cancer Lett (2013) 341(2):240-7. doi: 10.1016/ j.canlet.2013.08.021

245. Ding Z, Jian S, Peng X, Liu Y, Wang J, Zheng L, et al. Loss of MiR-664 Expression Enhances Cutaneous Malignant Melanoma Proliferation by Upregulating PLP2. Medicine (2015) 94(33):e1327. doi: 10.1097/ MD.0000000000001327

246. Xiong Y, Liu L, Qiu Y, Liu L. MicroRNA-29a Inhibits Growth, Migration and Invasion of Melanoma A375 Cells in Vitro by Directly Targeting BMI1. Cell Physiol Biochem (2018) 50(1):385-97. doi: 10.1159/000494015

247. Liu S-M, Lu J, Lee H-C, Chung F-H, Ma N. miR-524-5p Suppresses the Growth of Oncogenic BRAF Melanoma by Targeting BRAF and ERK2. Oncotarget (2014) 5(19):9444. doi: 10.18632/oncotarget.2452

248. Meng F, Zhang Y, Li X, Wang J, Wang Z. Clinical Significance of miR-138 in Patients With Malignant Melanoma Through Targeting of PDK1 in the PI3K/AKT Autophagy Signaling Pathway. Oncol Rep (2017) 38(3):1655-62. doi: 10.3892/or.2017.5838

249. Chen Y, Cao K, Wang S, Chen J, He B, He G, et al. MicroRNA-138 Suppresses Proliferation, Invasion and Glycolysis in Malignant Melanoma Cells by Targeting HIF-1 $\alpha$. Exp Ther Med (2016) 11(6):2513-8. doi: 10.3892/ etm.2016.3220

250. Qiu H, Chen F, Chen M. MicroRNA-138 Negatively Regulates the HypoxiaInducible Factor $1 \alpha$ to Suppress Melanoma Growth and Metastasis. Biol Open (2019) 8(8). doi: 10.1242/bio.042937

251. Lin N, Zhou Y, Lian X, Tu Y. Down-Regulation of Tissue MicroRNA-126 was Associated With Poor Prognosis in Patients With Cutaneous Melanoma. Int J Clin Exp Med (2015) 8(3):4297.

252. Felli N, Felicetti F, Lustri AM, Errico MC, Bottero L, Cannistraci A, et al. miR-126\&126* Restored Expressions Play a Tumor Suppressor Role by Directly Regulating ADAM9 and MMP7 in Melanoma. PloS One (2013) 8 (2):e56824. doi: 10.1371/journal.pone.0056824 
253. Zehavi L, Schayek H, Jacob-Hirsch J, Sidi Y, Leibowitz-Amit R, Avni D. MiR377 Targets E2F3 and Alters the NF-kB Signaling Pathway Through MAP3K7 in Malignant Melanoma. Mol Cancer (2015) 14(1):1-16. doi: 10.1186/s12943-015-0338-9

254. Yang C, Xia Z, Zhu L, Li Y, Zheng Z, Liang J, et al. MicroRNA-139-5p Modulates the Growth and Metastasis of Malignant Melanoma Cells Via the PI3K/AKT Signaling Pathway by Binding to IGF1R. Cell Cycle (2019) 18 (24):3513-24. doi: 10.1080/15384101.2019.1690881

255. Shi Q, He Q, Wei J. MicroRNA-342 Prohibits Proliferation and Invasion of Melanoma Cells by Directly Targeting Zinc-Finger E-Box-Binding Homeobox 1. Oncol Res (2018) 26(9):1447. doi: 10.3727/ 096504018X15193823766141

256. Tian P, Tao L, Wang Y, Han X. MicroRNA-127 Inhibits the Progression of Melanoma by Downregulating Delta-Like Homologue 1. BioMed Res Int (2020) 2020(8523465):10. doi: 10.1155/2020/8523465

257. Shi L, Huo J, Chen S, Xue J, Gao W, Li X, et al. MicroRNA-22 Targets FMNL2 to Inhibit Melanoma Progression Via the Regulation of the Wnt/ $\beta$ Catenin Signaling Pathway and Epithelial-Mesenchymal Transition. Eur Rev Med Pharmacol Sci (2019) 23(12):5332-42. doi: 10.26355/ eurrev_201906_18200

258. Palkina N, Komina A, Aksenenko M, Moshev A, Savchenko A, Ruksha T. miR-204-5p and miR-3065-5p Exert Antitumor Effects on Melanoma Cells. Oncol Lett (2018) 15(6):8269-80. doi: 10.3892/ol.2018.8443

259. Luan W, Qian Y, Ni X, Bu X, Xia Y, Wang J, et al. miR-204-5p Acts as a Tumor Suppressor by Targeting Matrix Metalloproteinases-9 and B-Cell Lymphoma-2 in Malignant Melanoma. OncoTargets Ther (2017) 10:1237. doi: $10.2147 / O T T . S 128819$

260. Zhang G, Ai D, Yang X, Ji S, Wang Z, Feng S. MicroRNA-610 Inhibits Tumor Growth of Melanoma by Targeting LRP6. Oncotarget (2017) 8 (57):97361. doi: 10.18632/oncotarget.22125

261. Zhu L, Liu Z, Dong R, Wang X, Zhang M, Guo X, et al. MicroRNA-3662 Targets ZEB1 and Attenuates the Invasion of the Highly Aggressive Melanoma Cell Line A375. Cancer Manage Res (2019) 11:5845. doi: 10.2147/CMAR.S200540

262. Chen L, Ma G, Cao X, An X, Liu X. MicroRNA-331 Inhibits Proliferation and Invasion of Melanoma Cells by Targeting Astrocyte-Elevated gene-1. Oncol Res (2018) 26(9):1429. doi: 10.3727/096504018X15186047251584

263. Chen W, Zhang J, Xu H, Dai J, Zhang X. The Negative Regulation of miR149-5p in Melanoma Cell Survival and Apoptosis by Targeting LRIG2. Am J Trans Res (2017) 9(9):4331.

264. Zhang C, Li H, Wang J, Zhang J, Hou X. MicroRNA-338-3p Suppresses Cell Proliferation, Migration and Invasion in Human Malignant Melanoma by Targeting MACC1. Exp Ther Med (2019) 18(2):997-1004. doi: 10.3892/ etm.2019.7644

265. Zhou H, Rao Y, Sun Q, Liu Y, Zhou X, Chen Y, et al. MiR-4458/human Antigen R (HuR) Modulates PBX3 MRNA Stability in Melanoma Tumorigenesis. Arch Dermatol Res (2020) 312:665-73. doi: 10.1007/ s00403-020-02051-8

266. Yang X, Zhu X, Yan Z, Li C, Zhao H, Ma L, et al. Mir-489-3p/SIX1 Axis Regulates Melanoma Proliferation and Glycolytic Potential. Mol TherOncolyt (2020) 16:30-40. doi: 10.1016/j.omto.2019.11.001

267. Sun Y, Li X, Wang H, Wu J. MiR-431 is a Prognostic Marker and Suppresses Cell Growth, Migration and Invasion by Targeting NOTCH2 in Melanoma. Eur Rev Med Pharmacol Sci (2019) 23(9):3876-84. doi: 10.26355/ eurrev_201905_17815

268. Li Y, Fu Y, Gao Y, Li H, Ma L, Shu C, et al. MicroRNA-134 Inhibits Melanoma Growth and Metastasis by Negatively Regulating Collagen Triple Helix Repeat Containing-1 (CTHRC1). Int J Clin Exp Pathol (2018) 11 (9):4319.

269. Li J, Liu X, Li C, Wang W. miR-224-5p Inhibits Proliferation, Migration, and Invasion by Targeting PIK3R3/AKT3 in Uveal Melanoma. J Cell Biochem (2019) 120(8):12412-21. doi: 10.1002/jcb.28507

270. Zhao G, Yin Y, Zhao B. miR-140-5p is Negatively Correlated With Proliferation, Invasion, and Tumorigenesis in Malignant Melanoma by Targeting SOX4 Via the Wnt/ $\beta$-Catenin and NF- $\kappa b$ Cascades. J Cell Physiol (2020) 235(3):2161-70. doi: 10.1002/jcp.29122

271. He Y, Yang Y, Liao Y, Xu J, Liu L, Li C, et al. miR-140-3p Inhibits Cutaneous Melanoma Progression by Disrupting AKT/p70S6K and JNK Pathways
Through ABHD2. Mol Ther-Oncolyt (2020) 17:83-93. doi: 10.1016/ j.omto.2020.03.009

272. Zhang X, Xin Z. MiR-135b-5p Inhibits the Progression of Malignant Melanoma Cells by Targeting RBX1. Eur Rev Med Pharmacol Sci (2020) 24(3):1309-15. doi: 10.21203/rs.3.rs-16546/v3

273. Hanniford D, Zhong J, Koetz L, Gaziel-Sovran A, Lackaye DJ, Shang S, et al. A MiRNA-based Signature Detected in Primary Melanoma Tissue Predicts Development of Brain Metastasis. Clin Cancer Res (2015) 21(21):4903-12. doi: 10.1158/1078-0432.CCR-14-2566

274. Worley LA, Long MD, Onken MD, Harbour JW. Micro-RNAs Associated With Metastasis in Uveal Melanoma Identified by Multiplexed Microarray Profiling. Melanoma Res (2008) 18(3):184-90. doi: 10.1097/ CMR.0b013e3282feeac6

275. Bai M, Zhang H, Si L, Yu N, Zeng A, Zhao R. Upregulation of Serum miR$10 \mathrm{~b}$ is Associated With Poor Prognosis in Patients With Melanoma. J Cancer (2017) 8(13):2487. doi: 10.7150/jca.18824

276. Caramuta S, Egyházi S, Rodolfo M, Witten D, Hansson J, Larsson C, et al. MicroRNA Expression Profiles Associated With Mutational Status and Survival in Malignant Melanoma. J Invest Dermatol (2010) 130(8):206270. doi: $10.1038 /$ jid.2010.63

277. Falzone L, Romano GL, Salemi R, Bucolo C, Tomasello B, Lupo G, et al. Prognostic Significance of Deregulated MicroRNAs in Uveal Melanomas. Mol Med Rep (2019) 19(4):2599-610. doi: 10.3892/mmr.2019.9949

278. Segura MF, Belitskaya-Lévy I, Rose AE, Zakrzewski J, Gaziel A, Hanniford D, et al. Melanoma MicroRNA Signature Predicts Post-Recurrence Survival. Clin Cancer Res (2010) 16(5):1577-86. doi: 10.1158/1078-0432.CCR-09-2721

279. Nguyen T, Kuo C, Nicholl MB, Sim M-S, Turner RR, Morton DL, et al. Downregulation of MicroRNA-29c is Associated With Hypermethylation of Tumor-Related Genes and Disease Outcome in Cutaneous Melanoma. Epigenetics (2011) 6(3):388-94. doi: 10.4161/epi.6.3.14056

280. Hanna JA, Hahn L, Agarwal S, Rimm DL. In Situ Measurement of miR-205 in Malignant Melanoma Tissue Supports Its Role as a Tumor Suppressor Microrna. Lab Invest (2012) 92(10):1390-7. doi: 10.1038/labinvest.2012.119

281. Yan J, Jiang Q, Lu H, Na S, Long S, Xin Y, et al. Association Between MicroRNA-125b Expression in Formalin-Fixed Paraffin-Embedded Tumor Tissues and Prognosis in Patients With Melanoma. Oncol Lett (2019) 18(2):1856-62. doi: 10.3892/ol.2019.10506

282. Kozubek J, Ma Z, Fleming E, Duggan T, Wu R, Shin D-G, et al. In-Depth Characterization of MicroRNA Transcriptome in Melanoma. PloS One (2013) 8(9):e72699. doi: 10.1371/journal.pone.0072699

283. Babapoor S, Horwich M, Wu R, Levinson S, Gandhi M, Makkar H, et al. MicroRNA in Situ Hybridization for miR-211 Detection as an Ancillary Test in Melanoma Diagnosis. Modern Pathol (2016) 29(5):461-75. doi: 10.1038/ modpathol.2016.44

284. Tengda L, Shuping L, Mingli G, Jie G, Yun L, Weiwei Z, et al. Serum Exosomal MicroRNAs as Potent Circulating Biomarkers for Melanoma. Melanoma Res (2018) 28(4):295-303. doi: 10.1097/CMR.0000000000000450

285. Fogli S, Polini B, Carpi S, Pardini B, Naccarati A, Dubbini N, et al. Identification of Plasma MicroRNAs as New Potential Biomarkers With High Diagnostic Power in Human Cutaneous Melanoma. Tumor Biol (2017) 39(5):1010428317701646. doi: 10.1177/1010428317701646

286. Leidinger P, Keller A, Borries A, Reichrath J, Rass K, Jager SU, et al. HighThroughput MiRNA Profiling of Human Melanoma Blood Samples. BMC Cancer (2010) 10(1):1-11. doi: 10.1186/1471-2407-10-262

287. Stark MS, Gray ES, Isaacs T, Chen FK, Millward M, McEvoy A, et al. A Panel of Circulating MicroRNAs Detects Uveal Melanoma With High Precision. Trans Vision Sci Technol (2019) 8(6):12-. doi: 10.1167/tvst.8.6.12

288. Armand-Labit V, Meyer N, Casanova A, Bonnabau H, Platzer V, Tournier E, et al. Identification of a Circulating MicroRNA Profile as a Biomarker of Metastatic Cutaneous Melanoma. Acta Dermato-Venereolog (2016) 96 (1):29-34. doi: 10.2340/00015555-2156

289. Shiiyama R, Fukushima S, Jinnin M, Yamashita J, Miyashita A, Nakahara S, et al. Sensitive Detection of Melanoma Metastasis Using Circulating MicroRNA Expression Profiles. Melanoma Res (2013) 23(5):366-72. doi: 10.1097/CMR.0b013e328363e485

290. Xin X, Zhang Y, Ling F, Wang L, Sheng X, Qin L, et al. Identification of a Nine-MiRNA Signature for the Prognosis of Uveal Melanoma. Exp Eye Res (2019) 180:242-9. doi: 10.1016/j.exer.2019.01.004 
291. Sun Q, Cong R, Yan H, Gu H, Zeng Y, Liu N, et al. Genistein Inhibits Growth of Human Uveal Melanoma Cells and Affects MicroRNA-27a and Target Gene Expression. Oncol Rep (2009) 22(3):563-7. doi: 10.3892/or_00000472

292. Galore-Haskel G, Nemlich Y, Greenberg E, Ashkenazi S, Hakim M, Itzhaki O, et al. A Novel Immune Resistance Mechanism of Melanoma Cells Controlled by the ADAR1 Enzyme. Oncotarget (2015) 6(30):28999. doi: 10.18632/oncotarget.4905

293. Varrone F, Caputo E. The MiRNAs Role in Melanoma and in Its Resistance to Therapy. Int J Mol Sci (2020) 21(3):878. doi: 10.3390/ijms21030878

294. Gomez-Lira M, Ferronato S, Orlandi E, Dal Molin A, Malerba G, Frigerio S, et al. Association of Micro RNA 146a Polymorphism rs2910164 and the Risk of Melanoma in an Italian Population. Exp Dermatol (2015) 24(10):794-5. doi: $10.1111 /$ exd.12778

295. Sangalli A, Orlandi E, Poli A, Maurichi A, Santinami M, Nicolis M, et al. SexSpecific Effect of RNASEL rs486907 and miR-146a rs2910164 Polymorphisms' Interaction as a Susceptibility Factor for Melanoma Skin Cancer. Melanoma Res (2017) 27(4):309-14. doi: 10.1097/CMR.0000000000000360

296. Yamashita J, Iwakiri T, Fukushima S, Jinnin M, Miyashita A, Hamasaki T, et al. The rs2910164 G>C Polymorphism in MicroRNA-146a is Associated With the Incidence of Malignant Melanoma. Melanoma Res (2013) 23 (1):13-20. doi: 10.1097/CMR.0b013e32835c5b30

297. Lodygin D, Tarasov V, Epanchintsev A, Berking C, Knyazeva T, Körner H, et al. Inactivation of miR-34a by Aberrant CpG Methylation in Multiple Types of Cancer. Cell Cycle (2008) 7(16):2591-600. doi: 10.4161/cc.7.16.6533
298. Ozsolak F, Poling LL, Wang Z, Liu H, Liu XS, Roeder RG, et al. Chromatin Structure Analyses Identify MiRNA Promoters. Genes Dev (2008) 22 (22):3172-83. doi: 10.1101/gad.1706508

299. Syed D N, Imran Khan M, Shabbir M, Mukhtar H. MicroRNAs in Skin Response to UV Radiation. Curr Drug Targets (2013) 14(10):1128-34. doi: 10.2174/13894501113149990184

300. Bemis LT, Chen R, Amato CM, Classen EH, Robinson SE, Coffey DG, et al. MicroRNA-137 Targets Microphthalmia-Associated Transcription Factor in Melanoma Cell Lines. Cancer Res (2008) 68(5):1362-8. doi: 10.1158/00085472.CAN-07-2912

301. Gajos-Michniewicz A, Czyz M. Role of MiRNAs in Melanoma Metastasis. Cancers (2019) 11(3):326. doi: 10.3390/cancers11030326

Conflict of Interest: The authors declare that the research was conducted in the absence of any commercial or financial relationships that could be construed as a potential conflict of interest.

Copyright (c) 2021 Ghafouri-Fard, Gholipour and Taheri. This is an open-access article distributed under the terms of the Creative Commons Attribution License (CC BY). The use, distribution or reproduction in other forums is permitted, provided the original author(s) and the copyright owner(s) are credited and that the original publication in this journal is cited, in accordance with accepted academic practice. No use, distribution or reproduction is permitted which does not comply with these terms. 